\title{
A Study of the Vegetation of Southeastern Washington and Adjacent Idaho
}

A Thesis Presented in Partial Fulfillment of the REQUiREMENTS FOR THE DEgReE OF DOCTOR OF Philosophy

BY

\section{JOHN ERNEST WEAVER}

Submitted to the Graduate Faculty of the University of Minnesota.

LINCOLN, NEBRASKA.

JANUARY, I9I7. 


\title{
A STUDY OF THE VEGETATION OF SOUTHEASTERN WASHINGTON AND ADJACENT IDAHO
}

\author{
BY J. E. WEAVER
}

\section{TABLE OF CONTENTS}

Introduction

PAGE

Extent and position of are:

and geology

Soils .............................................. 6

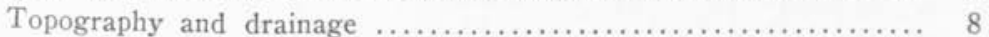

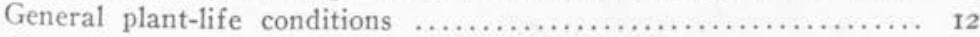

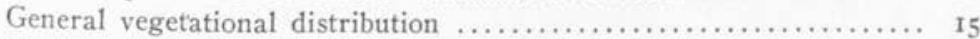

Outline of developmental series $\ldots \ldots \ldots \ldots \ldots \ldots \ldots \ldots \ldots \ldots \ldots \ldots \ldots$ ig

Evaporation and soil moisture in relation to succession $\ldots \ldots \ldots \ldots \ldots$ 2I

Soil temperature in relation to succession $\ldots \ldots \ldots \ldots \ldots \ldots \ldots \ldots, 37$

The prairie-plains formation $\ldots \ldots \ldots \ldots \ldots \ldots \ldots \ldots \ldots \ldots \ldots, 40$

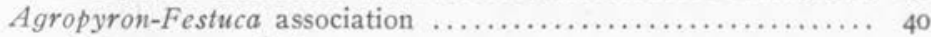

Festuca consociation $\ldots \ldots \ldots \ldots \ldots \ldots \ldots \ldots \ldots \ldots \ldots \ldots, 42$

Agropyron consociation ........................... 59

Rhizocarpon-Lecidea associes .......................63

Gyrophora-Parmelia associes .........................65

Grimmia-Tortula associes ........................ 65

Poa-Polygonum associes ......................... 66

The desert scrub formation $\ldots \ldots \ldots \ldots \ldots \ldots \ldots \ldots \ldots \ldots \ldots, 71_{1}$

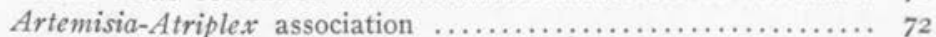

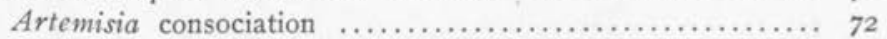

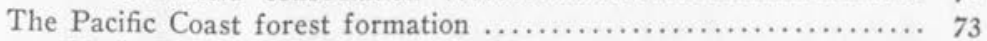

Thuja-T suga association ............................. 74

Symphoricarpos-Opulaster associes ............... 75

Pinus-Pseudotsuga associes ...................... 78

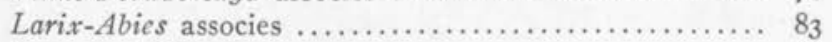

Thuja consociation ............................ 88

Reprinted from University Studies, Vol. XVII., No, I, January, I9I7. 
Adsere. Alnus-Salix associes ....................... 90

Subsere. Natural reforestation in cut-over areas and in burns ...... 91

Hydrosere ....................... 100

Chara-Potamogeton associes ................... I0I

Nymphaea-Potamogeton associes ................. 102

Scirpus-Typha associes ........................ 103

Eleocharis-Carex associes .................... I04

Wet meadow associes ......................... 105

Flood-plain forest associes $\ldots \ldots \ldots \ldots \ldots \ldots \ldots \ldots \ldots$. 07

Ruderal vegetation $\ldots \ldots \ldots \ldots \ldots \ldots \ldots$. 109

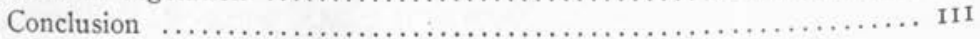

\section{INTRODUCTION}

No one at all botanically inclined can travel through southeastern Washington without being impressed with the marked changes which a distance of only a few miles may show in the vegetation. Traveling eastward from a point fifty miles west of the Idaho state line, one passes from a region of scab-land sagebrush through one of rolling hills covered with bunch-grasses. Upon steadily ascending the great Columbia Plateau, the bunchgrasses give way to well developed prairies, and these in turn, near the Idaho line, to forests of yellow pine, Douglas fir, white fir, tamarack, and cedar. Or starting from Spokane in the central part of eastern Washington and traveling southward, one soon leaves the pine woodland of the Spokane gravels and passes again through the rolling prairies. Projecting above the surrounding sea of prairie-covered basalt are islands of quartzite, the tops of lofty mountains almost buried under the basalt. These may be covered with grass land on the windward side, while at a distance of a few meters over the crest the prairie may give way to rather dense forests. Cut through the layers of basalt, in a mighty canyon, I,600 feet deep, the Snake River winds its way through the prairie belt. Upon descending into the canyon one finds the bunch-grasses and sagebrush vegetation growing in a climate markedly different from that of the plateau above. Far southward from the canyon of the Snake River rise the pine-covered foothills of the Blue Mountains.

Such is a brief glance at the wonderful field for investigation 
offered the ecologist in southeastern Washington. It is a field in which many stages in succession are offered within relatively easy reach of a base station and one in which the vegetation so clearly reveals adjustment to climatic and edaphic conditions that one could scarcely wish for a better place in which to measure the factors of the habitat and the vegetational responses. Moreover, in this great inland province, practically no botanical work except of a taxonomic character has been done $(3,9$, IO, II $)$.

Because of the high fertility of the deep basaltic soils, the prairie region has largely been broken up for the growing of wheat. Indeed, only isolated tracts of the best developed prairies remain intact, while hundreds of acres of the drier bunch-grass lands have been broken up during the time of the progress of this work. It seemed unfortunate that a record of the rapidly disappearing vegetation of this interesting region had not been made. Accordingly, early in the spring of 1912, reconnaissance work was begun, with Pullman, Washington, as the base station.

Ecological work was pursued vigorously in season and out (with the exception of the summer of I9I2) until the fall of I9I4.

In the course of this investigation I have become indebted to several persons to whom I wish to express my appreciation for their services. I am pleased to express my appreciation first of all to Dr. F. E. Clements, of the University of Minnesota, who visited my field briefly in I9I4, for many valuable criticisms and suggestions. Dr. Raymond J. Pool, of the University of Nebraska, has read the first draft of this paper and I am grateful to him for kindly suggestions. Thanks are due to Dr. T. C. Frye, of the University of Washington, for the identification of a number of mosses, and to the late Dr. H. E. Hasse of Santa Monica, California, who was kind enough to identify all of my lichens. Wilting coefficient determinations of soils were made under the direction of Dr. L. J. Briggs, of the United States Department of Agriculture, to whom I wish to express my appreciation. The chemical and physical analyses of soils were made by the departments of chemistry and soils respectively, of the Washington Agricultural Experiment Station at Pullman. I wish further to acknowledge my indebtedness to Mr. Walter L. Muenscher and 
Mr. Earle Gibb, my one-time students, the former having assisted me in the field during the entire summer of I9I3, and the latter during I9I4. Finally, I wish to express my appreciation to Dr. Harry B. Humphrey, now of the Bureau of Plant Industry, and formerly my colleague in the Washington State College, for his kindly interest in the work during the first year of the investigation.

\section{EXTENT AND POSITION OF THE AREA}

The area under consideration includes approximately 4,000 square miles of territory located in southeastern Washington and adjacent Idaho. On the south it extends toward the foothills of the Blue Mountains, and reaches northward to the vicinity of Spokane. Its western limit is about 50 miles from the Idaho boundary, while in Idaho it includes a strip about ${ }_{5} 5$ miles in breadth. This area lies in the eastern part of the great Columbia Plateau and extends eastward into the foothills of the Bitterroot Mountains. The 47 th parallel of latitude passes through the center of this region, while it is bounded approximately on the east and west by longitude $I I 7^{\circ}$ and $I I 8^{\circ}$ respectively. Altitudinally, it ascends from about $\mathrm{I}, \mathrm{I} 75$ feet on its western border to a height of 4,000 feet in the mountains. The lowest point, about 520 feet, is reached in the Snake River Valley, while Cedar Mountain, near the Washington-Idaho line, reaches a height of 4,950 feet. While the above boundaries limit in a general way the investigations recorded in this paper, without doubt the vegetation in adjoining regions is not far different from that here described.

The peculiar topography, together with the range in altitude, gives this area three clearly defined plant formations, ranging from the desert-scrub formation, through the prairie formation to the Pacific Coast forest formation. A brief statement of the geology and topography of the region will help to make clear the reasons for the present distribution of plant communities.

\section{PHYSIOGRAPHIC REGIONS AND GEOLOGY}

The part of the state of Washington lying east of the Cascade Mountains is divided naturally into three great physiographic 
provinces. The Okanogan Highlands occupy the northeastern part of the state, while the Blue Mountains cover a relatively small area in the southeastern part. The remainder and larger part of the area makes up the Columbia Plateau.

The Okanogan Highlands consist mainly of gently rounded hills rising into peaks 4,900 to 6,600 feet high. Geologically, they are similar to the northern part of the Cascades and are composed largely of granite. They form, with the adjacent mountains of British Columbia, a connecting link between the Cascades and the Rocky Mountain system in Idaho. They are important in connection with these studies mainly for the ameliorating effect they exert upon the climate, and for the rôle they have played in plant distribution in the foothills of the Bitterroot Mountains.

The portion of the Blue Mountains occurring in Washington are composed wholly of basalt, and represent a great uplift of this rock surrounding a central mass of granite peaks. In Washington they reach an elevation of more than 6,500 fest, while in Oregon they rise about 3,300 feet higher.

The Columbia Plateau is thus bounded in Washington on three sides by high mountain ranges, while in Idaho, on the east, it merges into the Bitterroot Mountains. The plateau forms the greater portion of eastern Washington, and is made up of an immense mass of basalt, known geologically as the Columbia River basalt. This basalt is the result of a series of lava overflows which involved not only Washington, but also large areas in Oregon and Idaho, and even northern California. In Washington it covered all of the region south of the Okanogan Highlands and extended westward from the Bitterroot Mountains to the Cascades. These basaltic lavas were extruded in a highly fluid condition from numerous vents thickly strewn over the floor of the region, and were spread over the surface in great flows ( $I$, $12,13,14)$. The apparently flat basaltic plains stand out in sharp contrast to the mountain borders. The floor upon which the lava was extruded had considerable relief and was not greatly unlike the present Okanogan Highlands, with canyons, gorges, and mountain peaks; the whole showing a state of vigorous dissection (14). The effect of the basaltic inundations was to fill 
the valleys, and, to a large extent, bury the old topography. An average thickness of at least 4,200 feet has been estimated for the Columbia basalt in Washington. For the most part, the Columbia River lava completely covered all of the older rocks over which it flowed. Exceptions to this appear in peaks which were too high to be overwhelmed, such as Kamiak Mountain and Steptoe Butte in eastern Washington. Likewise, old divides extend into the basaltic fields as capes or promontories against which the lava came to rest. These older rocks, like those of the foothills of the Bitterroot Mountains, are mainly granites, gneisses, schists, and quartzites. Canyon walls, notably those of Snake River, not only reveal the older rock, but also expose the successive lava flows with their beds of dust and lake deposits. Snake River has cut down to a distance of over I, 600 feet and has uncovered in places the tops of buried mountains. Its canyon shows at least ten overflows of the lava. Between some of these overflows sufficient time elapsed for soil to form and forests to grow. The evidences of the latter appear either as charcoal or as silicified tree trunks. Geological investigations indicate that the great outpourings of lava were antecedent to the main uplift of the Cascade Mountains. The appearance of these mountains so effectually modified the climate by cutting off the cool, moist, southwest winds as to make much of the region eastward quite too arid for forest growth.

\section{SOILS}

The basalt, although hard and resistant to forces which abrade it, yields with comparative rapidity to agencies which tend to disintegration and decay. The weathered basalt has decomposed to form a rich residual soil which mantles the surface and gives its slopes characteristically soft, rounded, flowing outlines. It consists of a friable, dark-brown silt loam, with a depth ranging from a few inches to several feet. The subsoil consists of a lightbrown silt loam. It is heavier and more compact and plastic than the surface soil. Both soil and subsoil are extremely retentive of moisture. They form a mantle usually many feet deep, and only along the canyons of streams, or in the scab-rock 
in the western part of the area, is the basalt exposed. Westward the soil becomes lighter in color, and in some cases is impregnated with alkali.

Calkins (I) has advanced the theory that the soils in many parts of eastern Washington have been formed by wind action and are not of a residual nature. His conclusion is based upon the facts that in many parts of southeastern Washington there is an absence of lamination in the soil, that it is extremely fine in - texture, that there is a remarkably sharp definition between the soil and basalt, and that comparative chemical analyses indicate soils not of the character naturally to be expected from the decomposition of basalt in this climatic province. He believes the principal source of the material was from the soft sedimentary beds in the southwestern portion of the Columbia Plateau. However, the fact that there are no enclosed and undrained basins, as there must be had wind been the only agent at work, leads one to conclude that water erosion has also been an important factor in forming the present topography.

By the action of water, and especially the prevailing southwest wind, the plateau has been moulded into rounded hills not unlike sand dunes. The soils are constantly shifting from south and southwest to north and northeast slopes. This gives better weathering conditions on the exposed hillsides, while the soils are deepest on the brows of the slopes where there is the most favorable opportunity for the accumulation of wind-blown material.

As is characteristic of dry regions, the transition from soil to subsoil is not well marked, although the lighter-colored subsoil appears nearer the surface on exposed than on sheltered slopes. The proportion of clay is greatest towards the tops of the hills. Humus increases as one goes down the slopes and is highest in the valleys, where it forms a rich, black loam.

In contrast to the silt loam, grit-free soils covering the basalt, are the sandy loam soils formed from the disintegration of quartzite, granite, gneisses, and schists of the buttes and mountains. These vary so widely in mechanical composition, water holding capacity, 
and wilting coefficient, that they are considered in connection with the plant communities which they support.

\section{TOPOGRAPHY AND DRAINAGE}

Viewed from the top of a bordering mountain, or, better, from the summit of an isolated butte, the surrounding plateau looks

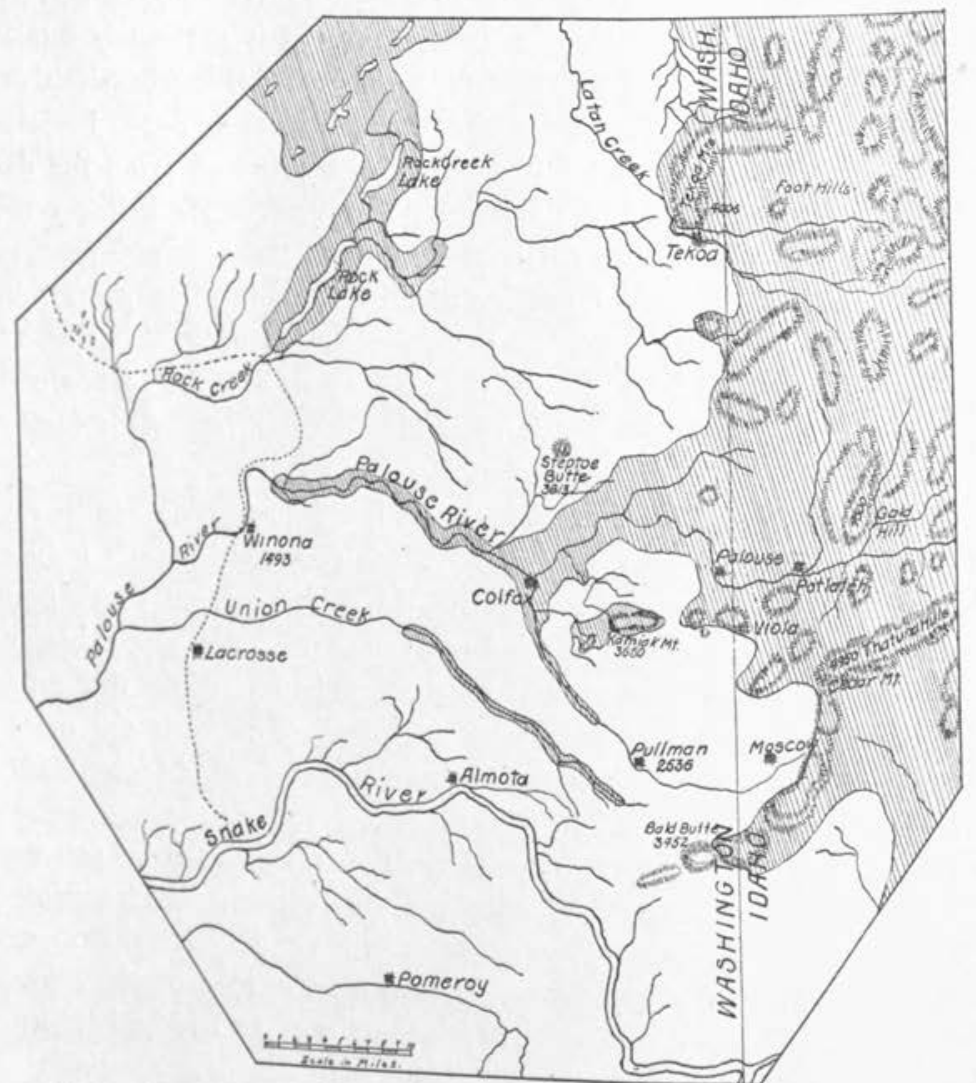

Fig. I. Map of southeastern Washington and adjacent Idaho. The shaded areas indicate coniferous woodland. Most of the outlying timbered areas are characterized by yellow pine. West of the dotted line and in the canyon of Snake River much of the area is characterized by scab-land covered with sagebrush or bunch-grass. 
not unlike the billowy surface of the ocean. The fine silt loam soil, from the disintegrated basalt, has been moulded by the action of wind and water into a dune-like topography (Fig. 38). Because of the constant shifting of the soils from the exposed south and southwest to the leeward slopes, the latter are much steeper. These hills reach a height of 100 to 360 feet. Measurements of a large number of slopes near the base station gave an average gradient of $12^{\circ}$ on the exposed sides, while the sheltered sides were from $5^{\circ}$ to $8^{\circ}$ steeper. Indeed, in parts of the region, many of the hillsides are so steep that they can not be brought under cultivation. The intervening valleys are usually narrow, but never form undrained basins. The general slope of the region is westward. While Thatuna Hills, a low, outlying spur of the Bitterroot Mountains, culminate in Cedar Mountain, 4,95o feet high, the eastern edge of the lava sheet reaches an altitude of only 2,750 feet (Fig. I). It descends at the rate of about 30 feet per mile, to $I, 170$ feet on the western border of the region under consideration.

Two main rivers with their tributaries drain the region except the northeastern part which is drained by tributaries of Spokane River. The Palouse River has its headwater tributaries in the mountains of Idaho, and after passing into Washington the north and south forks unite at Colfax. In the western part of the region it turns southwestward and finally enters the Snake River. At Colfax the river has cut a canyon into the basalt to a depth of 300 feet.

In general, the river canyons, whether large or small, are characterized by much steeper south and southwest than north and northeast banks. This is due in part to greater exposure of the north and northeast sides to temperature changes, and to wind action which erodes and carries away the soil materials, and in part to the constant covering of the sheltered sides by windblown material. These processes have a striking effect upon the vegetational cover. Locally the exposed canyon walls are known as rim-rock.

Snake River is joined by the Clearwater as it enters Washington. Tributaries of the latter drain the extreme eastern part of 
the region. Snake River flows westward through the region in a canyon which is simply an immense gorge a mile and a half to two miles wide hewn in the basalt. Although the canyon is over 1,600 feet deep, the river has not yet, except in a very few places, cut to the bottom of the basalt, for its present bed is still like its bluffs. The soil of these bluffs, as is characteristic of similarly exposed situations in the region, presents various stages of decomposition from the coarse talus at the foot of the cliff to well formed soil. The canyon at its bottom is scarcely wider than the river, except at the bends, where bars of moderate area have been formed. The soil of the bars is partially river-sand of granitic origin and partially wash from the bluffs.

Except for the Clearwater, no large streams enter Snake River in this region. Numerous small laterals have worked their way back into the basalt, and it is along these that the main canyon may be entered, especially from the south.

In general, the topography is young. The streams have not advanced far in their task of cutting away the rocks from the plateau and of reducing the land to base level. Especially south of Snake River, in Garfield County, where the surface is less rolling, one is impressed with the view of a land with a broad plateau surface and an infantile drainage. Here the spaces between the streams are flat-topped.

In the northwestern part of the area occur numerous small lakes, of which Rock Lake, about 0.5 mile wide and 7 miles long, is the largest. It is really a great crack in the basalt, with rocky canyon walls and basalt bottom. It connects northward with Little Rock Lake and is drained into the Palouse River by Rock Creek.

About these lakes, as well as along the canyons of the streams, the weathering of the edge of the basaltic sheets has caused them to recede unequally and to form steps or terraces in the faces of the precipices. Where the walls are steepest, they present a series of narrow steps covered with talus and soils in all stages of formation, separating vertical masses of bare and frequently columnar rock 30 or more feet in height (Fig. 45).

In the drier western part of the region, where the disintegra- 
tion of the basalt is correspondingly of a smaller degree, the rock often crops out upon the surface. Such rocky lands are known locally as scab-lands. They often occupy what appear to be former river valleys, although they are now dry or contain only small streams or small groups of lakes. These valleys may be of considerable extent; the local names, "Eight-mile Flat," "Twelvemile Flat," etc., indicate their size.

Owing to the porous nature of the basalt, as well as to sheets of clay, sand, and gravel interspersed between the successive layers, springs are numerous throughout the region. Oftentimes, wells dug merely into the soil aftord a good supply of water, although they are usually drilled into the basalt (8). In other cases, as at Pullman, an abundant supply of fine artesian water is obtained from beds of sand and gravel between the layers of basalt.

Standing above the surrounding plateau are numerous isolated buttes and several ranges of low mountains. These are the tops of lofty mountains not overwhelmed by the flood of basalt. Among the former, Steptoe Butte, a perfectly conical peak with an altitude of $3,6 \mathrm{r}_{3}$ feet, is a landmark to be seen for miles. Likewise, Kamiak Mountain, running from east to west for a distance of over two miles, and reaching an altitude somewhat greater than Steptoe Butte, is equally prominent. In some cases, only a few acres of the tops of buried mountains show themselves above the basalt. Such a butte may be seen just west of Bald Butte, the culmination of a ridge of quartzite running out southwestward from Thatuna Hills. Tekoa Mountains, near Tekoa, Washington, are a low, outlying ridge of the Bitterroot system. They reach a height of 4,000 feet. Gold Hill, not far from Potlatch, Idaho, is the highest point (about 4,500 feet) of another group, while Cedar Mountain (4,950 feet), northwest of the Clearwater River in Idaho, is the highest point of a considerable range known as Thatuna Hills. These buttes and mountains are very old geologically as compared with the basalt, and are well eroded and mostly forest-covered. Southeastward their streams empty into the Clearwater River. Elsewhere they are 
drained by the Palouse River and in the extreme northeast by tributaries of Spokane River (Fig. I).

\section{GENERAL PLANT-LIFE CONDITIONS}

Hemmed in on all sides by mountains the region under consideration has a climate much warmer and much drier than one would expect at this altitude and latitude. The Okanogan Highlands on the north shelter it from cold winter winds, while on the east and south it is protected by the Bitterroot Mountain system and the Blue Mountains, respectively. The Cascades on the west intercept the rain-bearing westerly winds from the Pacific Ocean. Even where the prevailing southwest wind cutting through the mountain gap of the Columbia River and rising over the high plateau drops much of its moisture near the high eastern border, the annual precipitation is only 21.6 inches. Westward it decreases steadily with decreased elevation, giving an annual precipitation of only IO-I 3 inches near thề western boundary of the region.

In this semi-arid region where evaporation rates are very high, a knowledge of the distribution of rainfall and humidity is very important, for it is well known that scanty rainfall throughout the year, or relative dryness of the air and soil during the growing season, favors a sparse vegetation and the development of xerophytic forms. Since vegetation is not only an expression of present conditions, but to a greater extent a record of conditions that have obtained during a period of years, and since the record is not likely to be altered by a year or two in which conditions may depart from the normal, a study of the precipitation in Fig. 2 is instructive. This gives the mean monthly precipitation at Pullman, covering a period of twenty-four years, and is very representative of conditions in the high prairies. It may be seen at a glance that over two thirds of the precipitation occurs during the non-growing season, and that the light showers of July and August seldom have much influence upon the water content of the soil.

In order that the reader may realize the striking difference be- 
tween the distribution of rainfall of this region and that of the Great Plains east of the Rocky Mountains, Fig. 2 also includes the average monthly rainfall at North Platte, Nebraska. It also gives the precipitation at La Crosse, a station in the western part of the region.

However, it is not the absolute rainfall figures alone which furnish a criterion of climate, for the maximum duration of the

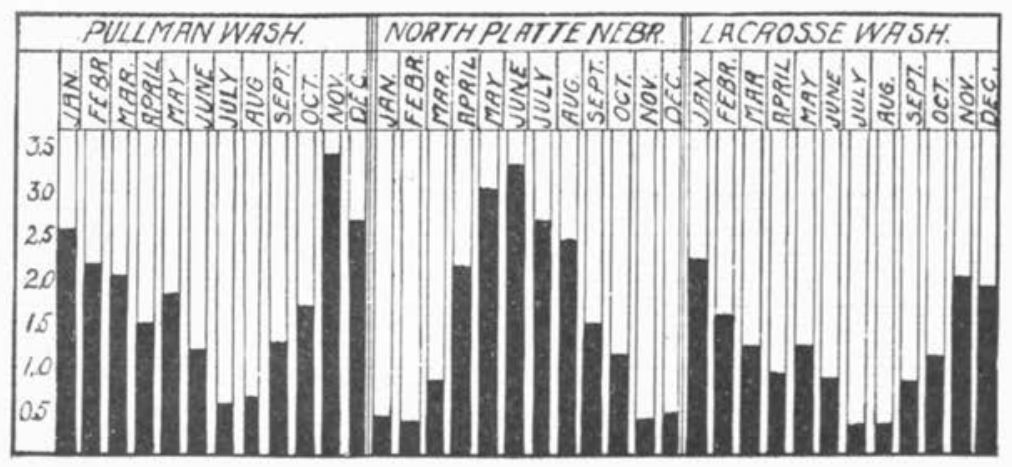

FIG. 2. Mean monthly precipitation in inches at Pullman and La Crosse, Washington, and North Platte, Nebraska.

drought period constitutes a limiting factor of the greatest importance.

During the dry summer months the sky is usually cloudless. At the base station the number of clear days during the growing season (April-October) was 68 per cent. for the years 1914 and 1915. Bright, warm days are followed by cool nights. In fact, a notable feature of the temperature of the region is the great variation between day and night temperatures, especially in summer, when a variation of $20^{\circ}$ to $40^{\circ} \mathrm{F}$. is not unusual. These cool nights naturally indicate rather late frosts in spring, and early ones in autumn. On the plateau, killing frosts not infrequently occur as late as the middle of May, and, of course, much later in the mountains. In the fall they may occur as early as the middle of September, although light frosts sometimes occur in August. The winters are mild and the prairie soils seldom 
freeze deeper than $4^{-6}$ inches. The snowfall normally is about 46 inches. The mean monthly and annual temperatures at the base station are given in Table I. It is interesting to note that the mean annual isotherms are approximately the same as those of eastern Nebraska. These are $52^{\circ} \mathrm{F}$. to $47^{\circ} \mathrm{F}$. These figures do not include the canyon of the Snake River, which has a distinctly warmer and drier climate.

TABLE I

Temperatures at Pullman, Washington

\begin{tabular}{|c|c|c|c|c|c|c|c|c|c|c|c|c|c|}
\hline & g् & : & $\dot{\frac{\pi}{2}}$ & 离 & 瓶 & $\stackrel{\varrho}{\Xi}$ & 离 & $\ddot{\theta}$ & 苛 & ठั & $\begin{array}{l}3 \\
z \\
z\end{array}$ & $\dot{\ddot{g}}$. & 运要 \\
\hline & $\begin{array}{l}35 \\
22 \\
\end{array}$ & $\begin{array}{l}36 \\
24 \\
\end{array}$ & $\begin{array}{l}47 \\
3 \mathrm{I} \\
\end{array}$ & $\begin{array}{l}56 \\
37 \\
\end{array}$ & $\begin{array}{l}63 \\
43 \\
\end{array}$ & $\begin{array}{l}72 \\
50 \\
\end{array}$ & $\begin{array}{l}83 \\
55 \\
\end{array}$ & $\begin{array}{l}83 \\
54 \\
\end{array}$ & $\begin{array}{l}70 \\
46 \\
\end{array}$ & $\begin{array}{l}56 \\
38 \\
\end{array}$ & $\begin{array}{l}42 \\
3 \mathrm{I} \\
\end{array}$ & $\begin{array}{l}35 \\
24 \\
\end{array}$ & \\
\hline Mean. & 29 & 32 & 38 & 47 & 53 & 59 & 67 & $\frac{77}{66}$ & 58 & 49 & 38 & 32 & \\
\hline
\end{tabular}

Since it is not the mean temperature of a region but rather the extremes that exert the most profound effect upon plants, Table $\mathrm{I}$ also includes the mean daily minimum and mean daily maximum temperatures.

Another important climatic factor is the wind. It is prevailingly from the southwest. Just as it has had such a profound effect upon moulding the topography of the region, likewise it has a marked effect upon the vegetation. Sweeping across the many miles of open prairie and desert of northern Oregon and south-central Washington, and not infrequently attaining a velocity of $30-50$ miles per hour, it has a marked effect upon the evaporating power of the air. By increasing the latter, it increases the saturation deficit and consequently accelerates transpiration. During the growing seasons of $1913-1914$, the wind blew from the southwest, or some southerly or westerly direction over 60 per cent. of the time. The southwest winds often assume the form of dust storms in summer. For days the air may be so filled with dust that the sun is scarcely visible. Such storms may become serious enough to cause much destruction.

Because of the deficient rainfall and the low humidity through- 
out the region, the vegetational distribution is markedly influenced by the edaphic and topographic conditions. The influence of rainfall upon the distributional and seasonal activities of plants is obviously exerted chiefly through its power to replenish soil moisture. While rainfall is only indirect in its relation to plants, soil moisture is direct. The retention of moisture by soil depends not only upon the kind of soil, but also upon the slope and exposure. These regional differences in precipitation, together with topography and soil depth, delimit in a more or less definite manner the plant communities.

It may make the situation somewhat clearer if, before taking up a detailed discussion of the structure and development of each vegetational unit, a brief survey of the chief plant groups in the succession is given.

\section{GENERAL VEGETATIONAL DISTRIBUTION}

The Festuca consociation of the Agropyron-Festuca association occupies the extreme eastern rim of the basaltic plateau, including the lower buttes and the exposed southwest slopes of some of the higher buttes and mountains (Figs. 2I and 22). This community extends from the yellow pine consocies of the Spokane gravels southward beyond Snake River. It occupies the part of the plateau having the deepest soils and the highest rainfall. Eastward it reaches to Tekoa Mountains, Thatuna Hills, and other outlying spurs of the Bitterroot system. The breadth of this belt is variable, depending upon the precipitation and soil moisture. Perhaps at no point does it exceed 40 miles. Westward and southward it merges into the Agropyron consociation (Figs. I9 and 20).

In the Festuca consociation, besides the blue bunch-grass (Festuca ovina ingrata) and Balsamorhiza sagittata, Agropyron spicatum (including variety inerme) is the most important component of the plant cover. In marked contrast to its bunch habit in the consociation bearing its name, in the more mesophytic Festuca community it is often a sod former. Other important grasses are Koeleria cristata and Poa sandbergii, while numerous composites, legumes, and other herbaceous species are abundant. Many of 
these do not occur in the Agropyron community, while indeed several species are confined to the moist north hillsides occupied by this consociation.

At lower altitudes westward and southward the well developed prairie gradually merges into the Agropyron consociation. Likewise, on the rim-rock along the canyons of streams as well as on dry mountain slopes this community is well represented. It is characterized by the definite bunch habit of its chief species Agropyron spicatum. These bunches are often more than 8 inches in diameter, and may reach a height of over 3 feet. In addition to the absence of numerous characteristically high-prairie species, and the more open nature of the plant cover, the Agropyron consociation is further characterized by the coming in of certain plants of a more xerophytic stamp. Most conspicuous among these are the rabbit brush, Chrysothamnus nauseosus (including var. graveolens), C. viscidiflorus, and several species of Eriogonum. The bunch-grass not only occupies the deeper soils of the drier region, but is represented in the scab-lands and on the rim-rock where the soils, only a few inches deep, overlie deeply fissured basalt.

On the unbroken rock, covered with only an inch or two of soil, Agropyron gives way to the Poa-Polygonum associes, a still earlier stage in development (Fig. I8). This latter associes is well represented on the rim-rock throughout the region, as well as over large areas of the scab-lands westward. The June grass, Poa sandbergii, Polygonum majus, and Plantago purshii, are the most important species. The knotgrass and plantain play the rôle of grasses ecologically. This associes is preceded in the succession by communities of mosses and lichens (Fig. I7).

In the driest part of the region, in the scab-land, where the basalt is almost free from soil, occurs the extreme eastward extension of the desert scrub formation. It is represented by the Artemisia-Atriplex association of which Artemisia rigida, the scab-land sage of the Artemisia consociation, is the characteristic species (Fig. I6). In the deeper soils impregnated with alkali the greasewood consocies, dominated by Sarcobatus vermiculatus, occurs. 
On the more mesophytic slopes of the treeless hills of the well developed prairie a poorly developed shrub associes occurs. This is made up of Symphoricarpos racemosus, Rosa nutkana, $R$. pisocarpa, dwarfed specimens of Prunus demissa, Crataegus brevispina, Amelanchier spp., and sometimes Opulaster pauciflorus, and small trees of Populus tremuloides. These shrubs are better developed in the canyons and are usually forerunners (especially Opulaster pauciflorus) of the yellow pine; along the stream margins they give way to the flood-plain forests of Populus, Crataegus, Amelanchier, Salix, and Alnus (Fig. 35).

On the outlying buttes as well as in the mountains, the Opulaster consocies often occupies considerable areas between the pines and the grass land (Fig. 23). It almost invariably occurs on the sheltered sides of lower buttes and mountain ridges, while its presence as a half-dead relict under the pioneer forest indicates its former possession of numerous other situations.

The Prunus consocies is less abundant than the preceding, but it is well represented in dry situations on butte and mountain sides. Like Opulaster, it is replaced by the pines in the normal succession. The chief species is the shrub-like tree, Prunus emarginata.

On the higher mountains especially, the Ceanothus consocies plays a rôle similar to the other shrubs of this associes. The two species $C$. velutinus and $C$. sanguineus, of which the former is the more important, act as forerunners for the yellow pine and Douglas fir.

The Pinus consocies is represented by the western yellow pine, Pinus ponderosa, the most xerophytic forest tree in the region. This consocies not only occupies dry slopes and ridges on the buttes and mountains, but has worked down along the Palouse River canyons as well as along Rock Lake and Rock Creek and Union Flat, to an altitude of only I,500 feet (Figs. I, 24, and 45). Everywhere the pine is the pioneer forest tree, and forms a fringing belt along the prairie. While it is usually preceded by some shrub consocies, yet it is able to invade the prairies, and especially those with a more sandy soil, without such an intervening stage.

The Pseudotsuga consocies, when pure, occupies dry, rocky 
slopes of the higher mountains, such as Gold Hill and Cedar Mountain. More usually Douglas fir is mixed with yellow pine, it being only slightly less xerophytic than the latter. Such mixtures of pine and Douglas fir frequently occupy large areas, the dominance of the latter indicating more mesophytic conditions (Fig. 25).

The Larix-Abies associes forms the chief forests of the region. The western larch, Larix occidentalis, being more xerophytic than the white fir, Abies grandis, is usually the first tree to appear in the Pseudotsuga consocies. Mixed forests of Douglas fir and larch are not infrequent. These often show relict pines and invading white firs. Such exposed situations as Kamiak Mountain and Tekoa Mountains are especially representative (Figs. 37 and 46).

Likewise, large areas of sheltered mountain slopes are characterized by Larix and Abies in nearly equal abundance, with a considerable admixture of Douglas fir on the drier slopes and the appearance of cedar, Thuja plicata, in the moist ravines (Figs. 26 and 27). Finally, in the deep ravines and most sheltered situations, the giant cedar, representing the climax community of the region, appears. Often it forms pure stands over local areas, the low light intensity excluding other trees (Fig. 28). But more frequently it forms a mictium with the white fir and larch, Abies being the last to drop out.

Each stage in forest succession is characterized by its particular group of shrubs and herbaceous vegetation. The story of succession from one stage to the next is largely a story of increasing water content and of decreasing light.

Perhaps this brief survey, together with a glance at the map (Fig. I), will enable the reader to grasp the general vegetational regions. Following is an outline of the units of vegetation and their subdivisions in the order of their development.

The developmental basis for the analysis of vegetation as set forth by Clements (2) is adopted here. Such a basis includes physiognomy, floristics, and habitat. For those who are not familiar with this basis of classification a few words of explanation may not be amiss. 
Pacific Coast Forest Formation

Thuja-T suga Association

Thuja Consociation (Fig. 28)

Larix-Abies Associes

Larix-Abies-Thuja Mictium (Fig. 27)

Pseudotsuga-Larix-Abies Mictium (Figs. 26 and 37 )

Pinus-Pseudotsuga Associes

Pseudotsuga Consocies (Fig. 25)

Pinus Consocies (Fig. 24)

Symphoricarpos-Opulaster Associes

Ceanothus Consocies

Opulaster Consocies (Fig. 23)

Prunus Consocies

Symphoricarpos-Rosa Mictium

Prairie-Plains Formation (Subclimax)

Agropyron-Festuca Association

Festuca Consociation (Figs. 21 and 22 )

Agropyron Consociation (Figs. 19 and 20)

Poa-Polygonum Associes (Fig. 18)

Polygonum Consocies

Plantago Consocies

Poa Consocies

Grimmia-Tortula Associes (Fig. 17)

Tortula Consocies

Grimmia Consocies

Gyrophora-Parmelia Associes (Fig. 17)

Parmelia Consocies

Gyrophora Consocies

Rhisocarpon-Lecidea Associes (Fig. 17)

Lecidea Consocies

Rhizocarpon Consocies

Desert Scrub Formation (Subclimax)

Artemisia-Atriplex Association

Artemisia Consociation (Fig. 16)

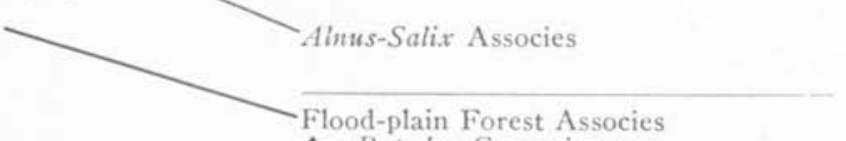

Flood-plain Forest Associes

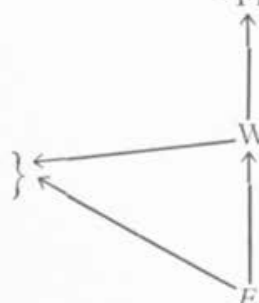

Salix-Crataegus Mictium (Fig. 35)

Wet Meadow Associes

Deschampsia Consocies

Wyethia Socies

Heracleum Socies (Fig. 34)

Iris Socies (Fig. 33)

Ouamasia Socies (Fig. 32)

Eleocharis-Carex Associes

Carex-Juncus Mictium

Eleocharis Consocies (Fig. 31)

Scirpus-Typha Associes

Typha Consocies

Scirpus Consocies (Fig. 3I)

Nymphaea-Potamogeton Associes Potamogeton Consocies (Fig. 20) Nymphaea Consocies (Fig. 30)

Chara-Potamogeton Associes

Potamogeton Consocies

Chara Consocies 
The formation is the unit of vegetation. It is the climax community of a natural area in which the essential climatic relations are similar or identical. It is an organic entity, covering a definite area marked by a climatic climax. It consists of associations which are actual parts of the area with distinct spatial relations.

The term association is restricted to those climax communities which are associated regionally to constitute the formation. Associations agree with their formations in physiognomy and development and are recognized chiefly by floristic differences.

The consociation is the unit of the association. It is characterized by a single dominant. While the association is actually a grouping, the consociation is pure dominance. In the usual treatment, most consociations appear as associations.

A society is a community characterized by one or more subdominants, that is by a species dominant over portions of an area already marked by the dominance of consociation or association. It is a localized or recurrent dominance within a dominance.

The above units of vegetation are essentially climax. The following are developmental, To ecologists who regard the formation as an actual organism, it is essential to distinguish developmental and climax communities.

The associes is the developmental equivalent of the association. It is composed of two or more consocies, $i$. e., developmental consociations, just as the association consists of two or more consociations. Like the association, it is based upon life-form, floristic composition, and habitat, but differs from it in as much as all of these are undergoing constant or recurrent developmental changes. While the association is permanent, in so far as development is concerned, the associes is transient although it may persist for many years.

A consocies is a developmental community marked by the striking or complete dominance of one species belonging to the lifeform typical of that stage of development. It differs from the consociation only in that it is a developmental or seral, while the latter is a climax community.

A socies is a seral society characteristic of a developmental 
community instead of a climax one. Like the society it is a case of subdominance within a dominance.

The following table shows the relation of climax and seral or development units to the formation, as well as the relation of the units of each series to each other and the correspondence of units in each series.

FORMATION

\begin{tabular}{ll}
\multicolumn{1}{c}{ Climax Units: } & \multicolumn{1}{c}{ Seral Units: } \\
Association & Associes \\
Consociation & Consocies \\
Society & Socies \\
EVAPORATION AND SOIL MOISTURE IN RELATION TO & SUCCESSION
\end{tabular}

Without question, the water relations of the habitat are the most important cause of succession. This is especially true of grass land communities, and even in forests where light is a controlling factor, it is well known that the water relation has a marked effect upon the tolerance of forest trees. As Fuller (4, 5) has pointed out, in a study of water conditions, two phases of the subject are of importance.

They are the direct source and amount of the supply and the region and cause of the loss. The latter is a climatic, the former largely an edaphic problem, for it is evident that plants derive their moisture from the soil and lose it into the air, and for the quantitative solution of these problems it is necessary to measure the power of the air to extract water from the plant; in other words, the evaporating power of the air, and the amount of moisture in the soil available for the use of plants.

Fuller $(4,5)$ and others have pointed out that the evaporation rates in the lower aërial stratum and the range of water content in the upper subterranean stratum are the most critical ones.

Within this (aërial) stratum develop all the seedlings, and upon their death or survival depends the character of the succeeding vegetation. Therefore, if the vegetation of an association so affects the evaporation rate of this stratum that it permits the survival of seedlings of more mesophytic species, it is evident that a more mesophytic association will develop, and succession will be accomplished.

Measurements of the water content of the soil and the evap- 
orating power of the air have been carried on in the various plant communities and a relation has been established between the moisture conditions and plant succession.

Livingston's standardized porous cup atmometers were used to determine the rate of the evaporating power of the air. They were always placed with the evaporating surfaces $17-23$ centimeters above the surface of the soil, care being taken in all cases to select spots which possessed the average amount of herbaceous, shrubby, or tree vegetation characteristic of the community as a whole. These cups were almost invariably run in duplicate, sometimes in triplicate; they were frequently checked and restandardized, and the readings reduced to those of the standard atmometer. In the following graphs, the ordinates give the average daily evaporation during the intervals indicated by the abscissas. A preliminary report giving a detailed statement of a part of these results has already been published (16).

Soil moisture determinations were made at the same stations and at the same time that evaporation readings were taken. In making the determinations, samples of IOO-I 50 grams were invariably taken in duplicate and from separate holes about 3 feet apart. These samples consisted of a core of soil to a depth of Io inches. They were dried in an oven at a temperature of 100$105^{\circ} \mathrm{C}$. and the water content calculated in percentages on the basis of the dry weight.

In the following figures, the results are represented graphically, the wilting coefficients being shown by lines of the same type as the line showing the range of soil moisture for a particular community. The ordinates represent the percentages of soil moisture and the abscissas indicate the intervals between readings. The intervals between the graphs and the lines denoting the wilting coefficients (if these exist above the latter) give the amount of available water.

During the summer of I9I3 a group of stations were established near Colfax, Washington. Here the south fork of the Palouse River has cut a canyon in the basalt to a depth of 300 feet. Along the north bank of this canyon the Agropyron consociation is well developed. The sheltered south bank is covered 
with a consocies of yellow pine, above which, and still on the north slope, the Festuca consociation continues. The atmometers in the Agropyron community were installed about half way up the bank of the canyon. Those in the pines were placed in a

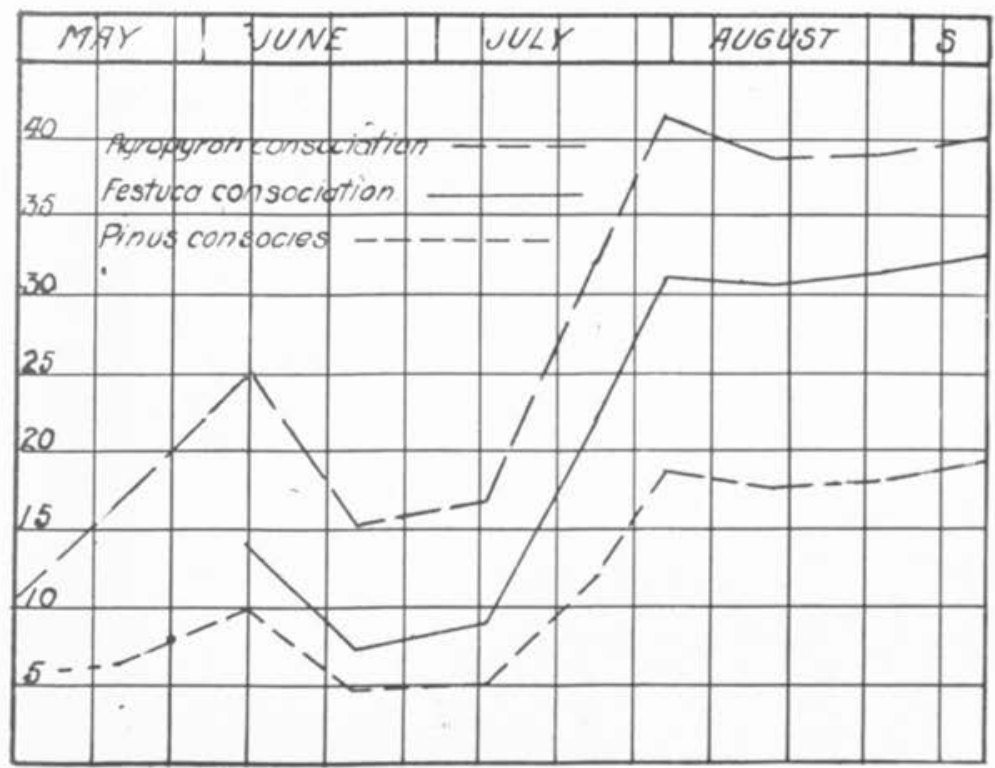

FIg. 3. Evaporation rates in the Agropyron, Festuca, and Pinus communities at Colfax, Washington.

similar position on the opposite bank, and about 60 feet beyond these a station was established in the Festuca consociation. Graphs of the data from these instruments have been plotted in Fig. 3.

These graphs show a striking decrease in the evaporating power of the air as the progressive stages of vegetational development are approached. During 1912 preliminary measurements indicated just such conditions in these communities. Stations maintained at Pullman during 1913 , showed similar differences in evaporation between the Agropyron and Festuca consociations, while during I9I4 further data at Colfax confirmed in general the above results. 
Fig. 4 shows the comparative average daily evaporation rates during 1913 in the three communities, respectively. These data

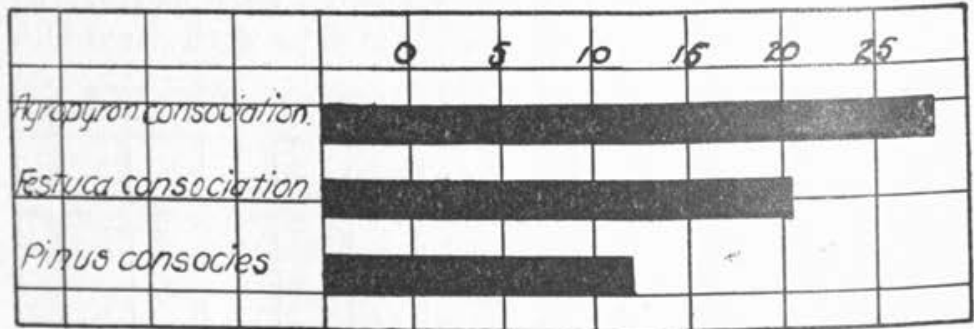

Fig. 4. Average daily evaporation rates in the Agropyron, Festuca, and Pinus communities during I9I3.

are averages of six stations located in the several communities.

The water content of the soils at the preceding stations at Colfax is indicated in Fig. 5. A glance shows that the soils covered by the Agropyron consociation had at all times the lowest available water content. Those of Pinus and Festuca communities are approximately the same, and indeed this condition has been found to exist elsewhere in several similar situations. Isolated determinations at the same stations at various intervals during the following season showed a similar water content relationship.

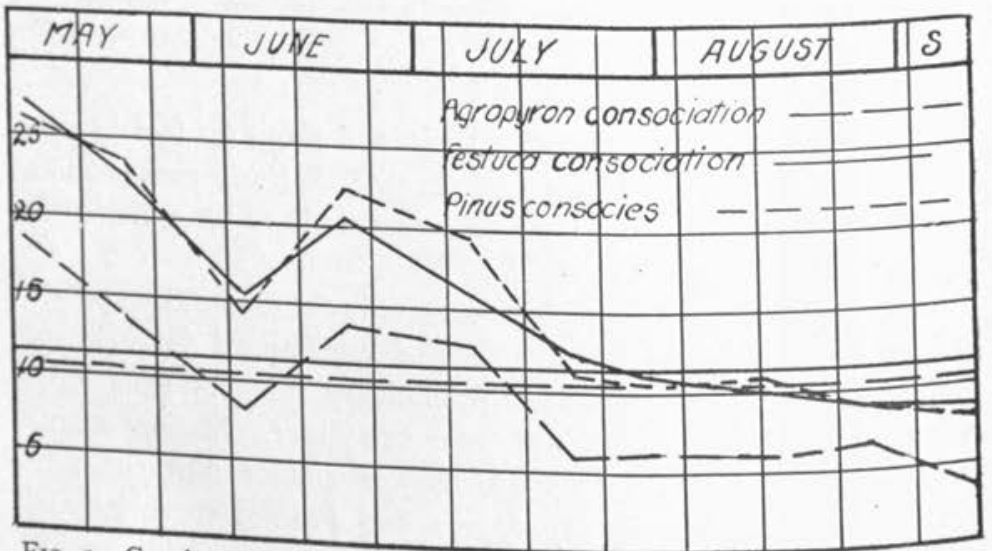

FiG. 5. Graphs showing the march of soil water to a depth of to inches in various plant communities at Colfax, Washington. 
But the soil water reached its non-available point somewhat earlier. However, the Agropyron consociation was the first to exhaust its available supply.

The enormous strain brought to bear upon these early developmental plant communities may be realized when it is noted that after the water of the first io inches of soil became unavailable, the evaporation throughout the remainder of the season was very high. Two methods of meeting these adverse conditions are employed by plants of these communities. They either mature early and become dormant upon the approach of drought, or develop very extensive root-systems. But these had best be discussed under structure and development of vegetation.

The mechanical analyses of these soils show that those of the Agropyron consociation are of a coarser texture than those of the Festuca consociation (Table II). Likewise the humus and volatile matter were found to be lower in the former.

\section{TABLE II}

Mechanical Analyses of Solls from Various Plant Communities in Southeastern Washington and Adjacent IDAHo

\begin{tabular}{|c|c|c|c|c|c|c|c|c|}
\hline Station & $\begin{array}{l}\text { Gravel } \\
\text { Above } \\
2, \infty \\
\text { Mm. }\end{array}$ & $\begin{array}{l}\text { Fine } \\
\text { Gravel } \\
2.00 \\
\text { to } 1.00 \\
\text { Mm. }\end{array}$ & $\begin{array}{l}\text { Coarse } \\
\text { Sand } \\
x . \infty 0 \\
\text { to } 0.50 \\
\mathrm{Mm} \text {. }\end{array}$ & $\begin{array}{c}\text { Me- } \\
\text { dium } \\
\text { Sand } \\
\text { o.50 } \\
\text { to } 0.25 \\
\text { Mm. }\end{array}$ & $\begin{array}{l}\text { Fine } \\
\text { Sand } \\
0.25 \\
\text { to 0.x } \\
\text { Mm. }\end{array}$ & $\begin{array}{c}\text { Very } \\
\text { Fine } \\
\text { Sand } \\
0.10 \\
\text { to } 0.05 \\
\text { Mm. }\end{array}$ & $\begin{array}{l}\text { Silt } \\
0.05 \\
\text { to } 0.005 \\
\mathrm{Mm}\end{array}$ & $\begin{array}{l}\text { Clay } \\
0.005 \\
\text { to } 0.000 \\
\text { Mm. }\end{array}$ \\
\hline $\begin{array}{l}\text { Agropyron consociation, Col- } \\
\quad \operatorname{fax} \ldots \ldots \ldots \ldots \ldots \ldots \ldots \ldots\end{array}$ & & & I. 40 & 1.00 & 1.80 & 34.48 & 54.20 & 7.04 \\
\hline Festuca consociation, Colfax & $\ldots$ & $\cdots$ & .80 & .40 & .40 & 23.30 & 66.00 & 9.00 \\
\hline $\begin{array}{c}\text { Festuca consociation, Ka- } \\
\text { miak Mt } \ldots \ldots \ldots \ldots \ldots \ldots\end{array}$ & .68 & .40 & I. 40 & .42 & 5.80 & 26.80 & 54.10 & 10.83 \\
\hline $\begin{array}{l}\text { Pseudotsuga-Larix commu- } \\
\text { nity, Kamiak Mt......... }\end{array}$ & .60 & 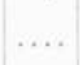 & .12 & .40 & I. 72 & 21.60 & $6 \mathrm{r} .80$ & $4 \cdot 34$ \\
\hline $\begin{array}{l}\text { Thuja consociation, Cedar } \\
\text { Mountain ................ }\end{array}$ & 6.08 & .62 & 3.60 & 1.60 & 3.60 & 21.65 & 57.60 & $5 \cdot 70$ \\
\hline 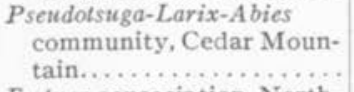 & 3.56 & 1.04 & 1. 52 & 1.08 & 7.82 & $25 \cdot 37$ & $55 \cdot 40$ & $4 \cdot 18$ \\
\hline $\begin{array}{l}\text { Festuca consociation, North- } \\
\text { east slope, Pullman...... }\end{array}$ & . & .40 & .40 & .90 & 1.50 & 33.16 & $53 \cdot 50$ & 10.03 \\
\hline $\begin{array}{l}\text { Festuca consociation, South- } \\
\text { west slope, Pullman...... }\end{array}$ & & & & .60 & .40 & $23 \cdot 5^{8}$ & $73 \cdot 30$ & 1. 49 \\
\hline
\end{tabular}


A chemical analysis not only confirms the low amount of volatile and organic matter, but also shows, as one would expect, the low nitrogen content of the new soil covered with bunch-grass (Table III).

\section{TABLE III}

Chemical Analyses of Solls from Various Plant Communities in Southeastern Washington and Adjacent Idaho

\begin{tabular}{|c|c|c|c|c|c|c|c|c|c|c|}
\hline & $\begin{array}{l}\text { Lime, } \\
\mathrm{CaO}\end{array}$ & $\begin{array}{l}\text { Pot- } \\
\text { ash. } \\
\mathrm{K}_{2} \mathrm{O}\end{array}$ & $\begin{array}{l}\text { Phos- } \\
\text { phoric } \\
\text { Anhy- } \\
\text { dride, } \\
\mathrm{P}_{2} \mathrm{O}_{5}\end{array}$ & $\begin{array}{l}\text { Soda } \\
\mathrm{Ash}_{2} \\
\mathrm{Na}_{2} \mathrm{O}\end{array}$ & $\left|\begin{array}{c}\text { So- } \\
\text { dium } \\
\text { Tri- } \\
\text { oxide, } \\
\mathrm{SO}_{3}\end{array}\right|$ & $\begin{array}{l}\text { Total } \\
\text { Solu- } \\
\text { ble } \\
\text { Salts }\end{array}$ & $\begin{array}{c}\text { Vola- } \\
\text { tileand } \\
\text { Or- } \\
\text { ganic } \\
\text { Matter }\end{array}$ & $\begin{array}{c}\text { Insolu- } \\
\text { ble } \\
\text { Matter }\end{array}$ & $\begin{array}{l}\mathrm{Hu} \text { (1- } \\
\text { mus }\end{array}$ & $\begin{array}{l}\text { Total } \\
\text { Nitro- } \\
\text { gen }\end{array}$ \\
\hline $\begin{array}{l}\text { Agropyron consocia- } \\
\text { tion, Colfax....... } \\
\text { Festuca consociation. }\end{array}$ & I. 08 & 0.58 & $0.3 \mathrm{I}$ & I.32 & 0.034 & 15.02 & $5 \cdot 35$ & 79.63 & 1.06 & 0.096 \\
\hline $\begin{array}{l}\text { Festuca consociation, } \\
\text { Colfax.............. } \\
\text { Festuca } \text { consociation, }\end{array}$ & 1.27 & 0.54 & 0.29 & 0.47 & 0.037 & 13.77 & 6.32 & 79.91 & 2.88 & 0.176 \\
\hline $\begin{array}{r}\text { Kamiak Mt. ..... } \\
\text { Pseudotsuga - La } i \text { ix }\end{array}$ & 1.03 & 0.45 & 0.29 & 0.06 & 0.047 & 13.50 & 5.95 & 80.55 & 2.77 & 0.182 \\
\hline $\begin{array}{r}\text { community, } \mathrm{Ka}- \\
\text { miak Mt........... } \\
\text { Thuja consociation, }\end{array}$ & 0.85 & 0.32 & $0.4 \mathrm{I}$ & $0.4 \mathrm{I}$ & 0.030 & 12.73 & 4.95 & 82.32 & I. 12 & $0.08 \mathrm{I}$ \\
\hline $\begin{array}{r}\text { Cedar Mountain.. } \\
\text { Pseudotsuga-Larix- } \\
\text { Abies community, } \\
\text { Cedar Mountain.. }\end{array}$ & 0.52 & 0.23 & 0.33 & 0.07 & 0.075 & 14.77 & 13.65 & 76.62 & 6.39 & 0.399 \\
\hline
\end{tabular}

A second set of stations was maintained on Kamiak Mountain, a bold butte lying 9 miles north of Pullman, and one of a series extending in a westerly direction from Thatuna Hills. This butte running from east to west for a distance of over 2 miles, and reaching an elevation of 1,000 feet above the surrounding hilltops, is covered on the south side with prairie, while the steeper north slope bears a dense forest of Douglas fir and western larch (Figs. 36 and 37 ).

On the south side trees occur only near the summit, where outcropping rocks furnish in their crevices a sufficient shelter and water supply for the establishment of the seedlings. Here is a very open growth of yellow pine which flanks the fir and tamarack and also occupies the less sheltered north base below the firtamarack community. In fact, this mountain offered so many interesting conditions of slope, exposure, and vegetational cover, that $\mathrm{I} 3$ stations were maintained here during I9I3. 
Eight miles east, near Viola, Idaho, on another butte slightly lower than Kamiak, but with plant communities very similarly distributed, records from a third set of stations were obtained. Here again the south side is prairie, which the pines, occupying the crest and northwestern slope, are gradually invading. The sheltered northeast side is clothed with a forest of Douglas fir and tamarack. These conditions are representative of numerous other situations (Fig. 46). Only as the mountains become higher and rainfall increases, does the prairie give way to a forest growth. The prairies at Kamiak and Viola are not greatly unlike those upon the basalt as far as kinds of species and their distribution are concerned, but, because of differences in soils and greater exposure to the wind, the vegetation bears a more xerophytic stamp and there are fewer plants per given area, and consequently more soil surface exposed.

Fig. 6 gives the evaporation rates in the various plant communities on Kamiak Mountain, and also that of the pine consocies at Viola, Idaho. A glance at the chart shows at once a direct relation between the evaporating power of the air and the stage in succession. The station on Kamiak in the Festuca consuciation was on a south slope and only about 60 feet below the edge of the pines. The station in the pines was in a decidedly xerophytic habitat, as is shown by the evaporation graph, which closely follows that of the prairie. The ground was covered with pine needles which almost excluded undergrowth and the atmometers were shaded only indifferently by the open growth of the trees. The evaporation data in a more typical yellow pine habitat located on the northwest slope of the butte at Viola is plotted on the same chart, for the sake of comparison. It corresponds in general with evaporation records secured from a second station in the yellow pines located at the north base of Kamiak Mountain, but from which complete data were not obtained.

Two stations were maintained in the shrub community. One of these was located on the south side of the mountain and on a northeast slope which was occupied by a very typical consocies of Opulaster pauciflorus, into which the pines were invading. The evaporation graph is given in the chart. It may be noted that 
this station was intermediate in xerophytism, as expressed by the evaporating power of the air, between the two stations in the pines. A second station in the shrub on the north slope of the butte and near the western end was maintained in a dense growth

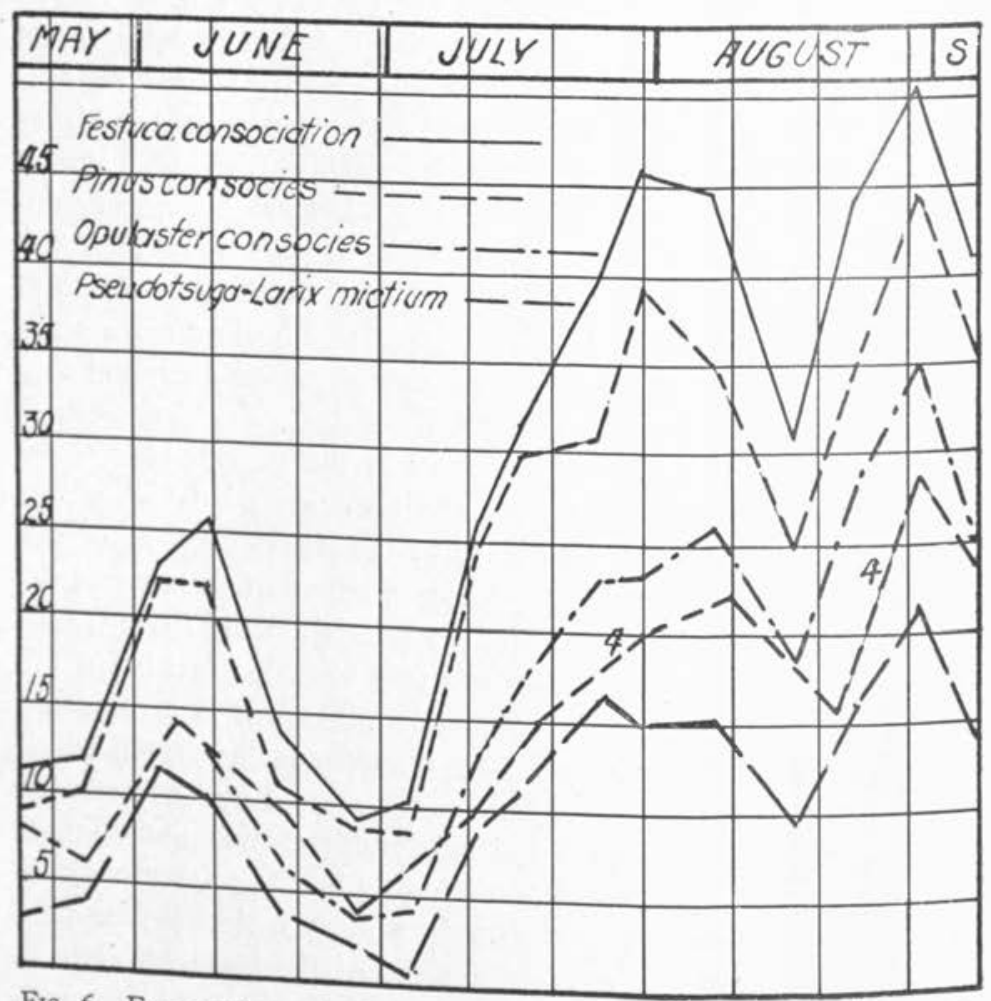

Fic. 6. Evaporation rates in the various plant communities on Kamiak Mountain, and in the Pine consocies (graph 4) at Viola, Idaho.

of Opulaster-Ceanothus chaparral. The evaporation rates, not shown in the chart, were much lower, often being less than those in the fir-tamarack forest. In fact, it is not difficult to find situations in which shrubby growth is so dense as to greatly retard evaporation and reduce the light to a point where pine seedlings 
The station in the firs and tamarack on the north slope of the mountain and only about 60 feet from the top, was in a forest of nearly pure second growth Pseudotsuga and Larix. These trees are mostly about thirty-five years old and are equally distributed, with a few relict pines and about three per cent. white fir. It may be noted that the graph of evaporation here is decidedly lower than in any other habitat.

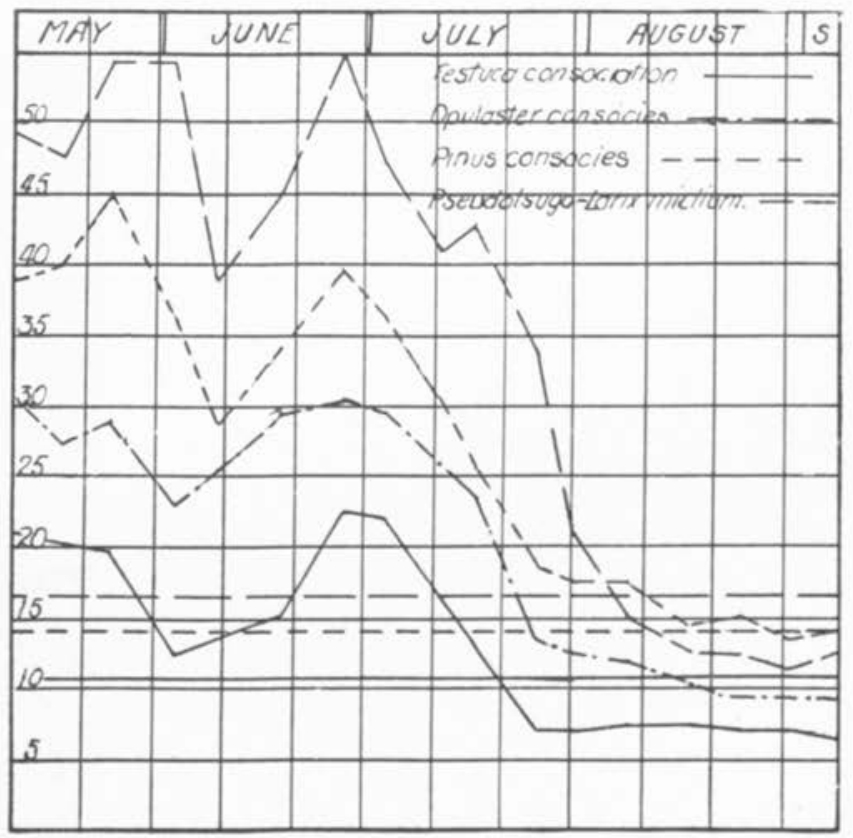

FIG. 7. Graphs showing the march of soil water to a depth of 10 inches in various plant communities on Kamiak Mountain.

The evaporation stations at Viola gave results comparable to those shown on the chart for Kamiak. Without exception, the average daily rate of evaporation in the prairie on the southwest slope was higher than that of the pines on the northwest slope. Likewise, the graph of evaporation in the fir-tamarack forest showed a continuously lower rate than that in the pines. 
At the stations on Kamiak Mountain where evaporation data were obtained, water content samples were taken at the same intervals of time. These data have been plotted in graphic form in Fig. 7. The water content of the soils of the pine consocies was obtained from the station at the north base of the mountain, that of the shrub from the Opulaster consocies on the northeast slope. The gradual depletion of the water content of these soils to the end of the growing season is characteristic. To fully appreciate the conditions represented on the chart, a description of the soils is necessary.

A mechanical analysis of the soils shows that those of the prairie are somewhat coarser textured than those of the firtamarack community (Table II). Likewise, a chemical analysis of these two types of soil shows that among other differences there is a markedly lower humus and total nitrogen content in the soils of the forest (Table III). This is due to fires burning out the organic matter.

The greatest difference in the soils, however, and the one which most profoundly affects the vegetation in this semi-arid region is their water holding capacity. An average of 6 tests showed the prairie soils on Kamiak had a water holding capacity of 48 per cent., while the finer soils of the north slope which support a forest of fir and tamarack hold 78 per cent. of their dry weight of water. The water holding capacity of the soil of the pine consocies was intermediate between the preceding. We may compare the soils of this region to a gigantic reservoir replenished mostly during the non-growing season and rather thoroughly emptied of its water during the summer.

The actual amount of water available to the forest- and shrubcovered soils of the protected slopes and ravines is often considerably greater than that of the prairie. Snow is blown from the wind-swept prairie and deposited on the sheltered slopes. I have seen such drifts 20-25 feet deep along the brow of Kamiak Mountain. The late melting of the snow makes a locally late spring and consequently shortens the period of drought in late summer.

Soil samples taken on Kamiak Mountain in May and in July, 1914, bear out the conditions found in the previous year, but 
here, as at Colfax, the available water was exhausted somewhat earlier than in the summer of I913. On July 14, 1914, and when the available moisture of the surface ten inches had been depleted in all habitats, samples were taken as usual at a depth of two feet in the prairie and fir-tamarack communities respectively. These showed that practically no water was available even at this depth.

The relation of soil moisture to plant succession was likewise determined at the stations already described near Viola, Idaho, during 1913. The results are plotted in Fig. 8. These graphs

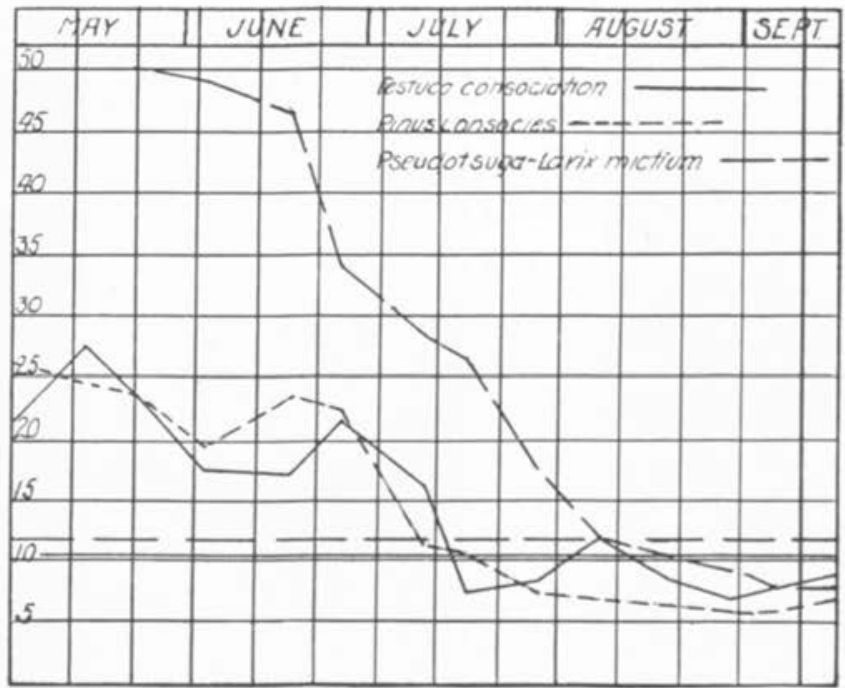

FIG. 8. Graphs showing the march of soil water to a depth of to inches in plant communities at Viola, Idaho.

appear somewhat different from those at Kamiak. This is due in part to the longer intervals between readings. Also the firtamarack station was somewhat less mesophytic than that at Kamiak, but like the former, was covered with a second growth of Douglas fir and tamarack. Likewise, the pine community was of a much more open type than that on the sheltered base of Kamiak Mountain. The water holding capacity of the soil at 
this station in the fir-tamarack community was 60 per cent., that of the prairie and pines about 45 per cent. On August I4, 1914, the water content at each station was found to be somewhat lower than on the same date of the preceding year. Samples taken to a depth of 3 feet in the prairie showed that all of the available water had been used. Indeed, at this time, practically all of the vegetation except Hoorebekia racemosa, Solidago missouriensis, Carum gairdneri, and a few other serotinal bloomers had dried up. An examination of the root-systems of numerous prairie species shows, however, that many of them obtain water at much greater depths than 3 feet (Figs. ${ }_{5} a, 1_{5} b$, and ${ }_{1} c$ ). In able underlying rocky soil on this butte it is probable that considerwas unable to still available at this date. Because of the rocks, I pine conable to secure samples at greater depths than 2 feet in the drier than thity, but these soils on August I3, I914, were even fir-tamarack those in the prairie. Likewise, the deeper soils in the Therack community were very dry.

prairie and pine cority in water content between the soils of the the latter consocies communities is just what one might expect when of organic matter had been adde open and only small amounts similarity matter had been added to the soil. There is a close communities In order to determine same stage of development.

power of the air and the relation between the evaporating community as coir and the water content of the soil in the cedar of stations was mained with earlier stages in succession, a series mers of I 1913 and 19 aintained on Cedar Mountain during the sumthe climax 19 and 19r4. A station was maintained in an area of through which flows which occupied a north slope and a ravine cent. Pure which flows a small stream. This forest is over 95 per feet in diame cedar, mostly large trees from 2 feet to more than 3 of which areter. The rest of the trees are large white firs, most Phytic shrubs and. The characteristic undergrowth of mesoAbout 700 feet beyond need no described here.

a slope somewhat beyond the station in the cedars and occupying comme somewhat above the latter, a station in the fir-tamarack Munity was maintained. The Douglas fir and tamarack are 
the principal trees, but a considerable amount of white fir and some spruce (Picea engelmanni) are also present. The undergrowth is rather sparse.

The evaporation in the cedar forest was always lower than that in the preceding developmental communities. The data taken in the cedars are shown in Fig. 9. Those of the other forest sta-

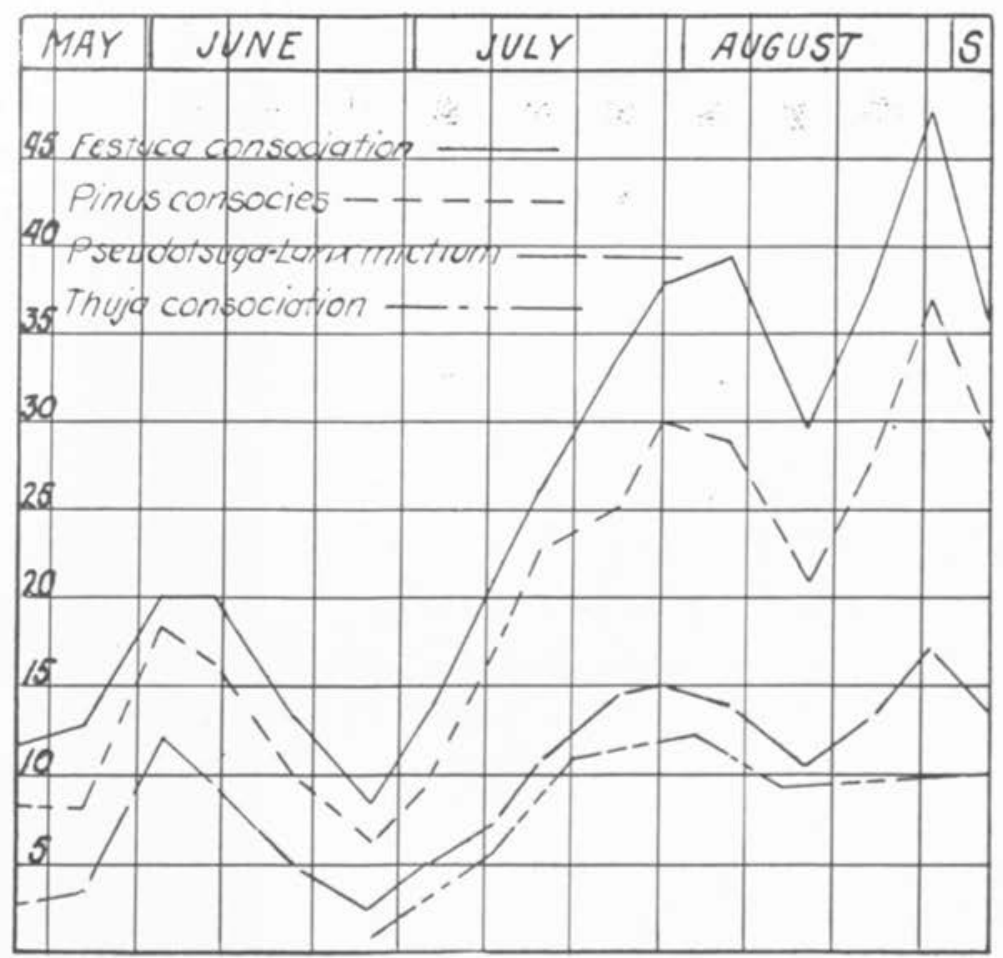

FIG. 9. Combined graphs showing the average daily evaporation rates at all the stations in the prairie, pine, and fir-tamarack communities on the buttes and mountains. The lowest graph gives the average daily evaporation in the Thuja consociation.

tions are shown combined with all other readings taken in the fir-tamarack forest. For the sake of comparison, the chart also gives combined graphs showing the average evaporation rates in 
the butte-prairie and yellow pine communities. These data show a marked relationship between the evaporating power of the air and the stage of succession. Fuller $(4,5)$ has determined a similar relationship for the plant consocies which culminate in the beech-maple climax forest. It is interesting to note in this connection that the evaporating power of the air in the Thuja climax forest is only slightly greater ( 0.5 c.c. daily in $19^{1} 3$ ) than that of the beech-maple forest climax of the East.

In order to further check these results, evaporation readings were taken again in the cedars and fir-tamarack on Cedar Mountain during I9I4. To this series of stations was added one in a very open yellow pine consocies on a wind-swept western slope. The results are given in Table IV.

TABLE IV

Showing the Average Daily Evaporation Rates in the Pine, FirTamarack, and Cedar Communities during the Summer of 1914

\begin{tabular}{|c|c|c|c|c|c|c|}
\hline 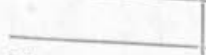 & July $3-1 x$ & July $x-18$ & July $18-25$ & 25-Aug. 1 & Aug. $x-7$ & Aug. $7^{-14}$ \\
\hline $\begin{array}{l}\text { Pines........... } \\
\text { Fir-tamarack... } \\
\text { Cedars......... }\end{array}$ & $\begin{array}{l}\text { I9 c.c. } \\
\text { I3 c.c. } \\
\text { Io c.c. }\end{array}$ & $\begin{array}{l}24 \\
13 \\
10 \\
\end{array}$ & $\begin{array}{l}37 \\
20 \\
\text { I } 4 \\
\end{array}$ & $\begin{array}{l}35 \\
20 \\
16\end{array}$ & $\begin{array}{l}40 \\
23 \\
18\end{array}$ & $\begin{array}{l}34 \\
22 \\
17\end{array}$ \\
\hline
\end{tabular}

A record of the water content of the soils at the stations in the cedars and fir-tamarack on Cedar Mountain was kept from June
14 to September period, and to this a record During I9I4 this was repeated for a the pine community was added. ically in Fig. I0. A glance shows the results are shown graphthe most mesophytic glance shows that the cedars occupy by far cates at once a fine textured soil with con wilting coefficient indiA mechanical soil analysis (Table considerable organic matter. teristics. This is in marked contrast) reveals just such characthe station in the pine. Likewist to the coarse sandy loam of shows 13 per cent. of volatile and organic analysis (Table III) cedar community, and 8 per cent. in those occupied by the firs and tamaracks. The water holding capacity of these soils is re-
markably high. It was found to be over Ioo per cent. of their 


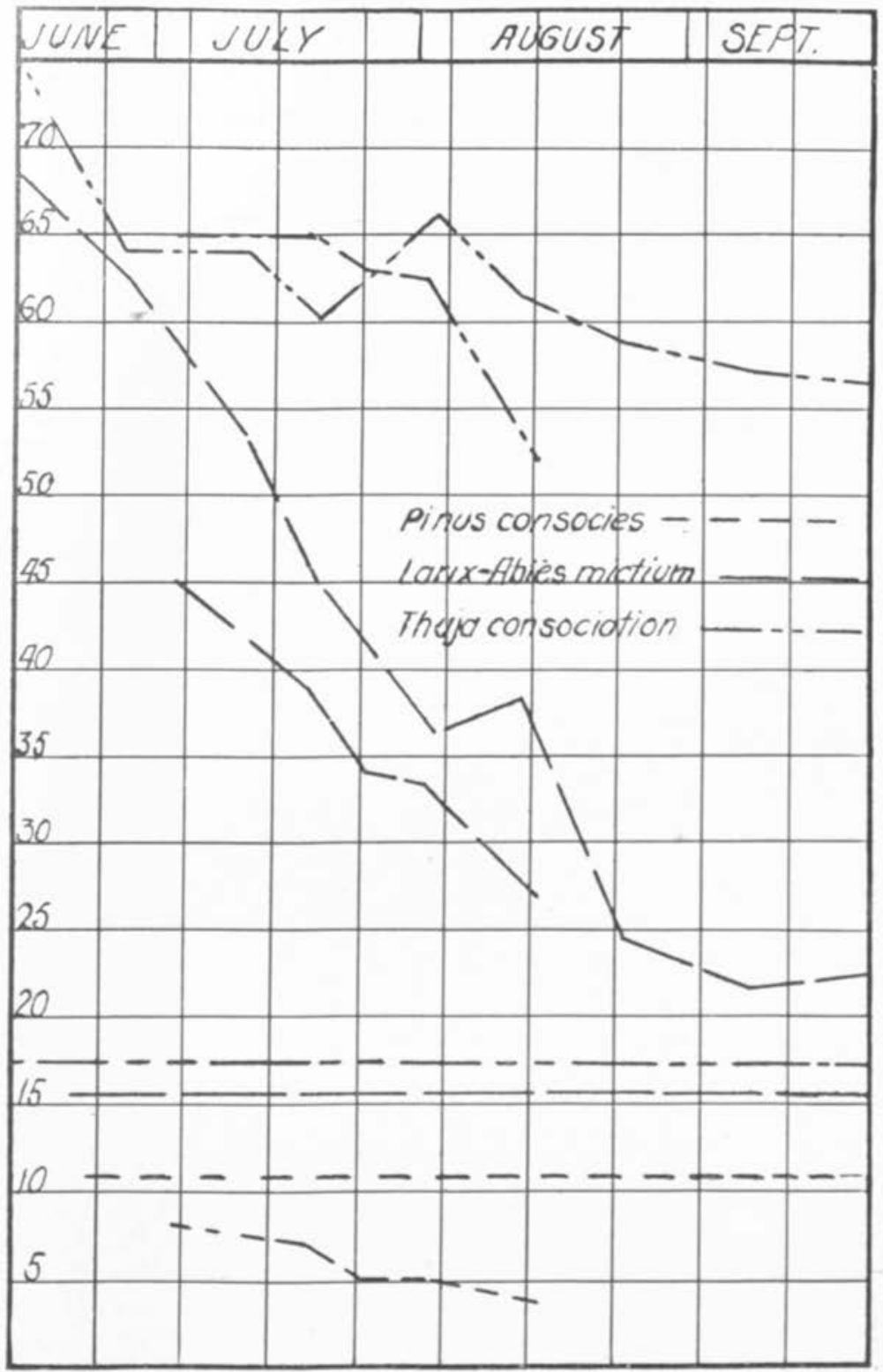

FIG, 10. Graphs showing the march of soil water in various plant communities on Cedar Mountain. 
dry weight. The chart shows that at no time did these virgin forests of fir-tamarack or cedar exhaust all of the water in the surface ten inches of soil. Likewise, samples at a depth of 2 feet on Auguist I, I9I4, gave a water content of 66 per cent. and I9 per cent. in the cedar and fir-tamarack forest respectively. Similar determinations at 2 feet in the rocky pine-covered soils gave a water content of about Io per cent., which is very near the wilting coefficient. The slow growth and dwarfed appearance of these trees reflect the unfavorable habitat conditions.

These studies on the evaporating power of the air and the amount and range of soil moisture in different plant communities may be briefly summarized.

Evaporation at different stations within the same plant community exhibits variations similar both in character and degree, and the variations in the rate of evaporation gradually become less and less as the climax type of vegetation is approached. The great amount of evaporation in the earlier stages of succes-
sion seems a sufficient cause for the xerophytic character of the vegetation.

A study of the differences of the rates of evaporation in the various plant communities shows that these differences are sufficient to be important factors in causing succession, at least through the earlier stages, where light does not play an importan
rôle. $^{1}$

If sufficient light is available, there is no question but that humidity of the air and the soil are the most important factors ${ }^{1}$ While reading proof of this manuscript the recent paper by Gates came
to the writer's notice. (Gates, F. C. The relation between evaporation
and succession in and succession in a given area. Am. Journ. Bot., 4: $161-178,1917$.) As a that of an investigation carried on at Douglas Lake, Mich., he concludes evaporatioase in evaporation is not a prerequisite to succession; lowered worked in being coincident with and not an antecedent to it. Gates of evaporatiogion with summer rainfall, where the average daily rates obtained on open not applicable to ground was only I $4.7 \mathrm{cc}$. Certainly his conclusions are areas covered to a region of practically no summer rainfall and where, in growing season averaged 28 to 37 cc., with the average daily rate for cer- 
affecting the establishment of the different plant communities. The progressive increase of the humidity of the habitat causes a corresponding increase in the mesophytism of the plant associations. This change of plant population from the xerophytic to the mesophytic type is a phenomenon called succession.

The evaporation rates and the amount of soil moisture in the various communities vary in general directly with the order of their occurrence in the succession, the climax community being the most mesophytic in both respects.

\section{SOIL TEMPERATURE IN RELATION TO SUCCESSION}

The temperature of the soil gives in a general way a summation of the heat factors of the habitat. It combines the effects of direct insolation and radiation, cooling by the retention of snow or by the evaporation of moisture, and variations in temperature caused by the passage of currents of air. Since plant communities react directly on temperature, a large number of soil temperature readings were made in the various plant communities to detain weeks in mid-summer, even in well developed prairie, reaching $64 \mathrm{cc}$. (Gates highest evaporation rate on open ground for a single week is 21.6 cc. per day.)

Students of succession should keep in mind that the evaporating power of the air affects the possibility of water intake as well as water outgo. High rates of evaporation rapidly deplete the surface soil of water as well as desiccate the plant. Mesophytes can not establish themselves under such conditions. It is only after a cover of xerophytes cuts down the great evaporating power of the air in the stratum in which seedlings develop, by shading and by inhibiting wind movement that mesophytic plants can establish themselves. Mesophytes do not replace xerophytes in succession until the reaction of the latter on the habitat is such as to make possible the requisite conditions of soil and air humidity, i. e., a condition where sufficient water is available in the soil and air, so that transpiration may not exceed absorption. That evaporation is further reduced by the mesophytes is repeatedly shown in the preceding data. Conditions for plant life are then less severe and even more mesophytic plants can establish themselves and become dominant.

This concept is in agreement with Fuller's conclusion, which he reached after several years of study in the Chicago region (5). Further evidence is brought forward in a recent paper dealing with the prairie-forest problem in Minnesota and Nebraska. (Weaver, J. E., and Thiel, A. F. The Bot. Surv. Nebr, N. S., 1: 1-60, 1917.) 
termine the relation between this factor and succession. Readings at depths of 2 and ro inches respectively, were taken at the same stations and at the same time that soil samples for moisture determinations were secured. In addition to these a large number of readings near the soil surface, in the soil surface, and at depths of one and two feet respectively, were made from time to time. Many of the temperature readings were made simultaneously, and in all cases recorded the interval between the readings at the various stations was so short that the error thus introduced is almost negligible. This possible error was further reduced by taking the readings in the various habitats at any set of stations in varying sequence.

An examination of these data shows almost uniformly a decrease in soil temperature as the climax communities are approached. The following tables, selected as representative from these data, are illustrative:

\section{TABLE V}

Showing the Relation of Soil Temperature to Plant Succession

Colfax, Wash., I9I3

\begin{tabular}{|c|c|c|c|c|c|c|c|}
\hline & $\begin{array}{l}\text { Agro- } \\
\text { Pyonon } \\
\text { Ponso- } \\
\text { ciation }\end{array}$ & \begin{tabular}{|c|} 
Festuca \\
Conso: \\
ciation
\end{tabular} & $\begin{array}{c}\text { Pinus } \\
\text { Conso- } \\
\text { cies }\end{array}$ & $\begin{array}{l}\text { Agro- } \\
\text { pyron } \\
\text { Conso- } \\
\text { ciation }\end{array}$ & $\begin{array}{l}\text { Festuca } \\
\text { Conso- } \\
\text { ciation }\end{array}$ & $\begin{array}{c}\text { Pinus } \\
\text { Conso- } \\
\text { cies }\end{array}$ & \\
\hline & \multicolumn{3}{|c|}{ Depth, 2 Inches } & \multicolumn{3}{|c|}{ Depth, xo Inches } & \\
\hline 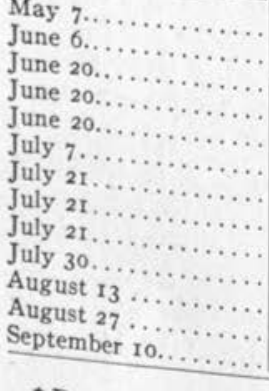 & \begin{tabular}{|l|}
31.0 \\
17.5 \\
22.5 \\
21.5 \\
29.0 \\
26.5 \\
28.0 \\
32.5 \\
35.0 \\
$20.5^{*}$ \\
26.5 \\
$22.5^{*}$ \\
\end{tabular} & \begin{tabular}{|l|}
$20 .{ }^{\circ} \mathrm{C}$. \\
21.5 \\
16.2 \\
17.5 \\
17.5 \\
19.5 \\
23.0 \\
22.5 \\
22.0 \\
22.0 \\
$18.5^{*}$ \\
20.0 \\
$13.0^{*}$
\end{tabular} & \begin{tabular}{|l|}
8.7 \\
12.5 \\
12.5 \\
12.5 \\
13.0 \\
15.0 \\
18.0 \\
17.5 \\
18.0 \\
14.0 \\
$15.0 *$ \\
15.0 \\
II. $5 *$
\end{tabular} & $\begin{array}{l}\text { I5.0 } \\
19.5 \\
15.5^{*} \\
20.0^{*} \\
19.0^{*} \\
27.0^{*} \\
25.5^{*} \\
27.0^{*} \\
29.5^{*} \\
28.0^{*} \\
22.0 \\
22.5 \\
19.5\end{array}$ & $\begin{array}{l}13.0 \\
15.0 \\
15.0^{*} \\
16.5^{*} \\
17.0^{*} \\
19.0^{*} \\
22.0^{*} \\
24.0^{*} \\
25.0^{*} \\
20.0^{*} \\
18.5 \\
18.0 \\
14.5\end{array}$ & \begin{tabular}{|c|}
6.0 \\
I2.0 \\
I $2.5^{*}$ \\
I2.5* \\
I2.5* \\
I $4.5^{*}$ \\
I6. \\
I $7.0^{*}$ \\
I $7.5^{*}$ \\
I4.2* \\
I4.5 \\
14.0 \\
I 2.5
\end{tabular} & $\begin{array}{l}9 \text { A. M. } \\
2 \text { P. M. } \\
6 \text { P. M. } \\
\text { 9:15 A. M. } \\
\text { I:30 P. M. } \\
6 \text { P. M. }\end{array}$ \\
\hline
\end{tabular}

* Readings taken at a depth of 4 inches. 
Kamiak Mt., 1912

\begin{tabular}{|c|c|c|c|c|c|c|}
\hline & $\begin{array}{c}\text { Festuca } \\
\text { Consocia- } \\
\text { tion }\end{array}$ & $\begin{array}{c}\text { Pinus } \\
\text { Consocies }\end{array}$ & $\begin{array}{l}\text { Pscudo- } \\
\text { tsuga- } \\
\text { Larix } \\
\text { Mictium }\end{array}$ & $\begin{array}{c}\text { Festuca } \\
\text { Consocia- } \\
\text { tion }\end{array}$ & $\begin{array}{c}\text { Pinus } \\
\text { Consocies }\end{array}$ & $\begin{array}{l}\text { Pseudo- } \\
\text { fruga- } \\
\text { Larix } \\
\text { Mictium }\end{array}$ \\
\hline & \multicolumn{3}{|c|}{ Surface } & \multicolumn{3}{|c|}{ Depth, 12 Inches } \\
\hline May $3 \ldots \ldots .$. & $\mathrm{II} .0^{\circ} \mathrm{C}$. & 7.5 & 6.0 & 8.0 & 7.0 & 5.0 \\
\hline Mayr $2 \ldots \ldots \ldots \ldots$ & 27.5 & 15.5 & 10.5 & I 5.5 & 13.0 & 8.5 \\
\hline May $25 \ldots \ldots \ldots \ldots$ & II. 5 & II. 0 & 9.5 & 13.0 & 10.5 & 7.5 \\
\hline June $\mathbf{x} \ldots \ldots \ldots \ldots$ & 21.5 & 17.5 & I 4.0 & $3 t .5$ & 13.0 & 9.0 \\
\hline
\end{tabular}

1913

\begin{tabular}{|c|c|c|c|c|c|c|}
\hline \multirow[b]{2}{*}{ May $17 \ldots \ldots \ldots \ldots$} & \multicolumn{3}{|c|}{ Depth, a Inches } & \multicolumn{3}{|c|}{ Depth, $x 2$ Inches } \\
\hline & $10.0^{\circ} \mathrm{C}$. & $7 \cdot 5$ & 5.2 & 9.5 & 7.0 & 5.0 \\
\hline May $24 \ldots \ldots \ldots$ & 16.5 & 12.2 & 9.5 & 15.5 & $9 \cdot 5$ & 7.5 \\
\hline June $2 \ldots \ldots \ldots \ldots$ & 18.5 & 14.5 & 10.2 & 18.0 & I 1.7 & 10.2 \\
\hline June $8 \ldots \ldots \ldots \ldots$ & $24 \cdot 5$ & 13.0 & II.0 & 18.0 & $11 \cdot 5$ & 10.5 \\
\hline June $17 \ldots \ldots \ldots \ldots$ & 23.2 & 12.5 & 8.5 & $15 \cdot 5$ & 10.7 & 8.5 \\
\hline June $26 \ldots \ldots \ldots \ldots$ & 14.2 & II. 5 & 9.5 & $12.5^{*}$ & $10.2^{*}$ & $9.5^{*}$ \\
\hline July $2 \ldots \ldots \ldots \ldots$ & 9.7 & 11.5 & 9.2 & $10.7^{*}$ & $\mathrm{II} \cdot 5^{*}$ & $8.7 *$ \\
\hline July $15 \ldots \ldots \ldots \ldots$ & 17.0 & 12.2 & 10.2 & $16.5^{*}$ & $11.7^{*}$ & I0. $5^{*}$ \\
\hline July $27 \ldots \ldots \ldots \ldots$ & 35.0 & 17.5 & 16.0 & $24 \cdot 5$ & 14.5 & 13.0 \\
\hline August $6 \ldots \ldots \ldots$. & 22.0 & $\ldots$ & 14.5 & 21.0 & $\ldots$ & I. 1.5 \\
\hline August $15 \ldots \ldots \ldots \ldots$ & 19.7 & 12.5 & I 0.5 & $17.5^{*}$ & $12.5^{*}$ & $10.5^{*}$ \\
\hline August $22 \ldots \ldots \ldots \ldots$ & $25 \cdot 5^{*}$ & $16.5^{*}$ & $14 \cdot 5^{*}$ & 22.5 & 14.0 & 12.5 \\
\hline August $29 \ldots \ldots \ldots \ldots$ & $27.0^{*}$ & $16.0^{*}$ & $15.2 *$ & 23.0 & 14.5 & 13.0 \\
\hline September $5 \ldots \ldots \ldots$ & $21.5^{*}$ & $13.2^{*}$ & $11.2^{*}$ & 18.0 & 13.2 & $\mathrm{II} .2$ \\
\hline
\end{tabular}

- Readings taken at a depth of 4 inches.

Viola, Idaho, 1913

\begin{tabular}{|c|c|c|c|c|c|c|}
\hline & $\begin{array}{l}\text { Festuca } \\
\text { Conso- } \\
\text { ciation }\end{array}$ & $\begin{array}{l}\text { Pinus } \\
\text { Conso- } \\
\text { cies }\end{array}$ & $\begin{array}{l}\text { Pscudo- } \\
\text { tsuga- } \\
\text { Larix } \\
\text { Mictium }\end{array}$ & $\begin{array}{l}\text { Festuca } \\
\text { Conso- } \\
\text { ciation }\end{array}$ & $\begin{array}{c}\text { Pinus } \\
\text { Conso- } \\
\text { cies }\end{array}$ & $\begin{array}{l}\text { Procudo- } \\
\text { traga- } \\
\text { Larix } \\
\text { Mictium }\end{array}$ \\
\hline & \multicolumn{3}{|c|}{ Depth, 2 inches } & \multicolumn{3}{|c|}{ Depth, 20 inches } \\
\hline May $3 \ldots \ldots \ldots \ldots$ & $9 \cdot 5^{\circ} \mathrm{C}$. & 5.0 & 1.5 & 6.5 & $4 \cdot 5$ & I. 5 \\
\hline May $24 \ldots \ldots \ldots \ldots$ & I 8.0 & 10.0 & 10.0 & 13.5 & 8.5 & 7.5 \\
\hline June $x 8 \ldots \ldots \ldots \ldots$ & 16.0 & 12.0 & II.o & 15.0 & 11.0 & 9.0 \\
\hline June $26 \ldots \ldots \ldots \ldots$ & 21.0 & 12.0 & 11.0 & $19.5^{*}$ & $11.0^{*}$ & II. $0^{*}$ \\
\hline July to ............ & 21.0 & 13.0 & 12.0 & $20.5^{*}$ & $12.5^{*}$ & $11.7^{*}$ \\
\hline July $17 \ldots \ldots \ldots \ldots$ & 23.5 & 11.5 & II.0 & $20.0^{*}$ & I $1.5^{*}$ & $10.5^{*}$ \\
\hline July $29 \ldots \ldots \ldots \ldots$ & 17.5 & 12.5 & 12.0 & 19.0 & II.5 & 10.5 \\
\hline August $8 \ldots \ldots \ldots$ & I 8.5 & 14.0 & 13.0 & 20.0 & 13.5 & 13.0 \\
\hline August $20 \ldots \ldots \ldots$ & 28.0 & 13.7 & 11.7 & 19.0 & 13.0 & 11.5 \\
\hline August $30 \ldots .$. & $25.0 *$ & $16.0^{*}$ & $14.0^{*}$ & 21.0 & 15.0 & 13.0 \\
\hline September $6 \ldots . .$. & 24.0 & 12.7 & 11.0 & 17.5 & 13.0 & II.O \\
\hline
\end{tabular}

- Readings taken at a depth of 4 inches. 
Cedar Mt., 1914

\begin{tabular}{|c|c|c|c|c|c|c|}
\hline & $\begin{array}{c}\text { Pinus } \\
\text { Conso- } \\
\text { cies }\end{array}$ & $\begin{array}{l}\text { Larix- } \\
\text { Abies } \\
\text { Mictium }\end{array}$ & $\begin{array}{l}\text { Thuja } \\
\text { Conso- } \\
\text { ciation }\end{array}$ & $\begin{array}{l}\text { Pinus } \\
\text { Conso- } \\
\text { cies }\end{array}$ & $\begin{array}{l}\text { Laria } \\
\text { Abies } \\
\text { Mictium }\end{array}$ & $\begin{array}{l}\text { Thuja } \\
\text { Conso- } \\
\text { ciation }\end{array}$ \\
\hline & \multicolumn{3}{|c|}{ Depth, 2 inches } & \multicolumn{3}{|c|}{ Depth, ro inches } \\
\hline $\begin{array}{l}\text { July } 3 \ldots \ldots \ldots \\
\text { July } 18 \ldots \ldots \\
\text { July } 25 \ldots \ldots \ldots \\
\text { August } 1 \ldots \ldots \ldots \ldots \\
\end{array}$ & $\begin{array}{l}21.0^{\circ} \mathrm{C} \\
18.5 \\
19.5 \\
18.0 \dagger \\
\end{array}$ & $\begin{array}{c}14.5 \\
13.0 \\
12.0 \\
7.5 \dagger\end{array}$ & $\begin{array}{l}\text { I3.0 } \\
\text { I } 2.0 \\
\text { I1.0 } \\
6.5 \dagger\end{array}$ & 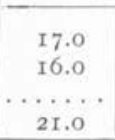 & $\begin{array}{l}10.0 \\
11.0 \\
10.5 \\
12.5\end{array}$ & $\begin{array}{r}10.0 \\
10.5 \\
9.5 \\
11.5 \\
\end{array}$ \\
\hline
\end{tabular}

$\dagger$ Readings taken at a depth of 2 feet.

A discussion of light values as affecting succession had best be given in connection with the study of the development of the forest communities.

\section{THE PRAIRIE-PLAINS FORMATION}

The prairies represent an extreme westward extension of the prairie-plains formation east of the Rocky Mountains. ${ }^{1}$ This great grass land area is here represented by the AgropyronFestuca association. It occupies a belt of varying width between the desert scrub formation on the west and the Pacific Coast forest formation on the east. Thus three vegetational frontiers are seen to meet within the region covered by the present investigation. Altitudinally, it occupies an area whose westward boundary has an elevation of $1,200-1,300$ feet, while eastward it reaches an altitude of about 3,500 feet.

The prairies are limited on the east by that combination of climatic and edaphic factors which make tree growth possible, a type of vegetation with which the prairie can not favorably compete. The changed climatic conditions are largely due to increased altitude and are especially expressed in greater precipitation. Likewise, coniferous tree growth is demarked more or less

${ }^{1}$ At the present time, I am not quite clear whether we should properly speak of the prairie-plains formation or whether, indeed, we have here two Festuca lassociations. In any case, the vegetation of the AgropyronAgropyron spicatum more nearly simulates that of the prairies proper, parius east of the mountaing an ecological equivalent of Andropogon sco- 
clearly by the edge of the great lava sheet. Exceptions to this are seen especially along river canyons where xerophytic forest trees, such as pines, may follow down the canyons, and extend out upon the basaltic soils. Indeed, in the canyon of the Palouse River a belt of such woodland extends clear across the prairie community and drops out only at an altitude of 1,450 feet, and where it meets the desert scrub formation. But because of the peculiar rigors that forest frontiers meet, tree species invade the prairie with extreme slowness, notwithstanding the fact that there may be sufficient soil moisture in such situations for the maintenance of a woodland cover.

On its lower and western border the prairie-plains formation gives way to the desert scrub formation. No sharp geographical boundary can be drawn between the two formations. Under the stress of low available soil water, the rainfall being here only I2 to I4 inches, soil depth plays a determining ròle. The prairies, with the loss of their less xerophytic components, extend far westward and to lower elevations upon deep soil. On the other hand, the desert scrub formation, occupying the shallow soils of the scab-lands and rim-rock, may extend far into the prairies. Indeed, about Rock Lake and thence eastward along Pine Creek, the scab-land sage is represented clear to the Idaho boundary. Likewise, it occupies a zone in the warm Snake River Canyon, extending through the prairie region.

As would perhaps be anticipated from the nature of the transition zone occupied by the Agropyron-Festuca association, its composition in the drier portion is strikingly different from that of the well developed upland part. The latter is characterized not only by a greater number of important non-grassy species and a denser plant cover as well as by the absence of certain characteristic desert plants, but also by a change in habit of a dominant grass, Agropyron spicatum (including var. inerme), which under the less xerophytic conditions abandons its bunch habit in part and becomes a sod former. Because of these differences the formation may be separated into a more xerophytic part, the Agropyron consociation, and a less xerophytic Festuca consociation. 


\section{The Festuca Consociation}

This consociation occupies the larger part of the area covered by the prairie-plains formation. Along the thin soils of the canyons the ecotone between this and the Agropyron consociation is often very sharp, but westward and southward it shades imperceptibly into the latter.

The plants that share in the botanical composition of this consociation in eastern Washington and adjacent Idaho are given in the following lists of species which are classified into three groups based upon their relative abundance and ecological importance.

\section{Composition of the Festuca Consociation}

\section{Dominant Species}

Agropyron spicatum (includ- Festuca ovina ingrata ing var. inerme $)^{2}$ Balsamorhiza sagittata Koeleria cristata Poa sandbergii

Principal Species

Achillea millefolium lanulosa Astragalus arrectus Erythronium grandiflorum Geranium viscosissimum Helianthella douglasii Hoorebekia racemosa Hieracium scouleri
Leptotaenia multifida

Lupinus ornatus

Potentilla blaschkeana

Rosa nutkana

Sieversia ciliata

Symphoricarpos racemosus
Agoseris grandiflora

Agoseris heterophylla

Allium acuminatum

Alsine nitens

Antennaria luzuloides Apocynum pumilum

\section{Secondary Species}

Arnica fulgens

Aster fremonti

Aster laevis geveri

Astragalus spaldingii

Bromus brizaeformis

Bromus hordeaceus ${ }^{2}$ The nomenclature in this paper is that of the Flora of Southeastern
Washington and Adjacent Idaho, by C. V. Piper and R. Kent Beattie, 1914. 
Calochortus macrocarpus

Carum gairdneri

Carex geyeri

Castilleja lutescens

Circium foliosum

Circium palousense

Claytonia linearis

Clematis hirsutissima

Cogswellia triternata

Collinsia tenella

Comandra pallida

Deschampsia calycina

Drymocallis convallaria

Elymus glaucus

Epilobium adenocaulon

Epilobium angustifolium

Epilobium paniculatum

Erigeron corymbosus

Fritillaria pudica

Galium boreale

Gaillardia aristata

Gentiana oregana

Gilia gracilis

Heuchera glabella
Hookera douglasii

Iris missouriensis

Limum lewisii

Lithospermum ruderale

Lupinus leucophyllus

Lupinus wyethii

Mertensia oblongifolia

Olsynium grandiflorum

Orthocarpus tenuifolius

Pentstemon confertus

Phlox speciosa

Poa ampla

Senecio atriapiculatus

Sidalcea oregana

Silene douglasii multicaulis

Solidago missouriensis

Synthyris rubra

Trillium petiolatum

Vaccinium caespitosum

Valeriana edulis

Viola adunca

Wyethia amplexicaulis

Zygadenus venenosus

The prairies of eastern Washington, because of their grassy verdure and sod-like appearance in spring and early summer, gave rise to the term Palouse (Fr. pelouse, a land clothed with a short, thick growth of herbage), a name applied by the Jesuit missionaries. However, as the dry summer season progresses the prairies become quite brown and dry, except on the steeper north hillsides and in the moist valleys. The south and southwest slopes present a vegetational cover with a decidedly more xerophytic stamp than the latter situations. Indeed, this is so pronounced that rather careful and extensive investigations of the different habitat conditions were made. Although a part of these results 
have been published elsewhere ( 16,17$)$, it seems well worth while considering them in a brief manner at this time.

Two stations were maintained in these prairies throughout the

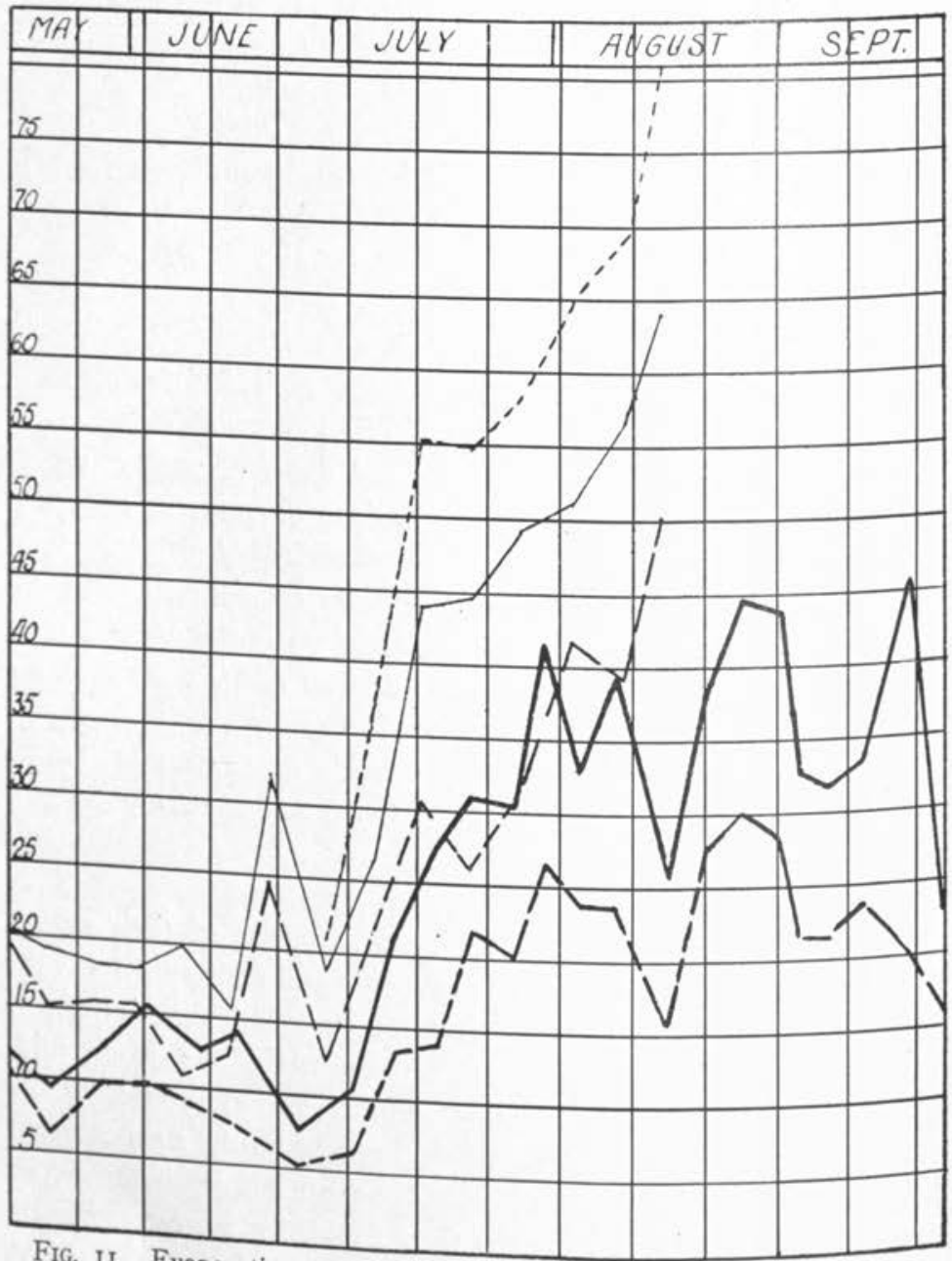

FIG. II. Evaporation rates on a southwest slope (solid lines) and a northeast slope in the Festuca consociation during Igr 3 (heavy lines) and 1914. The dotted graph gives the evaporation rates on the southwest slope and at a height of 50 centimeters during igr 4. 
growing seasons of $1913-14$. One was located on a southwest slope about 65 feet from the crest of a hill somewhat less than the average height, and another at an equal distance from the crest of the same hill and on an average northeast slope. The average daily evaporating power of the air at the two stations respectively is shown in Fig II.

An inspection of these graphs shows a remarkable similarity in the general course of either pair throughout the season. However, the difference in the amount of evaporation on north and south slopes is just as striking. During 1913 the average daily evaporation on the northeast slope was 16 c.c., which is only 64 per cent. of that on the southwest slope $(25$ c.c.). The season of I9I4 was considerably drier and gave higher evaporation rates on both slopes ( 23.9 c.c. on northeast, and 33 c. c. on southwest) with a ratio on the two slopes of $72: 100$.

The evaporating power of the air on the southwest slope and at a height of $50 \mathrm{~cm}$. is also shown in the figure. It may be seen that the evaporating power of the air at this height is increased 20 to 26 per cent. over that at 17 to $23 \mathrm{~cm}$. This factor of increased desiccation plays an important rôle in determining the low stature of many of the prairie plants. Because of the cool nights, about 80 per cent. of these high water losses occur during the day. When we consider that the daily evaporation in July and August often reaches 40 to 55 c.c., and at a time when the available soil moisture is depleted to a depth of two feet, we can see the necessity for extensive root-systems in the substratum as well as aërial structures for enduring drought.

The greatest factor in causing the differences in evaporation on the two slopes is the same one that has so profoundly influenced the topography, namely, the wind. During the season of I9I3 (April 16 to September 3 ) the wind was from a southerly direction 68 per cent. of the time and a total of 13,605 miles passed over the southwest slope at a height of $50 \mathrm{~cm}$., while only 56 per cent. as many miles were recorded by an anemometer similarly placed on a northeast slope. In general, these conditions were duplicated in the season of 1914 with the ratio of $100: 49$. Since the factors of temperature, humidity, and wind movement are 
quite satisfactorily summed up by measuring the evaporating power of the air, the differences of temperature and humidity shown in the two habitats need be discussed only briefly. Although the plant community reacts directly upon temperature, humidity, and wind, and these react upon each other, the response of the plant is controlled by humidity.

The temperature of the air at a height of $8 \mathrm{~cm}$. above the soil surface as recorded by thermographs and checked by a large number of thermometer readings shows a mean daily range varying from about $25^{\circ} \mathrm{F}$. in April and May, to $38^{\circ} \mathrm{F}$. in July and August. The daily maximum air temperature is reached some$2^{\circ}-3^{\circ} \mathrm{F}$. lower.

The steep hillsides are often in the shadow long before the setting of the sun. For long periods during the winter months the sun does not strike the steep north slopes, as is evidenced by the presence of frost, which may soon be melted elsewhere. plete growing seasons shows that the air is often 5-Io per cent. common on dry slopes and during late afternoons for the humidity to fall to $15-20$ per cent., while during the night it may rise again to 75 per cent. or even to 95 per cent.

These data on aërial physical factors show conclusively that the plants on south slopes are subjected to much more severe conditions as concerns water loss than those on sheltered hillsides. Likewise the water supply of the former is usually less and this supply is depleted much earlier in the growing season. Before taking up the subject of soil moisture, however, other important differences in the soil occupying the two slopes should be noted.

The wind has drifted much soil and humus materials from the exposed south slopes and deposited it on the steeper north and northeast leeward slopes. The difference in the mechanical composition of the first foot of prairie soils on the two slopes respectively, is shown in Table II.

all depths humus content of the soils of north hillsides is greater at all depths to 5 feet, in some cases more than 12 per cent. greater, 
than on the exposed slopes, as was shown by six sets of humus determinations made for each foot of soil on the two slopes, respectively. This combination of more clay and more humus on the north and northeast slopes reflects itself especially in the increased water holding capacity of the soil. An average of six determinations gave a mean water holding capacity of 56 per cent. (based on dry weight at $104^{\circ}$ C.) for the first foot of soil on north slopes, as compared with 48 per cent. on south slopes. This margin of 8 per cent. is rather an important difference in favor of the soils on the protected slopes, since the wilting coefficients of the two soils differ but little. These substratum differ-

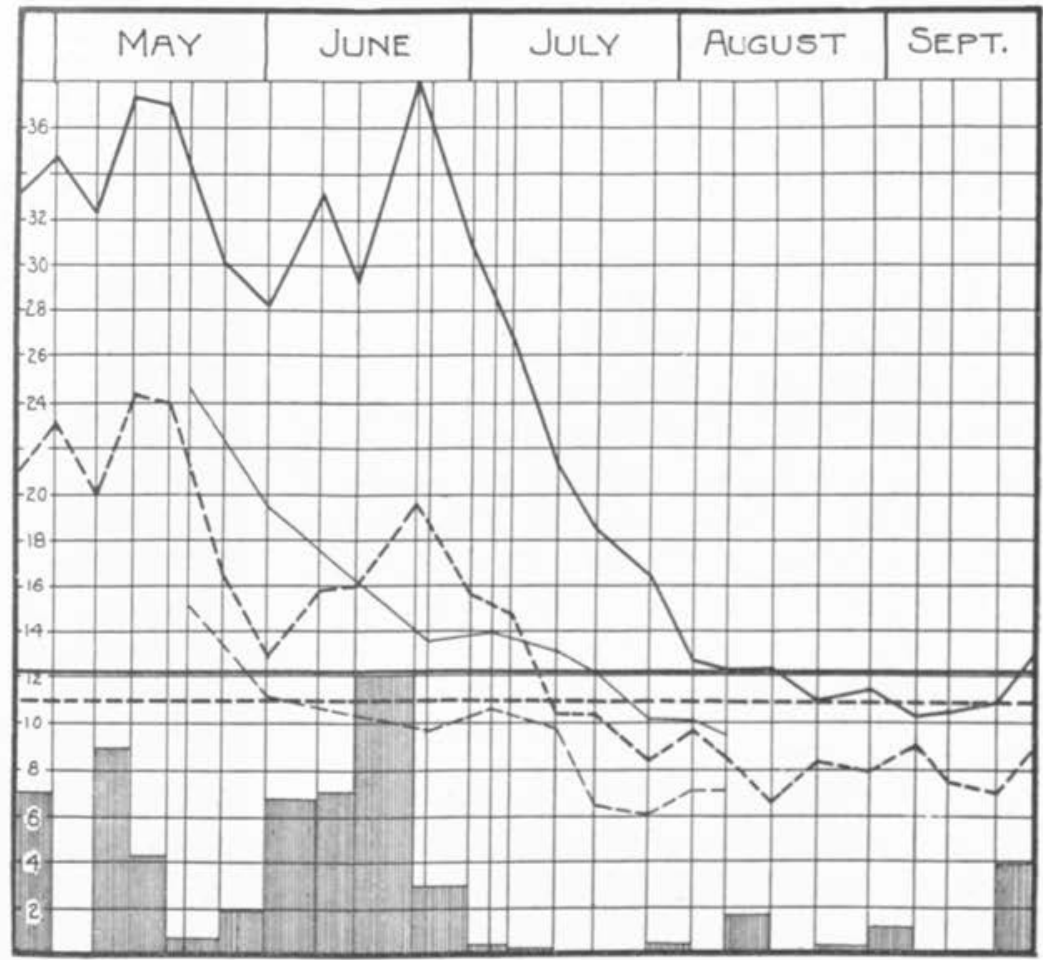

FIG. 12. Graphs showing the march of soil water to a depth of ro inches from April to September, 1913 (heavy lines), and from May to August, 1914, on a northeast slope (solid lines), and a southwest slope, respectively. 
ences are pointed out here since it will be shown later that certain plants are quite confined to moist north and northeast hillsides.

Studies of the water content of these soils have been carried on since the spring of I9I2. It will be unnecessary to burden the reader with all of the data and graphs obtained, and only enough will be given to make plain the seasonal march of soil water. In Fig. I2 are graphs giving the march of soil water from April 25 to September 25, I9I3, on a typical northeast and southwest slope, respectively. The ordinates represent percentages of soil moisture in the first ten inches of soil. The rainfall between the intervals of readings is also shown in inches, each ordinate representing O.I inch. The horizontal solid and broken lines show the wilting coefficients of the soils on the northeast and southwest slopes respectively. The greater amount of moisture on the northeast slope (in some cases being twice that of the southwest slope) may be noted at a glance, while the fact that the soil on the exposed slope reached its wilting coefficient about July I5, and more than five weeks before similar conditions obtained on the sheltered slope is significant. Records for the fall of 1913 were discontinued when the rains of late September replenished tions were soil. In I9I4 these ten-inch soil moisture determinadetermining the only at longer intervals and with the object of The water contents on the wich the wilting coefficient was reached. cated by the light lines, the dates of these determinations are indion the northeast slope. the solid line representing soil moisture proximately normal I9r3) the wilting coefficient r.6 in excess of the mean, as in earlier than in the preceding year. An examination of these shows that at no time after June rainfall records at Pullman, there water available after June 8 and until September I4, was soil on the southwest plant growth in the first ten inches of replenish the soil of the water lost during the long period of
drought and in the following water content. 
It is apparent from these data that prairie plants must obtain their water from greater depths than ten inches, at least during the dry summers. In fact, some of these plants penetrate to a depth of 12 or 13 feet, while most of them get the bulk of their

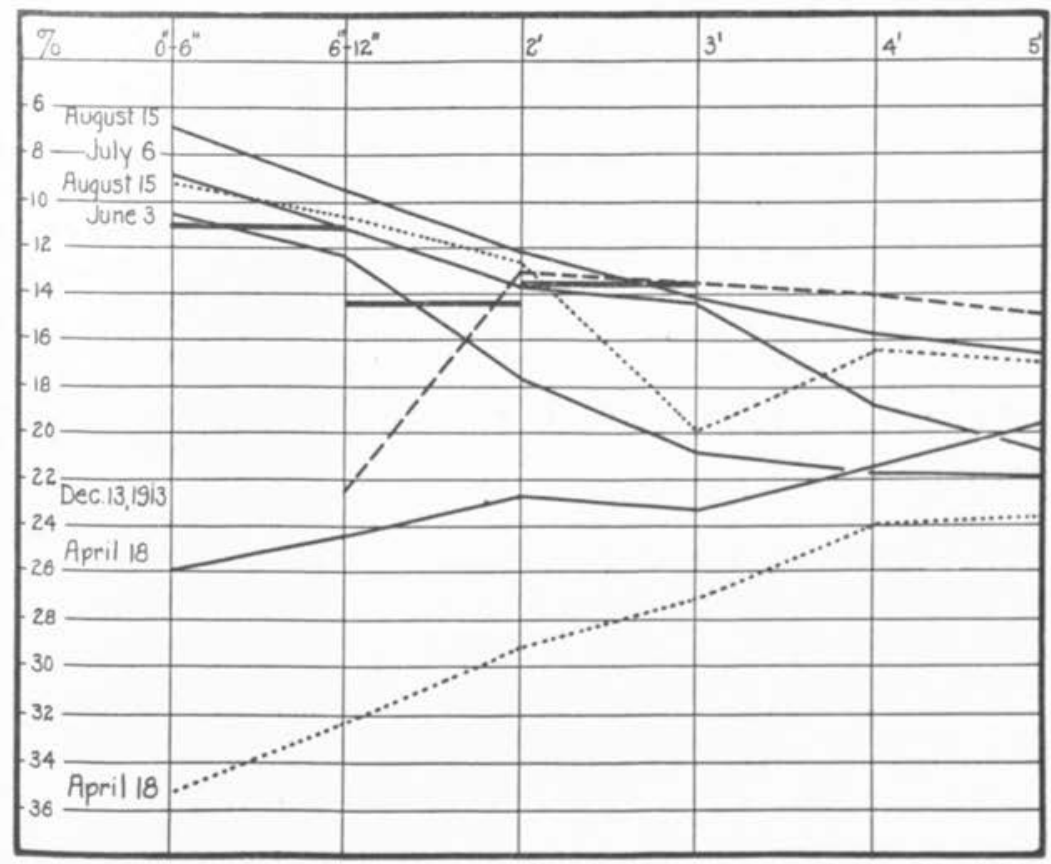

Fig. 13. Graphs showing the march of soil water to a depth of 5 feet on a southwest slope from April 18 to August 15, 1914; and the water content of the soil on December 13,1913 . The dotted lines indicate water contents on a northeast slope.

water from the second to the sixth foot of soil (Figs. $15 a, 15 b$, and ${ }_{15} \mathrm{c}$ ). Consequently, a consideration of soil moisture at these depths is imperative for a proper understanding of root environment. These deeper soil water determinations (many to a depth of 8 feet) were taken at intervals from December, I9I2, to August, 1914. Fig. I3 (solid lines) shows the march of soil water from early spring until late summer of 1914 , on a southwest slope. It is apparent that there was still a downward movement of water 
at depths of 4 and 5 feet after April I8, but from June 3 to August I 5 the soil moisture was gradually depleted at all depths to 5 feet. The heavy horizontal bars give the wilting coefficients at the depths indicated. On July 6 no water was available in the second foot of soil and only a small margin over the wilting coefficient was present at 3 feet. The broken line indicates that on December $\mathrm{I} 3$ of the preceding winter the soil was drier at three, four, and five feet respectively, than at any other time indicated. The fall rains had not then penetrated beyond 2 feet. While excavating root-systems during the fall, winter, and spring, an excellent opportunity was offered to study the rates of penetration. The water penetrated very slowly and at about equal rates on all slopes. By October 18 only the surface layer of 8 inches was wetted, and in late March the wet soil reached a depth of not more than 4 feet. The dotted graphs in the figure indicate the soil moisture on the northeast slope.

Aside from the lower temperature and greater humidity of the north slopes, the actual amount of moisture available to these soils is important in explaining the observed differences in moisture content. The wind drifts over to the sheltered slopes much snow, which upon melting adds to the soil water. Two examples will suffice. In February, 1914, exposed prairie slopes had a blanket of snow from 5 to 8 inches deep, while on the sheltered slopes at the same time drifts 48 to $5^{2}$ inches were measured. The second, while an extreme case, is illustrative. During February and March, I9I3, while only one foot of snow lay on the south and southwest slopes, the protected northeast slopes were covered with drifts of well-packed snow from to to 13 feet deep.

In Fig. 14 is shown the march of soil water similar to that in the preceding figure, but for soils of a northeast slope. Here again, the downward movement of water at 3-5 feet after April 18 is apparent, as is also the gradual depletion of soil water at all depths to 5 feet. Likewise, the broken graph indicates conditions similar to those explained for the corresponding graph in Fig. 14. On August I5 no soil water was available above the two-foot level. If the graphs in this figure are compared with the corresponding graphs in the preceding one it may be readily 
seen that a much higher water content was maintained in the soils on the northeast slope.

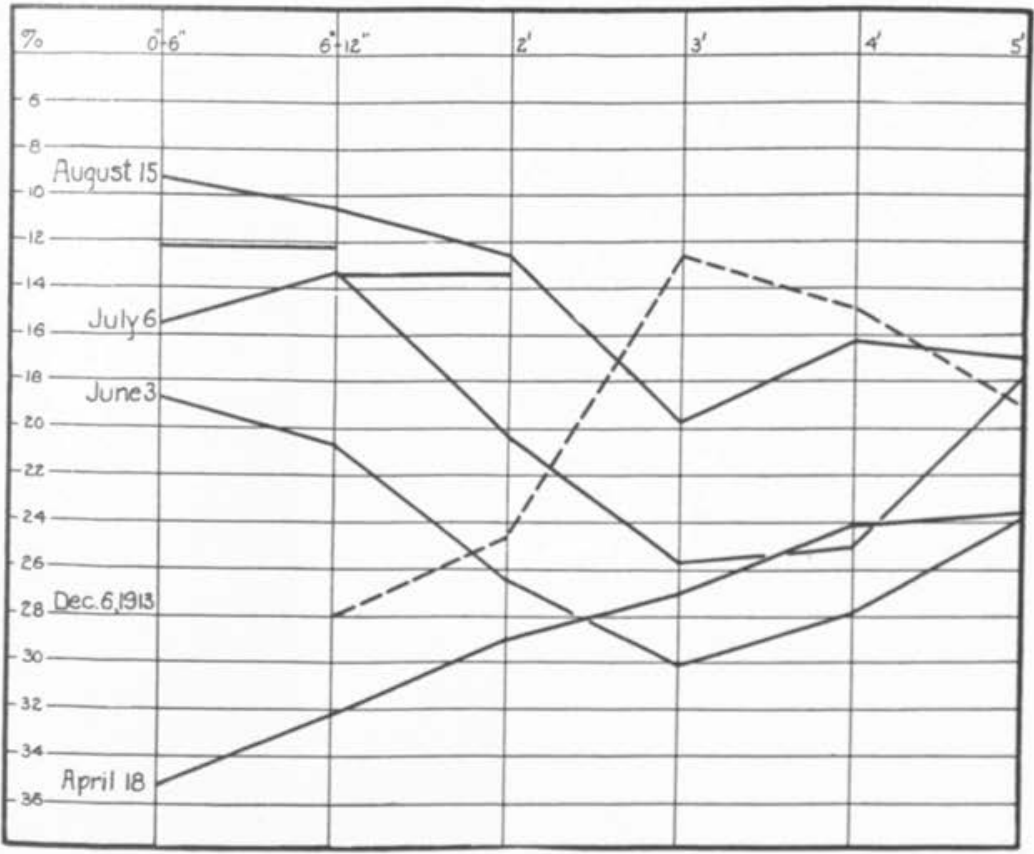

FIG, 14. Graphs showing the march of soil water to a depth of 5 feet on a northeast slope from April 18 to August 15, 1914, and the water content of the soil on December 6, 1913.

In order to further check these deep soil water conditions samples were again taken in duplicate on the northwest and south slopes of another prairie-covered hill. These findings, indicated in Table VI, check very closely with the preceding, and the striking difference between soil water content on the two hillsides at all depths is well shown.

It may also be noted that at each determination the soil at any depth was drier than at the same depth at the time of the preceding determination. On the south slope, it is interesting to note that without exception, the soil moisture increased with depth, and that the same condition maintains in most cases for north-side soils. 
Thus it may be seen that topography with soil texture is the great middleman that distributes the soil moisture to fill the gigantic earthen reservoir, which again is largely emptied during the following growing season. The common farm practice in the Palouse Region of alternating season after season the growing of wheat with summer fallow, is a method of storing the moisture from one year for use in the growth of the next year's crop.

\section{TABLE VI}

The March of Sorl Water on a Northwest and South Slope RespecTIVELY. I9I4

\begin{tabular}{|c|c|c|c|}
\hline 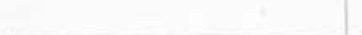 & May 22 & July 6 & August 15 \\
\hline$o^{\prime \prime}-6^{\prime \prime}$ N.W............ & $23.4 \%$ & I 5.2 & 11.6 \\
\hline S. $\ldots \ldots \ldots \ldots \ldots \ldots$ & I 2.5 & II.I & 6.7 \\
\hline $6^{\prime \prime}-12^{\prime \prime}$ N.W. . . . . . . . . & 25.7 & 13.7 & I2.I \\
\hline $\mathrm{S} \ldots \ldots \ldots \ldots \ldots \ldots \ldots$ & 17.9 & II. 4 & 10.2 \\
\hline At $2^{\prime} \quad \mathrm{N} . \mathrm{W} \ldots \ldots \ldots \ldots \ldots$ & 27.0 & 18.9 & II. 8 \\
\hline 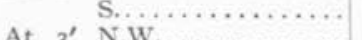 & 19.9 & 12.6 & 10.2 \\
\hline At $3^{\prime} \quad \mathrm{N} W \ldots \ldots \ldots \ldots \ldots \ldots \ldots$. & $\begin{array}{l}30.2 \\
20.2\end{array}$ & $\begin{array}{l}23.7 \\
\mathrm{I} 3.2\end{array}$ & $\begin{array}{l}14.4 \\
10.6\end{array}$ \\
\hline At $4^{\prime} \quad \mathrm{N} . \mathrm{W} \ldots \ldots \ldots \ldots \ldots$ & 27.2 & 24.9 & 18.0 \\
\hline At,$\quad$ S. $\mathrm{s}^{\prime} \cdots \cdots \cdots \cdots \cdots$ & 22.0 & I 7.3 & 10.5 \\
\hline 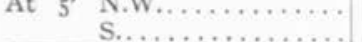 & 24.3 & $2 \mathrm{I} .3$ & 19.5 \\
\hline $5 \ldots \ldots \ldots \ldots \ldots \ldots$ & 22.4 & I9.6 & I 2.3 \\
\hline
\end{tabular}

The differences in soil temperature on the two slopes and at various depths may be briefly noted here. Table VII gives the soil temperature at a depth of 3 inches on the two slopes respectively, for three representative days in July, 1914. The higher temperature prevailing on the south slope as well as the greater range in temperature is very marked.

\section{TABLE VII}

Soll Temperature at a Depth of 3 Inches

\begin{tabular}{|c|c|c|c|c|c|c|}
\hline Station & Minimum & Time & Maximum & Time & Range & Day \\
\hline $\begin{array}{l}\text { N.E. slope } \ldots \ldots \\
\text { S.W. slope } \ldots \ldots \\
\text { N.E. slope } \ldots \ldots \\
\text { S.W. slope } \ldots \ldots \\
\text { N.E. slope } \ldots \ldots \\
\text { S.W. slope . . . . }\end{array}$ & $\begin{array}{l}63.5^{\circ} \mathrm{F} . \\
57.0 \\
59.0 \\
68.0 \\
61.0 \\
67.0\end{array}$ & $\begin{array}{c}\text { A. M. } \\
5 \\
7 \\
5 \\
7 \\
5 \\
7\end{array}$ & $\begin{array}{l}75.0 \\
93.0 \\
71.5 \\
94.0 \\
73.5 \\
95.0\end{array}$ & $\begin{array}{c}\text { P. M. } \\
3 \\
4 \\
3 \\
4 \\
3 \\
4\end{array}$ & $\begin{array}{l}11.5 \\
26.0 \\
11.5 \\
26.0 \\
12.5 \\
26.0\end{array}$ & $\begin{array}{ll}\text { July } & 27 \\
\text { July } 27 & \\
\text { July } 28 \\
\text { July } 28 \\
\text { July } 29 \\
\text { July } 29\end{array}$ \\
\hline
\end{tabular}


A comparison of a large number of temperature readings at one foot on the two slopes reveals the fact that at this depth the soils on the south slopes are from $3^{\circ}$ to $5^{\circ} \mathrm{F}$. warmer in early spring than those on the north slopes and that these differences may increase by late summer to $7^{\circ}-10^{\circ} \mathrm{F}$. In Table VIII the soil temperature from $I$ to 5 feet on the two slopes at the base station is given.

\section{TABLE VIII}

Soll Temperature at I-5 Feet on April 18 and August 15, 1914, on A Northeast and Southwest Slope, Respectively

\begin{tabular}{|c|c|c|c|c|}
\hline \multirow{2}{*}{ Depth } & \multicolumn{2}{|c|}{ April 18} & \multicolumn{2}{|c|}{ August 15} \\
\hline & N.E. & s.w. & N.E. & S.w. \\
\hline 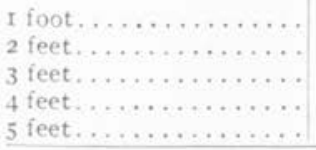 & $\begin{array}{l}45.7^{\circ} \mathrm{F} . \\
45 . \mathrm{I} \\
45.0 \\
45.0 \\
45.0\end{array}$ & $\begin{array}{l}50.3 \\
50.0 \\
48.2 \\
47.0 \\
46.4\end{array}$ & $\begin{array}{l}65.0 \\
61.7 \\
58.0 \\
57.2 \\
54.5\end{array}$ & $\begin{array}{l}73.0 \\
70.0 \\
66.2 \\
64.4 \\
62.6\end{array}$ \\
\hline
\end{tabular}

The higher soil temperature prevailing on the south slopes has much to do with the earlier seasonal activities of many plants here than of those on north hillsides.

Summarizing briefly the habitat conditions in the prairie, we find the north and northeast slopes less xerophytic than the south and southwest slopes. This is due in part to actually greater precipitation caused by blowing snow, and in part to soil texture, which is more open, has more humus, and a greater water holding capacity. These factors are reflected in the greater amount of soil water and in lower temperatures. Likewise, these slopes are sheltered from the drying southwest winds, and from the perpendicular rays of the sun. This is reflected in slightly lower air temperature and greater humidity, and especially in the lower evaporating power of the air.

These differences in habitat are reflected in the vegetational cover in a number of ways. The resumption of growth in late March or early April is often from ro to 17 days earlier on the warmer exposed slopes. Likewise, the same species flower and dry up correspondingly earlier than on the sheltered slopes. The vegetational cover is less dense on the exposed slopes, often ro to. 
30 per cent. of the ground appearing bare by mid-summer. Closer investigation, however, reveals that much of this space was formerly occupied by prevernal and vernal plants which have by this time become dry and brown. However, relict xerophytic mosses and lichens indicate the more open nature of the ground cover.

A careful census of the plant population consisting of scores of list quadrats reveals striking differences, not only in the number of individuals, but also in the floristic distribution of species. On an average it was found that south slopes are clothed with about II $_{5}$ individuals per square meter, while the north slopes, with only about 3 per cent. of unoccupied soil space, showed more than 200 individuals in the same unit area.

Perhaps the most pronounced difference is the smaller number or total absence of more mesophytic plant-forms which thrive in moist situations. Erythronium grandiflorum, Trillium petiolatum, Capnorea villosula, Vaccinium caespitosum, and Viola adunca are examples of species characteristic of moist north hillsides. Numerous species, such as Sidalcea oregana, Circium foliosum, Valeriana edulis, Gentiana oregana, and others seldom occur on south slopes.

The blue bunch-grass, Festuca ovina ingrata, ranking in importance with Agropyron spicatum, is the most characteristic grass of the region (Fig. 48). The slightly pale-green plants are densely tufted into bunches from I to 4 inches in diameter. The low, bushy, setaceous leaf blades scarcely exceed a height of 12 inches. It is not unusual to find as many as ro to 13 of these bunches in a single square meter. The bunch habit, an aspect of prairie vegetation which is found more or less developed in practically all prairie regions, and one which has succeeded in a remarkable degree in withstanding xerophytic conditions, is most pronounced on the drier slopes. In moist situations the clumps are smaller, but I have never found Festuca producing rhizomes. Like the other prairie grasses Festuca flowers by the middle of June. Since its root-system draws the water supply from the upper I 8 inches of soil, its drying out in July and resumption of growth upon the arrival of the autumn rains can easily be accounted for. 
The June grass, Poa sandbergii, one of the pioneers of herbaceous vegetation in the moss consocies, is also perhaps one of the most important interstitial plants of the prairies. It grows in small tufts usually only about 0.5 to 1.5 inches in diameter but as many as 30 to 40 of these may occur in a single minor quadrat between the bunches of Festuca and Agropyron. It is called June grass because of its habit of flowering in May or early June and remaining dormant until the advent of the fall rains. This means of evading drought is necessitated by its very shallow root-system, which seldom exceeds 8 inches. Its xerophytic tendencies are shown by its less abundance in mesophytic situations.

The sod-forming habit of Agropyron spicatum in the prairies of eastern Washington is in marked contrast to its well developed bunch habit on the rim-rock or in the shallower and drier soils westward. I have found the soil quite filled with rhizomes of considerable length connecting smaller clumps of this grass. It may well abandon this marked xerophytic character, for its long roots extend into the fourth and fifth foot of soil, and tap the earthen reservoir far below the root limits of competing grass species.

Another common bunch-grass, which, with the three preceding, completes the list of dominant grass species, is Koeleria cristata. Like Poa, the bunches are often small, but numerous. It completes flowering in early July and remains dormant until revived by the autumn rains. Its well developed but short root-system gets water from the first $\mathrm{I}_{5}$ inches of soil only.

The entire absence of late blooming grasses, such as $A n$ dropogon, Sorghastrum, Boutelou, and others of the prairieplains region, may be accounted for by the peculiar distribution of the precipitation.

A most characteristic plant of the prairies, and one which for a time often outranks the grasses, is the prairie sunflower, Balsamorhiza sagittata (Fig. 42). Its abundance, size, and duration all unite to make it a very important ecological species. It is not unusual to find a dozen of these plants in an area of four square meters. Only on the steeper northeast slopes and moist valleys 
is it absent. A medium-sized mature plant occupies an area of 4-5 square feet; it may have as many as $50-80$ of the large sagittate leaves and a total transpiring surface of 30 square feet. From the short, thick, multicipital stem (I have counted 39 individual leafy shoots on a stem 9 inches in diameter) the new leaves appear in April. By the first of May the plant is often in full bloom. Then, with its large, yellow flowers, it is the most conspicuous object of the vernal aspect, which lasts until about June I. After this

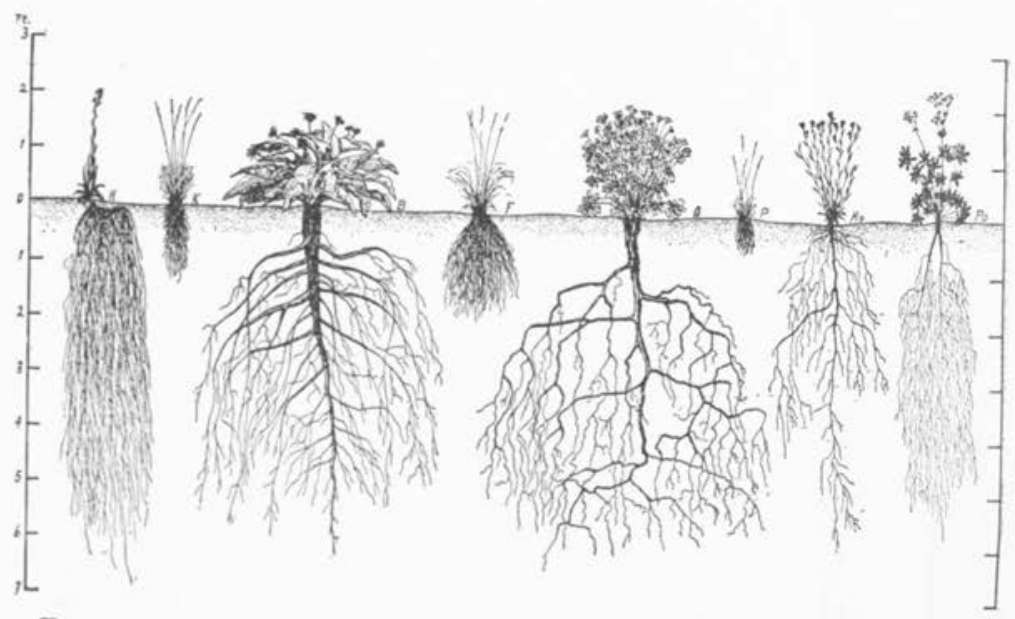

FIc. $15^{a}$. This and the two following figures $\left(15^{b}\right.$ and $\left.15^{c}\right)$ are bisects showing the root and stem relations of important prairie plants. These figures were drawn from photographs and from data obtained by the excavation and examination of 325 root-systems of these eighteen species. $H$, Hicracium scouleri. $K$, Koeleria cristata. B, Balsamorhiza sagittata. $F$, Festuca ovina ingrata. G, Geranium viscosissimum. P, Poa sandbergii. Ho, Hoorebekia racemosa. Po, Potentilla blaschkeana.

the whole aërial part dries up, but the dead leaves are conspicuous throughout the year. It has a strong, woody tap-root, sometimes reaching a diameter of 4 inches, which may penetrate into the soil for a distance of 8 feet. Not only is it deep-rooted, but the extensive and wide-spreading laterals lay hold upon a very large
area of soil.

In another place will be found a detailed report of a study of 56 
the root-systems of many of the most important prairie plant species and it is there pointed out that the response of many of the plants to severe environmental conditions is met by well developed and extensive root-systems (17). Figs. $15 a, 15 b$, and ${ } 5 \mathrm{C}$ show in part the results of these investigations as regards root type and depth of penetration.

Standing well above most other prairie vegetation and conspicuous not only for its size but also often for its great abundance is Leptotaenia multifida. This large, much branched, unbelliferous plant occurs quite commonly on both dry and moist

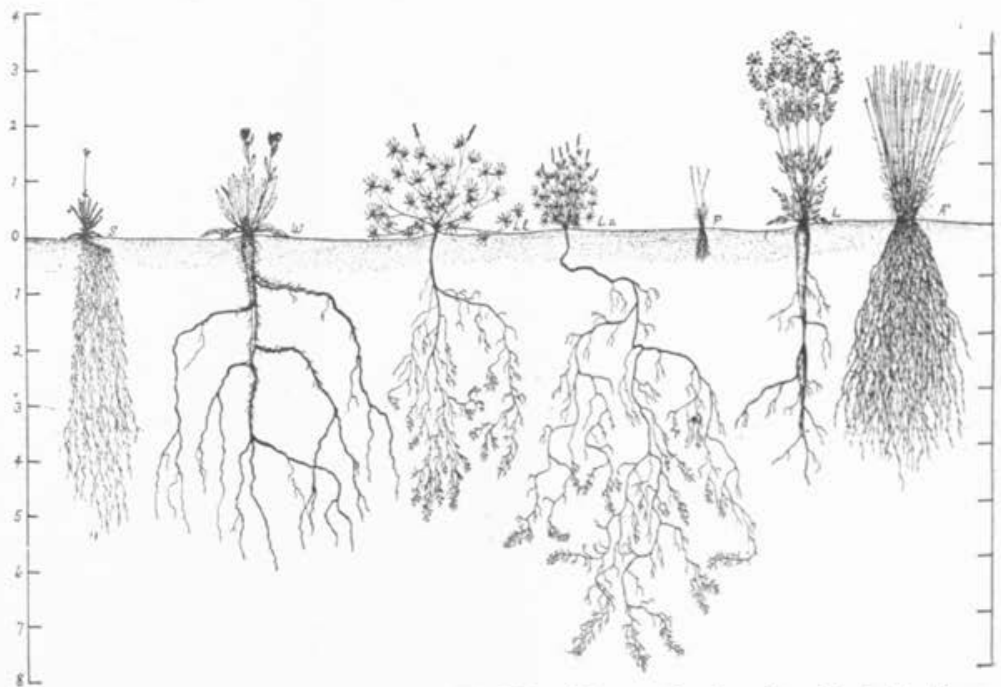

FIG. $15^{b}$. S, Sieversia ciliata. W, Wyethia amplexicaulis. L. l, Lupinus leucophyllus. L. o, Lupinus ornatus. P, Poa sandbergii. L, Leptotaenia multifida. A, Agropyron spicatum.

hillsides. It often characterizes rather large areas, but even if occurring sparsely it is nevertheless very conspicuous and especially in June, when, after flowering, the leaves turn yellow before drying up.

Erythronium grandiflorum constitutes a well-marked prevernal aspect society on moist north hillsides from early April to the first week in May. Even before the plants open their large golden 
yellow blossoms, their great numbers, often more than Ioo individuals in a square meter, give a distinct tone in contrast to the gray background of dead vegetation.

Later on by the blossoming of Amelanchier, Crataegus, Prunus, and Rosa especially, the developmental shrub community becomes very conspicuous. But the prairies become veritable flower gardens during the month of June. Then the large red

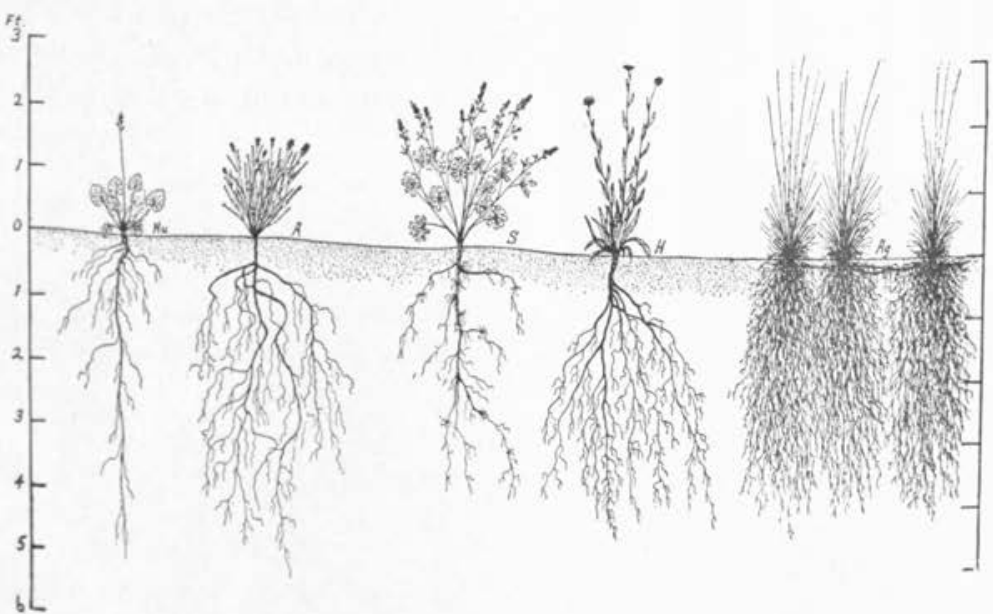

Fic. I5 $^{\circ} . H u$, Heuchera glabella. A, Astragalus arrectus. S, Sidalcea oregana. $\mathrm{H}$, Helianthella douglasii. Ag, Agropyron spicatum.

blossoms of Geranium and Rosa mingle with the yellow of Potentilla, Gaillardia, Castilleja, and Helianthella. Senecio, Astragalus, Arnica, and societies of Wyethia brighten the landscape with their yellow blossoms, while the tall, widely spaced, sentinel-like plants of Cirsium foliosum with their showy red flowers add pleasing variety.

Likewise the purple flowers of various lupines are conspicuous. Lupinus wyethii is only locally abundant. It is especially noticeable in the vernal aspect. It often covers areas of the driest hillsides and the whole aërial part dries up early. Lupinus ornatus is very cosmopolitan over the high prairies and is an important species. Lupimus sericeus is confined to the warmer 
valleys southward and westward. Here its size and abundance make it an important floral component. Lupinus leucophyllus is the most mesophytic of the group and is found at home typically on moist north slopes or in the valleys.

In the lower ground considerable areas are given tone by the white flowers of Galium. But with the increasing stress of drought the aestival aspect passes, lingering only in moister situations. Then the leaden landscape of dry balsam-root, drying grasses, and silvery-leaved lupines and hawkweed is relieved only by the yellow and the blue of sparsely spaced goldenrods, asters, and Hoorebekia.

I have described very briefly the well developed prairie represented by the Festuca consociation. Westward and southward as the altitude decreases and the rainfall is correspondingly less, many important species either become fewer in individuals, or are found only in the most mesophytic situations, or indeed disappear entirely. Among these the following may be enumerated:
Astragalus arrectus
Carex geyeri
Cirsium foliosum
Drymocallis convallaria
Gaillardia aristata
Galium boreale
Geranium viscosissimum
Helianthella douglasii
Heuchera glabella
Hieracium scouleri
Hoorebekia racemosa

Leptotaenia multifida

Lithospermum ruderale

Potentilla blaschkeana

Rosa nutkana

Rosa pisocarpa

Sidalcea oregana

Sieversia ciliata

Symphoricarpos racemosus

Trillium petiolatum

Viola adunca

Wyethia amplexicaulis

\section{The Agropyron Consociation}

This community in an early stage of development covers hundreds of acres of the thin soil in the scab-lands. The characteristic plant is Agropyron spicatum. Areas characterized by this consociation are peculiar because of the growth form of the dominant species as well as a number of the commoner interstitials which show various degrees of the same bunch habit. Numerous 
other plants are mat-formers, while a few are more or less shrubby in character.

The bunches of Agropyron are often I-2 feet apart, perhaps only $2-5$ occurring in a square meter (Fig. 47 ). The individual bunches or tufts are composed of from 100-350 or more stiff, erect stems, reaching a height of $2-3$ feet. Several generations of dead stems are to be seen in these persistent bunches, the old leaves and culms forming a tangle at the bushy base. Consequently the landscape appears just as characteristic in late summer when this dominant is drying out as in the fall when it takes on renewed growth, or in early spring when a host of interstitials for a time cover the ground with a green carpet. Agropyron is the one grass best adapted for such situations. Its well developed roots penetrate the moist crevices in the underlying basalt to a depth of 4 or 5 feet.

Grasses like Festuca ovina ingrata and Koeleria cristata with rather short root-systems find this an uncongenial habitat. However, a few grasses with very short root-systems and an early blooming habit are very successful interstitials. Of these, Poa sandbergii and the low annual, Festuca pacifica, are by far the most important. Hundreds of individuals of the latter frequently occur in a single square meter. Mats of Antennaria dimorpha and dense growths of Plantago purshii are likewise common between the scattered bunches of the dominant. These
interstitials, together with numerous others are quite as common in the preceding Poa-Polygonum associes of which this, indeed, late for the dominance of Agropyron, might be considered a late developmental stage. However, the presence of the rabbit canescens, Erigeron hispidissimus, C. viscidiflorus, Tetradymia cially in pockets of deeper toward the more typical soil, indicates the developmental trend

In the deep soils of the hills byron community. pyron consociation is better developed the scab-lands the Agroance of Festuca ovina indicates Indeed, the latter someticates more favorable life conditions. Agropyron on the more moist assumes equal importance with 
unoccupied soil surface, from 30 to 40 per cent., and the appearance of several new species of a decidedly xerophytic stamp gives this consocies quite a different physiognomy from the well developed prairies eastward. The following lists indicate the dominant, principal, and secondary species:

Composition of the Agropyron Consociation

\section{Dominant Species}

Agropyron spicatum

$$
\text { Principal Species }
$$

Achillea millefolium var. lanulosa

Chrysothamnus nauseosus

Chrysothamnus nauseosus graveolens

Chrysothamnus viscidiflorus

Festuca ovina ingrata

Lupinus ornatus

Lupinus sericeus

Poa ampla

Poa sandbergii

Tetradymia canescens

Festuca pacifica

Secondary Species

Agoseris heterophylla

Epilobium paniculatum

Allium acuminatum

Alsine nitens

Antennaria dimorpha

Artemisia rigida $^{3}$

Astragalus collinus

Erigeron corymbosus

Erigeron hispidissimus

Eriophyllum lanatum

Astragalus spaldingii

Balsamorhiza sagittata

Gilia pharnaceoides

Koeleria cristata

Carex filifolia

Cirsium undulatum

Clarkia pulchella

Cogswellia triternata

Elymus condensatus

Lupinus wyethii

Madia exigua

Madia glomerata

Phlox longifolia

Plantago purshii

Potentilla biennis

Stipa comata

The rabbit brush, although more common westward, is an abundant and conspicuous component of the bunch-grass community.

${ }^{3}$ Relict. 
Its shrubby growth-form, numerous, erect, fascicled, and dense, white-woolly branches and white-woolly leaves, combined with a greater height-growth than most of its associates, make it a conspicuous plant in the landscape. The non-woolly variety, Chrysothamnus nauseosus graveolens, not less conspicuous, is also very abundant. Both plants extend well up the warm valleys and canyons but are practically absent from the high prairies eastward.

Tetradymia canescens, with a growth form similar to the preceding half-shrubs, likewise lends a decidedly xerophytic tone to the dry scab-lands. It reaches its eastward extension in this
region.

A plant which forms a rather distinct consocies is Elymus condensatus. On moist flood-plains this grass reaches a height tufted and areas of many acres may be dominated by this species. In deep soils on the dry hillsides it is not infrequent, but here it usually occurs in more or less isolated clumps.

In the eastward extension of the Agropyron community along the rim-rock of the streams into higher altitudes, many of the species being confined to the warmer valleys, drop out. In such bunches of Aalsamorhiza sagittata is often abundant between the In Agropyron.

live typically not only in a climate the plants of this consocies which the period of drought, ow of lower rainfall but also one in growing season severought, owing to the warmer climate with a as compared with that of the well is correspondingly increased higher altitudes.

In the preceding pages I have treated the Festuca and Agrotion, faven commities as climax units of vegetation. Without question, favorable changes of climatic conditions, such as a slight inmunity into the area now an extension of the Festuca comtion. The latter in now occupied by the Agropyron consociawestward into the desert scrubld extend its area downward and ments of plant populations scrub formation. Indeed, such moverim-rock and scab-land 
of favorable modifications of the edaphic conditions such as an increase in amount or an increase of the water holding capacity of soils.

Likewise, on its high eastern border the Festuca consociation contains a potential shrub community. Almost everywhere Symphoricarpos, Rosa, and Spiraea are present but are held in check by competing herbs and grasses. A local disturbance of the habitat such as the building of a fence or the burrowing of squirrels modifies it favorably by increasing the water holding capacity of the soil and swings the balance in favor of the shrubs. Once established the shrubs may furnish a suitable nursery for seedlings of the yellow pine and thus the prairie may give way to forest. These modifications of edaphic conditions foreshadow those which would be caused by a favorable swing of climate, while the reverse of these conditions would follow an unfavorable change. Indeed, the balance between prairie, shrub, and forest is so nicely adjusted that even a few years of exceptionally dry or unusually wet weather would be recorded in the movements of the vegetation.

The seral stages of the Agropyron-Festuca association will next be considered, and in this place we shall discuss those of the xerosere only. This will be followed by a brief treatment of the desert scrub formation, after which the xerosere will be traced to its culmination in the climax cedar forest.

(See outline of vegetational units, page r9.)

\section{LICHEN-MOSS COMMUNITIES}

Where the basaltic rock is exposed along the canyon walls and in the scab-lands, as well as upon outcropping ledges of crystalline rocks on buttes and mountains, a flora of lichens and mosses abounds. During the dry summer months the rocks appear quite bare and devoid of vegetation, but upon the advent of the autumn rains, not only lichens and mosses, but also the June grass, which closely follows the latter in point of succession, takes on renewed growth. Then these situations, with their new verdure, become quite inviting. Three associes are easily distinguishable, of which that dominated by various crustose lichens is the pioneer. 
of succession. Starting from the vantage ground of a crack or crevice, the small tufts collect wind-blown soil and lichen remains about them and building upon this substratum increase their area. Well-worn rocks are frequently covered with the black mats of the Grimmia consocies.

Less xerophytic but far more abundant is Tortula ruralis. Growing in places less dry than those occupied by Grimmia, it surrounds the base of rocky outcrops and occurs on thin stony soil where its soft cushiony mats may cover areas of many square meters. While Tortula is very abundant on basaltic ledges it is sometimes partly or wholly replaced, especially about quartzite rocks, by species of Polytrichum, especially $P$. piliferum and $P$. juniperinum.

In other situations, and especially on canyon walls with north and northeast exposure other mosses are abundant, often covering large areas of sheer rock surface or growing luxuriantly over the thin stony soil. The following lists include the most important of these together with a number of lichens which usually occur with the mosses. Some of these lichens are less xerophytic than the foliaceous forms already mentioned. Indeed, they are the most exacting members of the foliose lichen community.

Brachythecium albicans

Brachythecium erythrorrhizon

Camptothecium aeneum

Camptothecium lutescens

Cladonia pyxidata

Diploschistes scruposus

Ceratodon purpureus
Encalypta ciliata
Grimmia apocarpa
Mnium affine

Ochrolechia upsaliensis Peltigera canina

\section{Poa-Polygonum Associes}

In the thin soil between the fragments of broken rock, an area over which Tortula ruralis and other mosses for a time have control, bunches of June grass and plants of Polygonim majus and Plantago purshii begin to appear (Fig. I8). Changes of while shallow-rooted plants are well adapted to dominate just 
such areas. The broken rock fragments not only aid in the percolation of water and prevent run-off, but also tend to reduce evaporation.

The xerophytic character of Poa sandbergii has been discussed. Poligonum majus with its wiry stems and diminutive leaves answers well ecologically for a grass. Likewise, the linear-leaved, spiked, densely hairy Plantago may be so considered.

Polygonum majus must be a plant of very low water requirement for, in spite of its shallow roots, it blossoms and appears to thrive throughout the summer and fall in these stony soils. It is especially noticeable among the rocks when most other plants are dried out, and its abundance makes it showy notwithstanding its tiny flowers. I have counted more than $\mathrm{I}, 000$ individual plants from 2-8 inches high in a single square meter. In deeper soils of talus slopes it becomes a bushy plant, sometimes more than a foot in height.

In the scab-lands especially, Plantago purshii characterizes large areas with its leaden color.

The following plant lists include those especially characteristic of this community:

Composition of the Poa-Polygonum Associes

Dominant Species (Consocies)

Plantago purshii

Polygonum majus

Poa sandbergii

\section{Principal Species}

Antennaria dimorpha

Antennaria luzuloides

Clarkia pulchella

Cogswellia grayi

Cogswellia gormani

Secondary Species

Agoseris heterophylla

Agoseris grandiflora
Eriogonum heracleoides

Epilobium paniculatum

Festuca pacifica

Madia exigua

Madia glomerata
: Allium acuminatum

Alsine nitens 
Alyssum alyssoides

Arabis sparsiflora

Arabis holboellii

Athysanus pusillus

Bromus brizaeformis

Cogswellia macrocarpa

Draba verna

Eriogonum niveum

Eriogonum compositum
Festuca megalura

Platyspermum scapigerum

Ranunculus glaberrimus

Sedum douglasii

Selaginella wallacei

Tellima tenella

Tellima parviflora

Thysanocarpus curvipes

A number of the above species form more or less well developed socies. Cogswellia gormani, one of the earliest of prevernal plants, though inconspicuous as an individual, grows in such great numbers on the thin soils as to become quite prominent in early spring. When $500-800$ of these plants occur in a square meter, as is often the case, with perhaps a third of them in blossom, they indeed make the landscape appear as if covered with "salt-and-pepper."

Cogswellia grayi is much more important than C. gormani. It covers large areas of rim-rock almost to the exclusion of other species. Its large umbels of yellow flowers make it very conspicuous.

Moist places on the thin soils are dominated for a time in early spring by great patches of Ranunculus glaberrimus, a small plant but one with large and showy flowers.

The Poa-Polygonum associes gives way to the community dominated by Agropyron. The chief cause for the transition is the accumulation of soil and the presence of rock crevices of sufficient depth and width to furnish soil and water for the deeprooted bunch-grass. The early stage of the Agropyron consociation, already described, well illustrates this change. Often however, in the rim-rock throughout the less arid region, the transition is more abrupt. Belt transects only a few meters long often show zones of vegetation dominated by the characteristic species of the Poa-Polygnum, Agropyron, and Festuca communities respectively. These zones extend in a parallel manner along the upper edge of rocky outcrops. Below the transition 
may be even more abrupt, a linear distance of one or two meters giving the necessary differences in soil depth. Consequently the zones are narrower, but no less distinct.

The uneven disintegration of canyon walls and scab-land and rocky butte ledges and the differences they offer in slope and exposure and in depth and moisture of soils furnish so many habitat conditions that perhaps two-thirds of the total flora find here more or less congenial homes. In the crevices of a lichencovered rock and separated only a few inches from the lowly inhabitants of the former may thrive a shrubby member of a far more advanced community. An analysis of the habitat shows each is growing in its proper place, the crustose lichen on the bare rock, the shrub in a small area of rich, well moistened soil.

Striking differences are offered by habitats on sheltered and protected slopes. Near Pullman, during the summer of 1913 , a station was maintained on a south slope in the Agropyron community and a second in a rather open growth of low shrubs on the opposite slope about half-way between the rock ledge and the flood-plain thicket. Not only was the evaporating power of the air found to be twice as great in the former situation, but the soil moisture was only about half as great throughout the growing season. Temperature differences were also striking. The soil between the bunches of Agropyron frequently gave noonday temperatures of $90^{\circ}$ to $100^{\circ} \mathrm{F}$, as compared with $70^{\circ} \mathrm{F}$. at the opposite station.

These illustrations of diverse habitat conditions will make plain the fact that in addition to the plants already mentioned as belonging to the Agropyron or Poa-Polygonum communities, many others occur.

Characteristic shrubs and lianas found either as crevice plants on rocky talus slopes or forming thickets about springy places are enumerated in the following lists: the numerals indicate their relative importance. In the drier regions the shrubs are notably fewer.

Amelanchier florida 2 Amelanchier cusickii $\mathrm{I}$
Berberis repens $\mathbf{I}$

Clematis ligusticifolia 2 
Crataegus columbiana 2

Opulaster pauciflorus 2

Philadelphus lewisii I

Prunus demissa $\mathrm{I}$

Rhus glabra 2

Rhus toxicodendron 2

Ribes aureum 2
Ribes cereum $\mathrm{T}$

Ribes cognatum 2

Rosa mutkana I

Rosa pisocarpa 2

Sambucus glauca 2

Spiraea corymbosa 2

Symphoricarpos racemosus I

In springy places among the rocks, which are often, surrounded by thickets, the following herbs are especially plentiful:

Alsine media

Cerastium vulgatum

Claytonia parviflora

Equisetum arvense

Equisetum hyemale robustum

Galium aparine

Galium asperrimum
Hydrophyllum capitatum

Mentha canadensis borealis

Mimulus langsdorfii

Saxifraga columbiana

Scutellaria angustifolia

Vagnera sessilifolia

Veronica americana

Among the most typical crevice plants other than those previously enumerated may be mentioned two ferns, Cheilanthes gracillima and Woodsia oregana. The former is especially characteristic of stony outcrops on the buttes and mountains. Heuchera glabella should also be mentioned here.

Other species peculiar to thin soils of rocky ledges are:

Amsinckia intermedia

Arabis holboellii

Crepis gracilis

Gilia aggregata

Phacelia heterophylla

Sisymbrium altissimum

Thalesia uniflora

Valerianella macrocera

The kaleidoscopic character of scab-land vegetation may well be anticipated by a glance at Fig. 39 .

In the thin soil surrounding lichen- or moss-covered basalt may be found herbaceous plants characteristic of the Poa-Polygonum community. Or these may alternate with the shrubby growth of scab-land sage. In the crevices of the rocks may be seen 
dwarfed bunches of Agropyron which is better developed on the talits slope below. This gives way in the deeper soils of the depressions or on protected slopes to various lupines, species of Foa, Balsamorhiza, Hieracium, Gaillardia, and other species. The depressions, if alkaline, may be clothed with dense growths of Distichlis spicata, Spartina gracilis, or Poa brachyglossa and these surrounded by a more or less distinct zone of Elymus condensatus.

The vegetational differences often occur in areas so local as to be seen at a single glance. Alternating with a talus slope of lichen-covered basaltic blocks and only a few feet away, may be seen other slopes which at a little distance appear well clothed with herbaceous vegetation. Such are the interesting situations offered by the rocky soils of canyons and scab-lands.

\section{DESERT SCRUB FORMATION}

In the region under investigation the above formation is represented only in the extreme western part. This formation occupies much of the Columbia Basin, extending eastward to an altitude of about I,200-1,300 feet, and on southerly slopes much higher. Excepting such species as are confined to the moist ground along perennial streams, the great majority of plants are either shrubs or thick-rooted perennial herbs or short-lived annuals. The most conspicuous and ecologically important plant is Artemisia tridentata. Other dominant species are the rabbit brush, Chrysothamnus nauseosus, $C$. viscidiflorus, the scab-land sage, Artemisia rigidia, the antelope brush, locally known as the black sage, Kunsia tridentata, and, in alkaline situations, the greasewood, Sarcobatus vermiculatus.

The life conditions in this region are strikingly more severe than in the region of the high prairies eastward. During the summer of I9I4, Mr. James G. Dickson, my one-time student, made determinations of water content, evaporating power of the air, and soil temperature for a period extending from July 5 to August ${ }_{15}$, at Moxee, Washington, in the heart of this formation. $\mathrm{He}$ found that the average daily evaporation throughout the period from standard atmometers was 51 c.c., while during several days in August it reached 74 c.c. The soil moisture at 6 and 12 
inches respectively, never exceeded 2.8 per cent., while that at a depth of 2 and 3 feet was only slightly higher. Conversely, the soil temperature at 3 inches ranged from $77^{\circ} \mathrm{F}$. to over $112^{\circ} \mathrm{F}$. Even at 12 inches the temperature was usually above $78^{\circ} \mathrm{F}$.

The Artemisia-Atriplex association is represented in this region by the Artemisia consociation.

\section{The Artemisia Consociation}

This consociation, dominated by Artemisia rigida, is a very characteristic type of vegetation over large areas of scab-lands. The scab-lands, as elsewhere indicated, are areas of basalt, probably the flood-plains of former streams, in part, thinly covered with soil. These extend as long tongues over the branching system of river tributaries between the hilly divides. While many of these flats in this region are dominated by communities of Agropyron or Poa-Polygonum, still large areas are characterized by the scab-land sage. This perennial, low, scrubby growth is well adapted to the driest situations on the thin, rocky soil (Fig. I6). Many species typical of the above mentioned communities occur associated with the sage, as might be expected in this zone of transition. Plants characteristic of the desert scrub formation occurring with the sage are Chrysothamnus nauseosus including the variety graveolens, $C$. viscidiflorus, and Tetradymia canescens. It has already been pointed out that some of these play an important rôle in the Agropyron consociation.

In the Snake River Canyon beautiful examples of the abrupt transition from the sage to the Agropyron community are abundant. Rocky, exposed slopes reveal the former, while sheltered slopes only a few meters distant show a well developed Agropyron community.

In passing from the prairie into the scab-land the change in animal population is no less striking than that of the vegetation. In the drier region the Townsend squirrel, Citellus townsendi, replaces the larger Columbian squirrel, C. columbianus, so plenti-
ful eastward. Likewise the presence of the burrowing owl and
rattlesnake is rattlesnake is characteristic. 


\section{Ih: Sarcobatus Consocies}

Communities of the greasewood, Sarcobatus vermiculatus, occur in alkaline soils of the flood plains or depressions in the scaiblands. This scrubby growth, with its pale branches and fleshy leaves, stands out in distinct contrast to surrounding vegetation. The consocies is represented only locally and careful study of it was not made.

\section{THE PACIFIC COAST FOREST FORMATION}

The coniferous woodland occurs in the eastern part of the region and chiefly in Idaho. While the forests in the main grow on the soils produced by the weathering of old crystalline rocks, it is not uncommon in certain parts of the region to find underlying rocks of basalt. Likewise, the sheltered slopes of isolated quartzite buttes may be clothed with trees, or woodland may extend as tongues along the deeper canyons far into the prairie.

There exists a close relation between the development of the physiography of a region and the life history of its forest communities. This is nowhere better shown than in semi-arid climates where a slight change in elevation may so modify the precipitation and other life conditions as to turn the balance slightly or wholly in favor of a tree form of vegetation.

A study of the chemical composition of the soils of basaltic origin as compared with those originating from quartzite, granite, and other crystallic rocks, shows that they are not greatly dissimilar (Table III). I am convinced that it is not the chemical composition of the soils of this region but rather their physical characters that determine the type of vegetation which they support. Of course the controlling factor of the physical composition is, in this region of dry summers, their ability to hold water, provided always that sufficient humus is present to furnish the necessary nitrates. Not only do these forest soils have a higher water holding capacity than those of the basaltic prairies, as has already been shown, but this property increases, due to increased humus content, proportionally as the succession advances toward the climax stage. That coniferous forests will grow upon the basaltic soils is evidenced by their presence over considerable areas in the 
upper Palouse Valley, but the best example is to be found in the woodland growth of that high upfold of basalt in southeastern Washington known as the Blue Mountains. Under the present climatic conditions, the prairies appear to be a subclimax formation.

The higher elevation of these forest-clad foothills and mountains is sufficient to considerably increase the precipitation. The prevailing southwest winds sweeping across the many miles of open prairie and desert of northern Oregon and south central Washington, but gradually ascending, here lose much of their moisture. It is not unusual to observe on a morning in autumn or late spring the surrounding mountains covered with snow while no moisture has fallen upon the lower hills. Sometimes even isolated buttes only 700-1,000 feet higher than the lava plateau are snow clad and stand out in bold relief in contrast to the surrounding country.

A rain gauge of the government pattern placed with Mr. J. B. Kissinger 4 miles northeast of Viola, Idaho, showed, during the years I9I2-I9I4, an annual increase over the rainfall at Pullman during the same period of 3 and 4.5 inches respectively. A similar gauge placed with $\mathrm{Mr}$. Stratton on Cedar Mountain and at an elevation of about 4,000 feet gave 4 inches greater precipitation during the months of July and August, I9I4, than was recorded at the base station. Not infrequently, I have witnessed rather heavy summer showers in the mountains while no rain fell upon the plateau $\mathrm{r}, 500$ feet below.

Not only does the change in altitude affect the amount of precipitation, but it also shortens the growing season. Snow lies on the ground until late in May or-indeed on the more protected slopes even until June. Thus the season of drought is considerably shortened. Likewise, the cool nights lessen the evaporating power of the air.

The forests of the region make up a part of the Pacific Coast forest formation. This formation is represented by the ThujaTsuga association. A single consociation, dominated by Thuja plicata, forms the climax community. Tsuga heterophylla, an 
important member of the climax communities elsewhere, is not represented in the area under consideration.

\section{Symphoricarpos-Opulaster Associes}

A shrub community usually occupies the transition zone between prairie and forest or at least is intimately associated with the earlier stages of development of the latter. I have already mentioned that on the most mesophytic hillsides a more or less well developed scrubby mictium may compete with the grasses. These shrubs are even better developed on the protected slopes of the canyons, where seepage from the rocks may form a very congenial habitat, and where, indeed, they often entirely replace the prairie. Likewise, the sheltered sides of the lower buttes and the more exposed slopes of those of greater elvation may be covered with a rather dense chaparral. The presence of such a shrubby growth indicates increased soil moisture. This at first may be due to slight unevenness in the topography such as a ridge over which snow may be blown and accumulate in sufficient quantity to furnish considerable additional moisture, or, it may be due to biotic factors such as the loosening of the soil by squirrels and other burrowing animals. The water holding capacity of such worked-over areas is considerably increased and results in an immediate dominance of various shrubs, especially roses, Symphoricarpos or Spiraea, which show a much poorer development in the drier, compact soils. The shrubs once present tend to make conditions more mesophytic, a phase which constitutes their most important rôle in succession. Not only do their fallen leaves but also their decaying roots and rhizomes add considerable humus to the soil, while their shade lowers the rate of evaporation from the soil and at the same time prevents the too rapid oxidation of the decaying organic matter. Such enriched soil forms an excellent seed bed for species of xerophytic trees which may invade the sodded prairies only with difficulty. Thus in the normal succession the shrubs may prepare the way for tree growth. The trees in their turn, because of their shade, especially if they are in dense stands, cause the shrubs to disappear.

The Symphoricarpos-Rosa Mictium.-The members of this 
community although present generally throughout the less xerophytic portion of the prairie region seldom come into dominance except on moist sheltered slopes or ravines. In such situations, dense tangles of shrubby growth consisting of the following species may occur:

Rosa mutkana

Rosa gymnocarpa

Symphoricarpos racemosus
Spiraea corymbosa

Vaccinium caespitosum

Prunus demissa

Here, as along sheltered canyon slopes, they may dominate local areas almost to the exclusion of grasses and herbaceous plants. They are frequently accompanied, especially in the latter situations, by dwarfed specimens of Crataegus brevispina, Amelanchier spp., or Populus tremuloides. Where pines occur the preceding trees and shrubs are invariably accompanied by Opulaster pauciflorus, the latter usually becoming the dominant shrub.

The roses are especially conspicuous in May, when their large showy blossoms fill the air with a delicate perfume. Spiraea is always less conspicuous, while Symphoricarpos is much more noticeable in the fall when it is covered with its large white fruits, than throughout its flowering period. Vaccinium caespitosum often covers large areas and while its reddish leaves may add tone to the vernal aspect, later, because of its low stature, it is more or less hidden by other vegetation.

Opulaster Consocies.-As already indicated Opulaster panciflorus is the shrub par excellence of the scrub community. It often covers large areas in almost pure growth especially in the deeper canyons and on the outlying buttes. Its well developed rhizones enable it to invade the grass land which soon gives way because of the dense shade, if the shrubs are well developed. In most situations, the balance between chaparral and prairie is so nicely adjusted that for a long time the shrubs occupy places in swales, ravines, or other irregularities of the surface, while tongues of grass land extend down on the slightly higher elevations (Fig. 23). Among the last herbaceous plants to give way are those of the more mesophytic type such as Geranium, Dry- 
mocultis, and Sidalcea, but not infrequently Opulaster grows in such situations as to replace the more xerophytic grasses and Baisanorhiza.

Chaparral that is so dense as to almost exclude other vegetation is characterized in early spring and before the leaves appear by a layer society of Erythronium grandiflorum. These lilies are often so numerous as to give the appearance of a yellow carpet under the shrubs. In less shaded areas Ranunculus glaberrimus and Olsynium grandiflorum are plentiful. The Opulaster consocies is very conspicuous in May, when its countless white blossoms give a distinct tone to the landscape. Likewise, in late August and September the reddish-tinted drying leaves form a pleasing variety to the monotonous brown of dry vegetation.

While Opulaster frequently characterizes considerable areas alone, it is not infrequently associated with the buckbrush, Ceanothus sanguineus. Indeed, the latter shrub may sometimes become so abundant as to make up half of the mictium. The buckbrush because of its oily seeds, is a very important and fattening food for sheep on the summer range. Numerous other shrubs, such as Holodiscus discolor, Prunus emarginata, and species of Ribes are less important components of this consocies.

Prunus Consocies.-Local areas on the buttes are often characterized by growths of Prunus emarginata. These vary from a rather open growth of stunted shrubs only three feet high to dense copses in which the cherry takes on the stature of a small tree. The characteristic occurrence of this community in dry open places is of considerable ecological significance. I have not infrequently found invading pines extending their territory from sheltered slopes into the drier areas under cover of these shrubs. Frequently the pines may be overtopping the cherries and indeed beginning to replace them, yet a count of annual rings usually shows that the latter were the pioneer woody plants.

Ceanothus Consocies. - On the exposed slopes of Cedar Mountain and adjacent buttes, but seldom found elsewhere in the region, the sticky laurel, Ceanothus velutinus, often dominates. This evergreen, semi-procumbent shrub, while seldom reaching a height of over 4-6 feet, has numerous long branches which spread 
in all directions so that a single plant may cover an area of several square meters. It is frequently so abundant as to form a dense tangle very difficult to penetrate. Other common shrubs associating with it are Ceanothus sanguineus, Pachistima myrsinitis, Salix scouleriana, Holodiscus discolor, and Spiraea corymbbsa. On these steep, gravelly slopes the rôle of the shrubs in catching surface washed materials including coniferous seeds which are frequently buried under the debris, and in shading the soil against excessive evaporation, is an important one in the establishment of the tree stage in succession. Of the forest trees, Pinus ponderosa and Pseudotsuga mucronata are most likely to be found in such situations.

\section{The Pinus-Pseudotsuga Associes}

Although much of the forest in this region has been cut over and still larger areas swept by forest fires, yet large tracts representing all the consocies and mictia of the region are still found in their primeval condition. This is due to the rough topography which makes them inaccessible to the lumberman, while certain areas have been set aside by the federal government as mineral
lands.

The above associes represents types of forest which occupy the drier mountain slopes and are the transition stage from the grass land and shrub to the more mesophytic forest communities. Here are included the yellow pine and the Douglas fir consocies and a pine-fir mictium. The former is the earliest in point of succession and will be considered first.

Pinus Consocies.-Of all the forest trees of the region the yellow pine is best fitted for the pioneer work of foresting prairie, chaparral, or rocky areas. It overcomes xerophytic conditions in part by striking its root-system deeply and spreading it widely, thus laying hold upon large areas of soil. Rooted in rock crevices it may make a height growth of only a fraction of an inch a year and at the age of 40 or 50 years be only a few feet high, yet such examples bear witness to its wonderful powers of resisting
adverse conditions.

The difficulties of pines in invading grass lands should be recog- 
nize 1. Many of the seeds which are overlooked by rodent populations never germinate. Of those that do germinate many dry out hefore they have become well established. Other seeds are prevented from reaching the soil because of the sod. However, under a combination of favorable conditions a few seedlings become fairly established. Surface wash may lodge the seeds against a rock or bush or other obstacle and at the same time cover them with soil. Opportune showers may so favor their growth that they become well established. Having gained a permanent foothold they may reach maturity. These pioneer trees establish a more congenial habitat for their offspring. The fallen needles and branches catch more surface water and debris, and decaying, aid the grasses in increasing the humus content and consequent water holding capacity of the soil. Likewise, shading prevents the rapid oxidation of humus and at the same time lowers the evaporating power of the air. It is not unusual to find parent trees in prairie openings establishing about themselves just such areas of ecesis. In this way forests may replace prairies.

The invasion of pines into chaparral is accomplished with less difficulty, especially if the latter is of not too dense a growth. The shrubs not only modify the edaphic condition in a manner already indicated but also the aërial plant parts are greatly sheltered, especially from drying winds. I have noted scores of situations where shrubs were advancing up butte slopes into the prairie, while numerous pine trees of all sizes and ages had established themselves in the chaparral. However, the chaparral is often so dense as to prevent the establishment of the pines. This happens when the light under the shrubs falls to an intensity of 0.15. But usually, even in such situations, there are open places in which forest growth may occur provided tree seeds are present.

It is probable in this semi-arid region that during the more favorable years of a climatic cycle the forest trees are able to gain a foothold in situations where growth conditions would be too severe ordinarily. An investigation along this line would probably throw considerable light upon the puzzling problem of an isolated stretch of yellow pine in the canyon of Union Flat 
Creek, at a distance of 12 miles from any contiguous body of timber. However, this is a phase of the problem which I found little time to study.

The yellow pine consocies forms the transition zone from prairie or shrub to other types of woodland. In the mountains it occupies exposed south or southwest slopes or only the tops of these if the lower slopes are sheltered. Not infrequently it is accompanied by Douglas fir.

On the exposed buttes only scattered trees may occur among the shrubs on north slopes. In other cases well developed forests may be found. On higher buttes, the rocky tops, ravines, and sheltered bases may be clothed with a pine forest, while large stumps, or isolated pines towering above the Douglas fir and tamarack now in possession of the moist, sheltered slopes, tell the story of a former occupation by a pine forest. Thus all stages of development are strikingly shown on these butte ramparts of the forest frontiers. Often on wind-swept ridges a sheltering spur permits the growth of pines, while a slight descent from a pine-clad ridge may reveal an entire change in tree dominants, the Douglas fir and tamarack replacing the pine.

As already indicated, the pines have worked their way down the Palouse River and along Rock Lake. In the shallow canyons they are practically confined to the sheltered canyon sides. Douglas fir and Larix accompany them in the deeper canyons of the Palouse River, but I have found only the former with the pine about Rock Lake. Opulaster pauciflorus invariably accompanies these forest outposts and its distribution is undoubtedly due to chipmunks and squirrels, which are likewise ever present in pine woods. Numerous plants, which otherwise are found only in the mountains also occur in these pine-clad canyons. Among others Aconitum columbianum, Actaea spicata arguta, Thermopsis montana, and Veratrum viride may be mentioned. In fact, the study of plant populations upon wooded buttes isolated by a distance of from only a few to several miles from the forests proper is fascinating and instructive, but one into which we can not well enter here.

The xerophytic conditions under which the pines grow about 
Rock Lake are remarkable. Upon the thin soils which seem able to support only a Poa-Polygonum community and where even the bunci-grass seems dwarfed, pine seedlings establish themselves, rooting in the crevices, and eke out an existence for years. On the rocks in early August, everything is dry and burned. Even Amelanchier, cherry, and Spiraea become defoliated, still the pines hold on until relieved by the advent of autumn showers. Their stunted condition stands in marked contrast to their well developed companions in the more protected places with deeper soil.

In the open park-like growth of the yellow pine in the mountains it is not unusual to find fine clean-boled trees $2.5-3$ feet in diameter towering above one or two younger generations. In other situations the forest is less open, and is then usually mixed with Douglas fir. In such situations, as one would expect in a transition region from prairie to forest, the ground cover is composed more largely of prairie than of forest forms. The following lists indicate the more important shrubs and herbs of open pine woods :

\section{Amelanchier florida \\ Arctostaphylos uva-ursi \\ Ceanothus sanguineus \\ Holodiscus discolor \\ Opulaster pauciflorus \\ Pachistima myrsinites \\ Prunus emarginata}

\author{
Rosa gymnocarpa \\ Rosa nutkana \\ Salix scouleriana \\ Spiraea corymbosa \\ Symphoricarpos racemosus \\ Vaccinium macrophyllum
}

Achillea millefolium lanulosa Agropyron spicatum (including var. inerme)

Anemone piperi Antennaria dimorpha Antennaria luzuloides Antennaria racemosa Apocynum pumilum Arnica cordifolia
Aster conspicuus Astragalus mortoni Bromus marginatus Calamagrostis rubescens Campanula rotundifolia Deschampsia elongata Deschampsia calycina Drymocallis convallaria Epilobium angustifolium 
Erythronium grandiflorum

Fragaria bracteata

Fragaria platypetala

Frasera fastigiata

Galium spp.

Geranium viscosissimum

Helianthella douglasii

Hieracium albiflorum

Juncoides campestre
Leptotaenia multifida

Lupinus laxiflorus

Lupinus ornatus

Moehringia macrophylla

Pentstemon pinetorum

Potentilla blaschkeana

Pteridium aquilinum pubescens

Sedum douglasii

As the pine forest becomes more closed the shrubs tend to disappear, and usually considerable Douglas fir and tamarack are to be found. The transition from pine to the pine-Douglas mictium or Douglas-Larix mictium takes place in this manner. Not only has the closed pine forest established more congenial conditions for tree seedlings, but it has made its own reproduction difficult if not impossible by a cutting down of the light intensity. In order for yellow pine to thrive, the sun must strike the seedling the greater part of the day. Small openings in forests made by the removal of a few trees by windfall or natural death do not furnish sufficient light. However, the slightly more tolerant Douglas fir and tamarack can not only grow here, but actually shade out competing pine species. Thus the physiognomy of the forest may gradually change from pine to Douglas fir or to Douglas fir and tamarack with all intermediate combinations in mictium. Consequently, mixed forests of pine and Douglas fir into which Larix is invading are common. The shrubby and herbaceous flora, of course, is intermediate between that already given and that of the more mesophytic Pseudotsuga-Larix mictium to be described.

The Pseudotsuga Consocies.-Well developed communities of Douglas fir occupy the upper exposed slopes in the mountains. Frequently the stand is 90 per cent. or more pure Douglas fir but lower down the slopes it is almost invariably mixed with Larix and white fir, to which, along the ravines, it may almost entirely give way. Likewise, in more open places it is accompanied by yellow pine. 
Where the growth is rather pure, the trees, a foot or more in diameter, are pruned high and the dense shade permits of a very sparse ground cover. In such situations, the light intensity may fall to 0.01 or even lower. Except for a few specimens of Coptis occidentale, Anemone piperi, Moehringia macrophylla, Thalictrum occidentalis, or Vaccinium macrophyllum the ground may be quite bare. Douglas fir grows only poorly at light values of 0.025 . Such forests may completely surround bare rock-topped mountain peaks, but more often give way to shrubs or small areas of grass land. Except in such situations I have never seen Douglas fir invading prairie.

Douglas fir is far more common in mixture with Larix and white fir than in forests of which it is the dominant. The percentage of Douglas fir is usually determined by the slope and exposure and consequent soil moisture. While Larix and white fir do not grow in as dry soil as Douglas fir, the latter is less dominant in moister situations because of its greater light requirements. Larix is slightly, and white fir much more tolerant than Douglas fir.

\section{The Larix-Abies Associes}

This associes makes up by far the most important forests of the region. Great stretches of moist mountain slopes are covered with forests of which either Larix or Abies are dominant or more often the two form a mictium. The Larix consocies, dominated by Larix occidentalis, occupies the higher slopes of lower water content intergrading from the Douglas fir above to the more mesophytic white fir-cedar mixture of the moister slopes, ravines, and valleys.

It has already been pointed out that the larch is only slightly less xerophytic than the Douglas fir. Its place in the succession is intermediate between the Douglas fir and the white fir. Its ability to withstand the wind-storms that uproot white pine and white fir is an index of a well developed root system, and this probably accounts for its ability to grow in soils where the surface layers are quite dry.

The absence of Larix seedlings in a mature forest shows that 
the young trees can not endure shade. However, openings of greater or lesser extent constantly occur in primeval forests due to the dropping out of old trees, to windfalls or to fires. Since Larix seedlings can do well in openings where the sunlight enters during the middle of the day, the chances for reproduction are always present. The tamarack, because of its thick bark, is distinctly a fire-resistant tree, often remaining unscathed where white pine and white fir are killed. Hence, large tracts of burned areas, where the tamarack was abundant, now appear to form nearly pure Larix communities. However, an examination of the new tree populations, together with comparisons with unburned contiguous areas, reveals the true mixed nature of the original forest. In such places the white fir is especially prominent.

Abies grandis is not only more tolerant of shade but is also more mesophytic than the larch. I have not infrequently found fir seedlings in shade so dense as to exclude all other trees except the cedar. White fir seedlings can grow in light as low as 0.02 to 0.015 . Under such conditions, however, growth is poor. While it can develop in open places in rather dry soil, it is more exacting in soil moisture requirements than either Douglas fir or Larix.

The position of Abies in the normal succession is beautifully illustrated on sheltered slopes of outlying mountain spurs and buttes. Passing from the dry open pine forest one can find all stages from pine-Douglas fir mixture dominated first by the pine, to a pine-fir-tamarack mictium where the tall, spindly, bushytopped pines, many of which are dead, tell the story of the lost struggle for light. Areas of higher water content on the same slope may show Pseudotsuga-Larix mixtures with the fir losing its dominance and Abies grandis appearing. The next stage is that of a Larix-Abies mictium with the coming in of cedar. Characteristic plants of these drier Larix-Abies forests are given in the following lists :

Ceanothus sanguineus

Holodiscus discolor

Opulaster pauciflorus

Pachistima myrsinites
Ribes viscosissimum

Rosa gymnocarpa

Rubus parviflorus

Salix scouleriana 
Vaccminm macrophyllum

Anemone piperi

Arnica cordifolia

Calamagrostis rubescens

Chimaphila umbellata

Coptis occidentalis

Cytherea bulbosa

Fragaria bracteata
Fragaria platypetala

Linnaea borealis longiflora

Micromeria chamissonis

Pyrola picta

Thalictrum occidentale

Trillium ovatum

Vagnera amplexicaulis

While Opulaster pauciflorus is the most abundant undershrub in the pine consocies, in the Larix-Abies community it remains only as a relict. It is not unusual to find areas of dead ninebark under a growth of tamarack or white fir.

Ribes viscosissimum while occurring sparingly in the earlier stages of succession is frequent in these dry fir-tamarack forests but is a more typical undershrub of the more mesophytic firtamarack community. In the cedar consociation it gives way to the more mesophytic Ribes lacustre.

Likewise, Arstostaphylos uva-ursi, common in pine woods, is seldom found here. Linnaea borealis longiflora replaces it, covering large areas with a carpet of trailing stems. The twin-flower is less abundant in the deep shade of well developed fir-tamarack forests and drops out completely in the cedars.

In well developed forests the white fir not infrequently reaches a diameter of 2.5-3.5 feet, while neighboring tamarack trees reach diameters of similar proportions. Likewise, Douglas fir frequently attains a diameter of 3 feet, a relatively small tree compared with the dimensions it reaches in the humid Washington region west of the Cascades. Under the closed canopy of such a forest, shrubs are almost excluded and herbaceous plants are not abundant. The light values may drop to an intensity of only 0.01 or even 0.007 .

In more open places a poorly developed shrubby layer may overtop an upper layer of herbaceous plants, which like the former is not well developed. Indeed, both may be absent and then a scattered growth of low-growing herbs with a few fungi and mosses may partially cover the ground. The sparse growth of 
fungi as well as such saprophytes as Corallorhiza spp. and Pterospora andromedea appears meager indeed to one accustomed to the rich fungal flora of an eastern deciduou's forest.

The following lists indicate the shrubs, herbs, and some fungi commonly found in well developed mesophytic forests:

Chimaphila umbellata

Lonicera utahensis

Menziesia ferruginea

Pachistima myrsinites

Pyrus sitchensis

Ribes viscosissimum

Actaea spicata arguta

Adenocaulon bicolor

Anemone piperi

Arnica cordifolia

Asarum caudatum

Clintonia uniflora

Coptis occidentalis

Disporum majus

Fragaria spp.

Galium spp.

Boletus sp.

Clavaria spp.

Coprinus comatus

Gyromitra esculenta
Ribes lacustre

Rosa pisocarpa

Rubus parviflorus

Sambucus melanocarpa

Vaccinium macrophyllum

Linnaea borealis longiflora

Mitella stauropetala

Osmorhiza divaricata

Pyrola spp.

Streptopus majus

Thalictrum occidentale

Tiarella unifoliata

Trillium ovatum

Vagnera amplexicaulis

Morchella bispora

Morchella spp.

Peziza spp.

Sarcosoma globosum

These changes in the shrubby and herbaceous populations from the less mesophytic to the more mesophytic members as the succession advances are no less characteristic than the changes in the lichen flora which abounds on the trees. While in open pine woodland the trees are often covered with the yellowish and grayish patches of Letharia vulpina and Parmelia physodes, in the early stages of the Douglas fir-tamarack community these lichens give way especially to species of Alectoria. Of these the long pendant thallus of $A$. fremonti is especially characteristic, while 
A. oregana is less abundant. As conditions become more mesophytic in the Larix-Abies community, Usnea dasypoga begins to predominate, while in the climax cedar consociation the trees are often beautifully draped with the long yellow strands of this species. Under such conditions species of Alectoria are not frequent.

Other trees which are more or less important components of these forests are the white pine, Pinus monticola, lodgepole pine, Pinus murrayana, yew, Taxus brevifolia, and Engelmann spruce, Picea engelmanni.

The white pine, although more abundant and of greater value on the bottom lands of streams in northern Idaho than anywhere throughout its range, is not an important tree in the area under consideration. It occurs only sparingly throughout and where it is best developed on the moister slopes, seldom makes up more than 5 per cent. of the forest and reaches this abundance in only local areas. It appears to require a moister soil than white fir, but its seedlings can stand considerable shading. Perhaps the dryness of the climate combined with the ravages of forest fires which may kill it and leave larch and red fir uninjured, combined to make it an unsuccessful tree in this region.

The lodgepole pine, Pinus murrayana, occurs very sparingly throughout the western forest frontier of the region. Eastward and northward, especially in cut-over and burned-over regions, it assumes considerable importance, occurring in mixture throughout all types of forest, and frequently forming dense even stands over considerable areas. Unlike the yellow pine it seldom plays the rôle of pioneering in grass land and since it is distinctly a "fire tree" of a weedy nature, it had best be considered in another place.

Taxus brevifolia is very rare in this region, occurring only occasionally along ravines and then taking on only a scrubby form. Its rôle in the forests of the region is insignificant.

Engelmann spruce, so characteristic of high mountain slopes elsewhere, while never found in great abundance, is rather a frequent forest tree at the highest altitudes, especially in wet ravines and about the edges of alder swamps. It does best in soils where 
the deeper strata are very moist. Outside of meso-hydrophytic situations it does not flourish in the region and even here it does not reach the usual size of the species. It sometimes forms a very broken and fragmentary zone between the alder-willow community and the climax cedar forest. Its ability to tolerate shade to a greater degree than Douglas fir or tamarack probably accounts for the presence of its seedlings in drier situations, for I have shown that conditions under typical stands of white fir and tamarack are, as regards the seedling stage, fairly mesophytic. Likewise, its power to germinate in the open, providing there is sufficient soil moisture, accounts for its presence, often in dense stands, in situations where drifts of melting snow keep the soil well moistened in otherwise apparently rather dry, rocky situations. Like other shade-enduring species, it makes a more rapid growth in these situations than in the shade.

\section{The Thuja Consociation}

The climax forest community of the region and the one in the xerosere with the lowest light intensity, greatest soil and air humidity as well as lowest temperature, is that dominated by the cedar, Thuja plicata. The best protected and most mesophytic mountain slopes as well as the well watered ravines are clothed with a growth of this cedar. These often form 90 per cent. or more pure stands and the trees may reach diameters of 3-5 feet. In such well developed forests, the light intensity ranges from 0.015 to 0.005 and even to 0.003 , and except for the seedlings of the cedar the ground may be quite bare. But usually the forest canopy is sufficiently open to permit a growth of a few shadeenduring shrubs and numerous herbs. Of these the following are typical of the consociation:

Ribes lacustre

Rubus parviflorus

Aconitum columbianum

Anemone piperi

Asarum caudatum

Athyrium cyclosorum

Circaea pacifica

Claytonia asarifolia

Clintonia uniflora

Coptis occidentalis 
Galism sp.

Streptopus majus

Tiarella unifoliata

Trillium ovatum
Viola glabella

Viola orbiculata

Vagnera amplexicaulis

The high humus content and consequent great water holding capacity of the soil is probably due in part to the lack of forest fires. For it is easy to see how the more moist areas in the deep ravines would be less subject to burning than the drier slopes with their proportionally greater amount of undershrubs. The forest floor supports the best developed fungus flora of the region. This includes species previously enumerated. However, even here the fungus flora is relatively scanty.

Because of the shade the trees are often pruned high, while the branches are draped with long strands of Usnea. Often at higher altitudes Picea engelmanni accompanies the cedar down the moist ravines but never assumes very great importance.

The greater mesophytism and tolerance of the white fir as contrasted with that of the tamarack and Douglas fir are shown by the presence of the former in the mixed cedar-white fir forest. It is the last of these trees to give way to the cedar, certain communities showing gigantic relict white firs while all of the saplings are those of the cedar. Proceeding up the slope from a cedar community the white firs become dominant as the cedars become smaller and less frequent on the drier soil, then a zone of white fir and tamarack is passed, while further up in this mixture Douglas fir becomes more abundant. Of course, the illustration is rather overdrawn for the accidents of windfalls, and especially fires, may often greatly alter these conditions.

The formation as a living developing entity has reached its maturity in the cedar consociation. Because of the low light intensity the establishment of the seedlings of the other forest trees of the region in the cedar community is impossible. Hence, the adult stage. will go on indefinitely repeating itself generation after generation, unless disturbed by some outside factor as a forest fire or the hand of man.

Having traced the normal development of the forest through the 
xerosere to its climax community, we will next consider briefly a hydrophytic adsere, after which we will take up the secondary succession or subsere.

\section{The Adsere. Almus-Salix Associes}

Distinctly hydrophytic plant communities characterized by Alnus sinuata, Salix scouleriana, and Pyrus sitchensis occupy broad wet ravines and springy places often high up on the mountain sides. The weight of the great banks of snow which drift over the trees and sometimes almost bury them, pushes them into a semi-procumbent position leaning down the slope. The alder, which is usually dominant, reaches a diameter of $2-5$ inches and a vertical height of only 12 or I5 feet, while not infrequently it attains a length greater than twice its height. Likewise, the willow and mountain ash and also the mountain maple, Acer glabrum douglasii, which accompany it in this habitat, are bent down the slopes by the weight of the snow. Because of the late melting of the snow in such situations and the resulting springy nature of the soil, coniferous tree seedlings are excluded. Engelmann spruce, as already indicated, often borders such alder thickets and in turn gives way to the cedar.

In this tangle of semi-prostrate trees, shrubs are nearly excluded, although Sambucus melanocarpa and Ribes lacustre occur rather infrequently. A dense herbaceous undergrowth which almost completely conceals the ground is made up of the following mesophytic species:

Aconitum columbianum
Actea spicata arguta
Athyrium cyclosorum
Circaea pacifica
Claytonia asarifolia
Clintonia uniflora
Disporum majus

Aconitum columbianum

Actea spicata arguta

Athyrium cyclosorum

Circaea pacifica

Claytonia asarifolia

Disporum majus

\begin{abstract}
Disporum oreganum
Mertensia membranacea

Osmorhiza divaricata

Senecio triangularis

Streptopus amplexifolius

Thalictrum occidentale

Trillium ovatum
\end{abstract}

The preceding plant species together with certain other mesophytic shrubs and herbs and hydrophytic mosses border the moun- 
tain streams, which, indeed, may be fringed with a more or less fragmentary alder community.

\section{SUBSERE. REFORESTATION OF CUT-OVER AREAS AND BURNS}

Since the direction of development is always forward and toward the climax community of a region, the removal of the plant cover, such as a forest, makes possible the repetition of the story of normal succession. This, however, may be considerably modified and the amount of repetition determined by the degree of completeness of the destruction.

In studying the natural reforestation of the region, it will be advantageous to consider first the secondary succession or subsere after cutting, and afterwards the reëstablishment of forests following burns.

Naturally many of the outlying pine-covered areas were early cleared by the settlers and the land used for the cultivation of crops. Where small tracts have been allowed to "go back" after removing the yellow pine and burning the brush, the first years show a rapid growth of shrubs while the intervening spaces are dominated largely by prairie species. Opulaster panciflorus, Spiraea corymbosa and other shrubs, which in the denser stands have been suppressed by the shade, spring rapidly into dominance, while Epilobium angustifolium, Cirsium palousense, Pteridium aquilinum pubescens, and Deschampsia spp. mingle with various prairie species already designated as occurring in yellow pine forests. Among these, yellow pine seedlings grow vigorously and the forest finally reëstablishes itself. Of course, repeated fires kill the pine seedlings, burn off the shrubs, and favor the invasion of prairie plants. Although prairie fires in the Palouse Region were never so severe as those of the Great Plains, it is probable that they played an important rôle in preventing the invasion of conifers into the grass land.

In most of the more accessible canyons of the mountains, lumbering has been carried on and in some places the operation of the lumberman has been followed by ground fires. In practically all cases, except in the lodgepole region eastward, where 
reforestation has occurred, the new forest has usually about the same composition as the old. In these cases, the composition of the previous forest was determined, of course, by a study of the stumps, by checking with the adjacent forest, especially primeval forest areas on similar adjacent slopes. The following case, found by repeated trials to be rather typical, is illustrative.

Belt transects through a second growth forest occupying an area in Thatuna Hills cut over about twenty-five years ago gave the following percentage composition:

Moist North Slope

Yellow pine $\ldots \ldots \ldots .0 .5$ per cent.

Douglas fir ....... 4.0 per cent.

Tamarack ......... 30.0 per cent.

White fir ........ 26.0 per cent.

Cedar ............ 39.5 per cent.
Dry South Slope

Yellow pine ....... 36.0 per cent.

Douglas fir ........ I4.0 per cent.

Tamarack ......... ro.o per cent.

White fir ........ 40.0 per cent.

Superficially such moist slopes appear to be clothed with nearly a pure tamarack forest, due to the more rapid height-growth of this species. In such young forests the cedars are often small, in fact, many are mere seedlings. A count of the annual rings shows that they came in after the other trees had, by their shade, made conditions less xerophytic. Their importance in the general composition of the forest might be overestimated from their high percentage. Farther up the slopes they are scattering, and only near the moist base are they present in great abundance. Likewise, the white fir on the south slope occurs mostly in dense thickets near the base. On the open south slope trees averaged only I per square meter, while on the north slope the average was 3.5 per unit area.

No less characteristic of the two types of forests are the shrubs and herbs of the undergrowth. Opulaster pauciflorus, Ceanothus velutinus, and Salix scouleriana make up the chief shrubby growth on the south slope, often covering many square meters exclusively. On the north slope both Opulaster pauciflorus and Ceanothus velutinus occur but rarely, while Vaccinium macrophyllum is more abundant than Salix scouleriana. Coptis occidentalis, Clintonia uniflora, Thalictrum occidentale, Mitella stauropetala, 
Guilum sp., Asarum caudatum, Anemone piperi, Pyrola bracteata, Cytherea bulbosa, and species of Vagnera, all found here, are typical plants of the moister slopes, and contrast markedly with Catcmagrostis rubescens, Bromus marginatus, Pteridium aquilimum pubescens, Pentstemon pinetorum, Astragalus mortoni, Aster conspicuus, Anaphalis margaritacea occidentalis, Antennaria racemosa, Pedicularis racemosa, and Berberis repens, found on the more open south mountain side.

Cut-over areas in the northeast part of the region, where as a result of fires lodgepole pine is frequently abundant, showed in addition to the usual herbaceous and shrubby growth and tree seedlings of all the common tree species, a frequent dominance of Pinus murrayana. The numerical dominance is a result of its prolific seeding habit, brush fires being sufficient to open many of the cones, while its rapid height-growth makes it stand out prominently when mixed with other species. The developmental history of such areas will be considered under reforestation of burns.

A report of the study of the natural reforestation of burned areas in the mountains of northern Idaho has already been made (6). Although much of the area there included lies outside of the boundaries of the present investigation, still conditions are so similar that a brief statement may be included here.

During the month of August, I9Io, the greater part of northern Idaho and much of eastern Montana was swept by one of the most extensive and destructive forest fires ever experienced in that part of the country. In many heavily wooded canyons the draft was so violent during the fire and the heat so intense as to destroy every vestige of life above ground.

The town of St. Maries, Idaho, lies against the slopes of foothills, which, prior to I9Io, were covered with a more or less mixed forest of coniferous trees comprising the following species: Pseudotsuga mucronata, in practically all situations; Pinus ponderosa, abundant on south slopes and in exposed and rocky situations; Larix occidentalis associated with Abies grandis and Pseudotsuga; Pinus monticola and Thuja plicata accompanied by indi- 
viduals of Pseudotsuga and Abies, confined generally to the canyons and rich levels at the bases of north slopes.

These mountain slopes were overrun by fire on August $2 \mathrm{i}$ and 22, 1910. As they seemed to represent fairly the average forest conditions for northern Idaho, it was decided that here would be a most satisfactory place to carry on a study of the problem of natural reforestation.

Among the first pioneers to reclaim the unshaded and charred soil were Funaria hygrometrica and Marchantia polymorpha. Cirsium palousense, Erigeron acris, and Epilobium angustifolium were the chief herbs, whose wind-blown fruits afforded them an early entrance. Likewise, the numerous seedlings of Salix scouleriana may be accounted for in the same manner, while numerous others sprang up from the underground parts of the older willows characteristic of more open areas. The presence of Opulaster pauciflorus, Arnica cordifolia, and Erythronium grandiflorum may likewise be accounted for by the fact that the fire left unharmed the rootstocks of the shrub and of Arnica and the corms of the lily.

In the spring of IgII and the second year after the fire, Epilobium angustifolium was predominant everywhere. The individuals varied from mere seedlings to plants $12-18$ inches in height, often as many as 30 to 50 individuals occurring in a single square meter. Thousands of the smallest were succumbing to an epidemic of Aecidium. Next in importance to the fireweed was the thistle, Circium palousense, which with Antennaria luzuloides and the species enumerated as occurring the preceding year, formed a considerable herbaceous carpet over the burned area. Every inch of the ground otherwise unoccupied seemed covered with Funaria hygrometrica. The following shrubs, Opulaster pauciflorus, Rosa gymnocarpa, and Rubus parviflorus, which were more or less abundant, had, like several of the herbs in the following list, been able to survive the fire by means of underground propagative parts. The bulbs of $Z$ ygademus venenosus and Fritillaria lanceolata, and the corms of Erythronium grandiflorum, all of which were present in considerable abundance, were found at depths of 5-7 inches below the surface of the soil. Other plants 
present in greater or lesser abundance were Potentilla sp., Mitella stauropetala (abundant), Leptotaenia multifida, Disporum majus, Moehringia macrophylla, Coptis occidentalis, Viola spp., two species of Lathyrus, and Vicia sp.

It is of interest here to note that in spite of the terrific heat which must have prevailed over those mountain slopes, except where the undergrowth was dense, a considerable depth of humus remained intact. Where this was wholly consumed and the soil had been washed bare by rains there was a fairly complete turf of Funaria and Marchantia along with certain herbaceous plants already given. The effects of this forest fire were more profound in certain parts of the forest than in others, depending somewhat upon the topography of the devastated region. In the "draws" or small lateral canyons where growth conditions were such as to produce the most excellent stand of white pine, Douglas fir, white fir, and cedar, the fire was most destructive, leaving no trees alive. Whereas, on lateral or secondary ridges it was frequently observed that from 25 to 75 per cent. of these species, including yellow pine, survived the heat. These constituted the seed trees so valuable in the reforestation now going forward.

A diligent search was made for any seedlings of the conebearing trees characteristic of the region under observation, and a few were found. A limited number of these (all were Larix occidentalis) were from seed germinated in $\mathrm{I} 9 \mathrm{II}$, but the majority were but a few weeks old at the time of observation. They were indeed scarce-not more than $60-80$ per acre on north and east slopes and none at all on south and southeast or southwest exposures. In two instances it was observed that as many as $I_{5}-20$ seedlings were growing in one spot as though a cone had become planted and all its viable seeds had germinated. The area investigated seemed to show no signs of any other conifer, which fact corroborates observations of a similar nature made in certain denuded sections of Thatuna Hills. However, by the fall of the same year, many seedlings of Thija, Larix, Pseudotsuga, and a few of Abies had sprung into existence.

It is probable that some of these seeds were furnished by scattered surviving parent trees in the vicinity, although it is 
equally certain that others buried in the moister duff escaped burning. Hoffman (7) has shown that seeds of Thrija plicata may remain dormant in the soil for two years, while those of Pimus monticola and Pseudotsuga mucronata may be buried in the duff for six years and still remain viable.

The distribution of the seedlings was very irreguiar. In some areas of a square meter or more none could be found, while in other more favored spots the seedlings would average as many as 8 per square meter. The ground occupied by these seedlings was well covered with a mulch of the dead leaves and stems of such herbaceous plants as have already been described for the region.

On the denuded south slopes where the original forest growth consisted of an abundant stand of Pinus ponderosa with scattered individuals of Pseudotsuga mucronata, notwithstanding the presence of a growth of Symphoricarpos, Pteridium, Epilobium, Cirsium, Achillea, and other plants in considerable abundance and so intermingled as to form a semi-shaded protected area, no coniferous seedlings were present. Their absence was no doubt due to insufficient soil moisture and excessive evaporation.

These south mountain sides and their ravines and canyons will in the course of time be reclaimed by a new growth of yellow pine and Douglas fir unless ground fires occur and natural growth conditions are obliterated.

Reforestation studies in areas swept by fires of all degrees of severity were made, especially in Thatuna Hills. In some cases only very local areas were concerned, while in others the fires covered considerable territory (Fig. 43). In practically all cases sufficient seed trees were either left standing in the burned area or on unburned ridges in close proximity to furnish the seed for reforestation.

About twenty-nine years ago, many square miles of these hills were overrun by a fire which destroyed more or less completely much of the virgin timber, leaving here and there a few living trees representing the different species to serve as seed trees in subsequent years. These burns covered chiefly the north and northeast slopes of the mountains. In these mixed forests of 
White fir, tamarack, Douglas fir, and cedar, the thick-barked tamarack suffered least, and often only the trees of this species less than 6-8 inches in diameter were killed. This gave rise to whit are apparently nearly pure forests of tamarack; but in most cases sufficient seed trees of the other species were left to insure re-seeding, and at present a new generation of white fir and tamarack are especially prominent.

Notwithstanding the now open nature of the forest, the ground being covered with the blackened and charred remains of fallen white firs and cedars, many of the smaller tamaracks, though dead, are still standing. The larger ones, often fire scarred, but living, are not usually more than $12-14$ inches in diameter. They reach a height of $85-100$ feet, and, like the fir, reveal by their high pruning a former forest with a closed canopy.

On the upper and middle slopes the ground is more or less completely covered by a thin layer of raw humus, consisting mostly of the leaves of the tamarack. Numerous quadrats in various areas revealed a predominance of the seedlings of the white fir, often $20-25$ per square meter, while Douglas fir and tamarack were less abundant. In many places the mineral soil was destitute of vegetation, while only a sparse growth represented by Hieracium albiflorum, Clintonia unifora, Adenocaulon bicolor, Galium sp., Chimaphila umbellata, Micromeria chamissonis, Pyrola picta, and a few other scattered species occurred elsewhere.

The severe conditions under which the tree seedlings were growing were shown by the fact that even the oldest, which came in at least three or four years after the fire, did not exceed a height of $\mathrm{I}_{5}-\mathrm{I} 8$ inches.

Judging from adjoining and unburned forests of a similar composition it appears that the remaining tamaracks by a spreading of their crowns had considerably increased the shade, the light value often falling to 0.2 , and thus offering considerable protection to the tree seedlings.

Farther down on similar slopes, where the fire left fewer trees standing, both because fewer tamarack trees were present and because the fire was more severe, quite a different stage in reproduction is to be seen. Here, because of more moisture and the: 
open Iight, average major quadrats revealed as many as 200 tree secillings. Of these nearly four-fifths were white fir and tamarack, about equally distributed, while the rest were Douglas fir, white and yeliow pine. Many of these were I9-20 years old, with a height-growth of 6-13 feet, the tamarack as usual in the lead. In the moist ravines young cedars were abundant. The early history of this forest was probably the same as that of the St. Maries region already described.

In heavy burns in other parts of the region where big cedar, spruce, white fir, and tamarack timber have been completely destroyed, various species of shrubs, especially Vaccinium macrophyllum, Menziesia ferruginea, Salix scouleriana, and thickets of Alnus, Rubus parviflorus, Ribes lacustre, Rubus macropetalas, and maple had sprung up and almost completely covered with their dense growth the fire blackened tangle of fallen trees. However, they form a good protection for the tolerant cedar and spruce, and while they may shade out other seedlings for a time, still there are always openings, and especially in drier soil where the less tolerant but also the less exacting fir and larch can get a foothold.

Without further details the general story of reforestation of burns in the region is as folows: Soon after the fire the ground is more or less completely covered with cryptogamic vegetation of which Funaria hygrometrica and Marchantia polymorpha are dominant. Soon plants with wind-blown fruits appear. Of these the following are most important:

Epilobium spicatum

Salix scouleriana

Cirsium palousense

Erigeron acris

Certain grasses, as Bromus marginatus, and fire grass, Agrostis

Hieracium albiflorus

Antennaria luzuloides

Anaphalis margaritaceae occi-

dentalis

hyemalis, may predominate for a time but later give way to other hyemalis, may predominate for a time but later give
herbaceous growths, especially of Epilobium (Fig. 44). After
one or more years, varying with the severity of the burn and degree of exposure, tree seedlings begin to become established. 
These may be shaded by too dense thickets of various shrubs, which may spring up from underground parts, and largely replace the herbaceous vegetation. But usually the shrubs form a protection against wind and excessive evaporation. The trees in turn suppress the shrubs and the mature forest, usually similar to the one preceding, is replaced.

Studies of reforestation in burns of varying severity show more or less incompletely the several stages of the subsere. However, continued investigation in these and in completely burned areas indicates the following seral stages, some of which may be telescoped or even lacking in any one particular burned area.

\section{Salix-Vaccinium Associes \\ Vaccinium consocies \\ Rubus consocies \\ Salix consocies \\ Epilobium-Cirsium AssocIES \\ Cirsium consocies \\ Epilobium consocies \\ Agrostis-Bromus Associes \\ Bromus consocies \\ Agrostis consocies \\ Funaria-Marchantia ASSOCIES \\ Marchantia consocies \\ Funaria consocies}

There remains only to be considered briefly reproduction in the burns in the northeastern part of the area and especially along the Palouse River where the lodgepole pine plays a significant rôle. The wide range of the lodgepole habitat from very moist to very dry soil, its rapid growth and early reproduction as well as its inability to withstand fires or to endure shade are too well known to necessitate discussion here.

The forests of this part of the region, where lumbering operations have been going on for a long time and burns of all ages occur, are mixed throughout with lodgepole pine, the amount of which may vary from a few towering relict trees to nearly pure
stands. 
In case of a limited but severe burn in the midst of a mixed forest, provided a few lodgepole seed-trees are present, the following generation is usually predominated by the lodgepole pine. Provided the various tree seedlings have an equal start, the lodgepole, because of its more rapid height-growth, gains an ascendency over its neighbors. Likewise, by its habit of early reproduction (I have frequently found trees only seven years old bearing cones) it furnishes seeds for any unoccupied areas or for the entire area if seeds of other trees for any reason fail to be present. I have seen a few such areas dominated by lodgepole pine but comparatively they are not abundant.

But because of its early maturity and its inability to reproduce in its own shade, in spite of the advantage gained in the middleaged forest, the lodgepole is the first tree to drop out of the mature forest. Unless aided by another fire before its competitors reproduce, it assumes a less and less important rôle. Indeed, in most of the forests it occurs only as scattered individuals, although, as previously stated, in areas cut and burned-over thirty to fifty years ago the lodgepole pine is not infrequently an important tree.

\section{THE HYDROSERE}

We shall now take up the development of the hydrosere. An outline of the vegetational units of this sere together with their relation to the xerosere may be found on page 19. Because of the peculiar topography of the region, combined with the arid climate, hydrophytic and meso-hydrophytic communities are not widely represented. However, along the streams and in small ponds and lakes, the latter occurring especially in the northwestern part of the region, the following communities are found. The three well marked associes of the water sere showing striking changes of habitat and life form as well as definite floristic differences, are those dominated by submerged, floating, and swamp plants respectively, in their successional sequence. The last stage is succeeded by a wet meadow community which is usually followed by a consociation of the Agropyron-Festuca association but may be replaced by the flood-plain forest associes. 


\section{The Chara-Potamogeton Associes}

In shallow ponds and small clear streams it is not an unusual sight to find the water rather completely filled with various submerged plants, of which sometimes Chara and sometimes Potamogcton pectinatus or $P$. californicus are dominant. Perhaps there occurs more often a mictium of the dominants of the two consocies respectively.

In addition to Vaucheria, Stigeoclonium, and other algae, which are frequently very abundant in such situations, Najas flexilis, Zannichellia palustris, and Batrachium aquatile, also help make up the tangle of submerged plant life.

The water crowfoot shows great plasticity in its habitat requirements, and as the ponds become shallower it is not unusual to find it dominating considerable areas of muddy banks. The aerial leaves with their well developed blades appear in striking contrast to the filiform submerged ones.

The róle of these submerged plants in the preparation of a suitable substratum for later stages in succession is frequently very marked. As a result of the dense aggregation of the individuals of the constituent species of this community, bodies of water often exhibit a pronounced accumulation of debris consisting for the most part of the remains of former generations of aquatic plants and animals but mixed with fine soil particles brought in by the action of wind and water, the whole being effectively held in position by the expanding tangle of living plants. The accumulation of humus decreases the total amount of water in the substratum and the habitat gradually approaches a little nearer the mesophytic. As the bottom of the pond is slowly raised by the accumulating debris, the substratum becomes relatively more compact.

A continuation of these processes reacts unfavorably upon the submerged plants and they thus prepare the way for their own elimination. Not only is the reaction of initial stages of succession unfavorable to the pioneer plant community but it also actually favors invaders. Plants with slender stems and floating leaves, such as Potamogeton and pond lilies, for a time take possession 
of the shallowed water, while through the agency of further humus accumulation, a suitable foothold is eventivally afforded for the development of cattails, sedges, rushes, and other members of the marsh community.

About the margins of shallow ponds and streams and often growing in shallow water are to be found Mimulus langsdorfii, Veronica spp., Radicula spp., Ranunculus alismaefolius, or Steironema ciliatum. If the ponds are larger, the shallower water near the margins is often dominated by plants of the following community:

\section{The Nymphaea-Potamogeton Associes}

Typically this associes is composed of plants rooted in the mud below but with a part or all of the leaves floating on the water surface. Their general position in the sequence of succession is following that of the submerged forms, whose reaction upon the habitat, as previously pointed out, is to shallow the water and thus make it less fit for themselves and more fit for the anchored floating forms.

The Marsilea community is well represented in certain small ponds but is most conspicuous in the rock pockets in the beds of streams during the dry season. The ability of Marsilea vestita to float on the surface of water of varying depth or to live rooted in the mud or even in rather dry soil fits it to occupy just such a changing habitat. However, it is far less important than members of the following consocies.

The Potamogeton consocies consists of various species of Potamogeton of which P. americamus often is dominant (Fig. 29). Frequently associated with it are the submerged $P$. pectinatus and $P$. californicus. In late summer ponds containing the latter species are sometimes margined for considerable distances from the shore with the broadly expanded leaves and the dense spikes of $P$. americanus. Associated with it are Polygonum amphibium and the duckweeds, Lemna minor, L. trisulca, and locally, Spirodela polyrhiza.

Other ponds and especially lagoons along the upper Palouse River are characterized by an abundance of Nymphaea poly- 
sefala, whose broad leaves and pretty yellow flowers almost comDletely cover the water for many square meters (Fig. 30).

Additional floating-leaf aquatics are occasionally seen in mixture with the lily. The commonest of these are species of Potamogeton and Alisma plantago-aquatica.

Where the current is swift enough during a part of the year to keep the bottom relatively free from debris, the lily community may continue for years. But by continued humus accumulation and elevation of the bottom, the habitat becomes invaded more and more completely by plants of the marsh community and finally the lilies disappear entirely.

\section{The Scirpus-Typha Associes}

Like the preceding, the associes characterized by Scirpus and Typha is found covering only very limited areas considering the region as a whole. I have rarely seen the two dominants growing together, and, in fact, Typha is not abundant. However, observations on Typha in its limited habitat together with a study of its relict associates in shallow water show rather clearly its place in the succession.

The Scirpus consocies is more widely represented. The dominant species are the western tule, Scirpus occidentalis, and Scirpus microcarpus. While often growing in rather deep water about lake margins where they are sometimes associated with relict Nymphaea and Potamogeton, they likewise occupy boggy places, which in late summer may become mere mud flats (Fig. 31). Among the tall stems of the bulrushes is often revealed a distinct layer of Alisma plantago-aquatica, Sagittaria arifolia, and Mentha canadensis borealis, while among these various species of creeping buttercups may be seen.

Sometimes, as at Tule Lake, a slightly higher and consequently drier habitat gives a fine zonation of Eleocharis palustris and other members of the Eleocharis-Carex community. The presence of the latter among the tule in the drier portions of its area indicates the next stage of development. 


\section{The Eleocharis-Carex Associes}

This plant community covers areas along the fiood plains of smaller streams which are wet during the rainy season but often quite dry during the late summer months. Likewise, about the borders of lakes and springs it occupies situations of lower water content than those characterized by Scirpus or Typha.

The Eleocharis consocies is dominated by E. palustris. It sometimes covers considerable areas with a pure growth (Fig. 3I). Its rhizomes form extensive mats which abound at the edge of ponds as well as in the shallow water. Associated with it is $E$. acicularis. It likewise has well developed and extensive rootstocks, while those of E. acicularis bella are very short so that the mats assume the form of dense round tufts. Because of its lesser height-growth the latter species is easily distinguishable from the former.

Frequently occurring in mixture with Eleocharis are various sedges and rushes of the following community.

The Carex-Juncus Mictium. - I have never seen in this region any considerable area dominated by one species of Carex or Juncus. However, a study of the fragmentary areas characterized by this community reveals the dominance of Carex nebraskensis and Juncus balticus locally. More often the following species occur in a puzzling mictium:

Carex lanuginosa

Carex monile pacifica

Carex nebraskensis

Carex pachystachya

Juncus balticus
Juncus bufonius

Juncus ensifolius

Juncus suksdorfii

Juncus tenuis

In addition to relicts of the preceding communities, associated with the above species are to be found numerous other plants of which the most important are Beckmannia erucaeformis, Radicula curvisiliqua, Alopecurus californicus, Epilobium adenocaulon, Carex utriculata, and Mentha canadensis borealis. The lastnamed plant is very important ecologically. It has well developed and extensive rhizomes. It not only thrives in very wet 
situations but likewise occurs abundantly on the thin soil of the stony bottoms of intermittent streams.

\section{The Wet Meadow Associes}

The wet meadows occupy a zone lying intermediate in succession between the Eleocharis-Carex associes on the one hand and the more mesophytic type of prairie on the other. As would be anticipated, it shows all stages of the disappearance of relict members of the Eleocharis-Carex community which it frequently borders, as well as the invasion of the more mesophytic prairie species.

However, the community as a whole is well defined and is especially characterized by numerous socies. These wet meadows often occupy considerable areas, especially near the mountains, and under cultivation furnish an excellent yield of timothy.

Omitting relicts of earlier communities, and many species found typically on moist hillsides, the following list gives the principal wet meadow species:

Species Forming Distinct Socies.-

Deschampsia caespitosa

Hookera hyacinthina

Heracleum lanatum

Iris missouriensis

Polygonum bistortoides
Calochortus nitidus

Carex aperta

Castilleja miniata

Cicuta occidentalis

Cogswellia triternata

Delphinium simplex

Epilobium adenocaulon

Equisetum spp.

Galium boreale

Hordeum nodosum
Quamasia quamash

Rànunculus platyphyllus

Veratrum californicum

Wyethia amplexicaulis
Hypericum scouleri

Lupinus leucophyllus

Mentha canadensis borealis

Orthocarpus tenuifolius

Poa annua

Poa triflora

Polygonum emersum

Polygonum polygaloides

Potentilla rectiformus

Prunella vulgaris lanceolata 
Rumex mexicamus

Rumex occidentalis

Senecio serra

Sidalcea oregana
Steironema cilici:sn

Trifolium douglasii

Zygadenus veneniosus

In this region the associes is represented by a single consocies, namely that dominated by Deschampsia caespitosa. This characteristic grass with its densely tufted perennial stems, which often reach a height of over 3 feet, often occurs in nearly pure growth. In favorable situations, the clumps may reach a diameter of 9 inches.

The Quamasia socies is well marked in the early spring when large areas in the wet meadows are characterized by the dark blue flowers of Quamasia quamash (Fig. 32). These scapose plants, reaching a height of $2-2.5$ feet, are terminated by elongated racemose clusters of as many as 30 large, blue flowers. The individuals frequently occur as abundantly as $35-45$ in a square meter. The edible bulbs, which are nearly an inch in diameter and buried only 4 inches in the soil, are a favorite food of the Indians.

Heracleum lanatum, the cow parsnip, is very abundant in wet meadows along streams (Fig. 34). It not only reaches far above other herbaceous vegetation, but its large size and numerous, large, white-flowered umbels, which bloom for weeks, make this socies a very conspicuous one for the major part of the growing season.

Wet meadows in early spring are characterized by the great abundance of Ranunculus platyphyllus. Its great numbers, combined with its profuse flowering habit, makes this socies one of the most important of the vernal period. The plant has rather a bushy habit. Growing about 2 feet high, it often spreads at the top over a diameter of 3 or more square feet. The golden yellow flowers are 2.5 centimeters in diameter.

Many parts of the wet meadows are dominated by large areas of Iris missouriensis. The growth habit of this cosmopolitan species is too well known to need further comment here (Fig. 33).

The black sunflower, Wyethia amplexicaulis, often found in rather dry prairies, is typically at home in the wet meadows. 
Often the gregarious growths almost exclude other plants. Its larce, dark-green, shiny, resinous leaves, more than a foot long and as many as 20 on a single individual, are no less characteristic than its numerous, large yellow flowers. A single plant may occupy an area of more than 2 square feet although $20-30$ plants often occur in a single quadrat. It possesses a strong tap root, $5-9$ inches in circumference, which may penetrate the soil to a depth of over 6 feet.

The wet meadow is gradually replaced upon its higher lying borders by typical prairie species.

It should be mentioned in this place that in the drier regions large areas of low-lying ground are dominated by dense growths of rye-grasses, especially Elymus condensatus. In low ground such as dried basins of shallow ponds and where the soil is alkaline, socies of salt grass, Distichilis spicata, or of Spartina gracilis are to be found.

\section{The Flood-plain Forest Associes}

The flood-plains along the streams, because of the seasonal distribution of the precipitation, are peculiarly apt to be subjected to periodical submergence. Growing in these rich, well-watered, alluvial soils are to be found dense thickets of various trees and shrubs and occasional groves of poplars and aspens. Since the larger streams soon cut canyons into the basalt, the flood-plains are usually not extensive and the zone of tree growth is often limited, especially westward, to a mere fringe along the bank of the streams (Fig. 35). Likewise many of the smaller streams are intermittent and along these thickets of woody species are few or entirely absent. A close relationship exists between the protection from wind, afforded flood-plain areas by canyon walls and hills, and the presence or absence of trees and shrubs.

Although these flood-plain species usually occur in various mictia, however, two communities are rather well defined-the Populus consocies and the Salix-Crataegus mictium.

The Populus Consocies.-Small groves of poplars consisting of Populus tremuloides, or more rarely of Populus trichocarpa are frequent along the flood plains, especially in the less arid parts 
of the region. These usually occur in situations white the stream has a double channel or where, having abandoned ote channel, it has built up a rich alluvial flat. It is quite clear how after a spring flood the wind-blown seeds of the poplars find excellent conditions for germination in such situations and even if only a few become established the extensive underground parts of Populus tremuloides would soon increase the area dominated by trees. In this manner the trembling aspen frequently extends its territory beyond the flood-plain onto the moist, sheltered banks of canyons. I have observed one or two cases in the deeper canyons where yellow pines had established themselves among the aspens, and seemed to be replacing them.

The Salix-Crataegus Mictium.-Much larger areas of the floodplains are dominated by shrubs or trees of the following species; these may occur singly, but more often form a mictium.

\section{Alnus tenuifolia}

Amelanchier florida

Crataegus brevispina

Prunus demissa

Salix argophylla
Salix bebbiana

Salix cordata

Salix exigua

Salix scouleriana

In addition to the above dominants numerous secondary tree species and several important undershrubs should be mentioned here. The following are the most important:

$\begin{array}{ll}\text { Alnus rhombifolia } & \text { Rosa pisocarpa } \\ \text { Amelanchier cusickii } & \text { Ribes aureum } \\ \text { Betula microphylla } & \text { Salix bella } \\ \text { Cornus stolonifera } & \text { Salix lasiandra caudata } \\ \text { Crataegus columbiana piperi } & \text { Salix pyrifolia } \\ \text { Rosa mutkana } & \end{array}$

The alder sometimes becomes so abundant locally as to constitute perhaps half of the flood-plain woody vegetation. The chokecherry is never so abundant.

Of the willows, only one, Salix lasiandra caudata, assumes the proportions of a tree. As might be anticipated, the willows are usually among the first species to appear. 
ratuegus brevispina and Amelanchier florida form dense thickets, sometimes singly, but more often in mictium. FreGrently these copses are so dense as to exclude all other vegetation. In the month of May when these trees are clothed with their profuse white blossoms the flood-plains are indeed a beautiful sight. Even in winter the woodland growth along the streams, as they wind their way among the treeless hills, lends pleasing variety to the monotonous landscape.

\section{RUDERAL VEGETATION}

There are a number of plants that are regularly found in and about waste places. To this number may be added others that are regular members of certain of the preceding plant communities which now and then reveal a decidedly ruderal tendency. The following list includes the commoner plants of this nature:

\section{RUDERAL SPECIES}

Amaranthus blitoides

Amaranthus graecizans

Amaranthus retroflexus

Amsinckia intermedia

Anthemis cotula

Arctium lappa

Artemisia atomifera

Artemisia gnaphalodes

Bromus brizaeformis

Chenopodium botrys

Chenopodium album

Cirsium lanceolatum

Collinsia tenella
Dipsacus sylvestris

Erigeron canadensis

Erodium cicutarium

Geranium pusillum

Madia glomerata

Marrubium vulgare

Matricaria matricarioides

Polygonum aviculare

Salsola kali temuifolia

Sanguisorba annua

Sisymbrium altissimum

Vaccaria vaccaria

Verbascum thapsus

Because of the practice of alternating a crop of wheat with summer fallow nearly half of the farmed area is laid bare each year for the invasion of ruderals. Amaranthus graecians and $A$. retroflexus are the dominant weeds of these fallow fields, Unless the ground is frequently tilled these grow in great abundance, the former breaking loose near the surface of the soil in 
the fall of the year and tumbling over the ground, is piled by the wind into great heaps on the leeward slopes of the hills.

Westward, in the drier regions, and especially in the scab-lands, Sisymbrium altissimum, locally known as Jim Hill mustard, from its introduction along the right of way of the railroads, is present to a degree almost unbelievable. Hundreds of acres in the scab-lands are literally "taken" by this weed. From dwarfed specimens a few centimeters high on the scab-rock, it ranges to rank growths in the moist soil. It is a bad weed in the wheat fields throughout the greater part of the region.

The tar weed, Amsinckia intermedia, is likewise a troublesome weed along roadsides and especially in wheat fields. South of Snake River it is very abundant. Its dense coat of long bristly hairs upon drying becomes extremely annoying to both men and horses.

Westward and especially in the slightly alkali regions the Russian thistle, Salsola kali tenuifolia, and the Australian salt bush, Atriplex semibaccata, are often abundant.

Dipsacus sylvestris, introduced a number of years ago, has spread very rapidly and in many localities assumes the rôle of a very thrifty and very obnoxious weed.

The little geranium, Erodium cicutarium, is an introduced weed which has become very common in gardens, feed lots, and waste places. Often associated with it are Sanguisorba annua, Geranium pusillum, and Verbascum thapsus.

Common roadside weeds of especial abundance are Madia glomerata, Marrubium vulgare, and the rattle grass, Bromus brizaeformis. The absence of most roadside weeds so common in the eastern and central states is very characteristic.

About the numerous grain-loading stations throughout the region many ruderals are gaining a foothold. Here the cars are swept out and the seeds of various plant species scattered. Among other weeds thus recently introduced, and which I have seldom seen elsewhere, may be mentioned Ambrosia trifida, A. psilostachya, Melilotus alba, $M$. officinalis, Cirsium arvense, Iva xanthifolia, Datura tatula, and Datura stramonium. The problem of grain warehouses as centers of weed distribution would 
form in itself an intensely interesting and very practical field of investigation.

\section{CONCLUSION}

In the foregoing pages it has been shown that in this region lying in southeastern Washington and adjacent Idaho, three plant formations occur. In the western part of the region, that of least elevation and consequently of lowest precipitation, the desert scrub formation occurs. As the altitude becomes greater and the climatic conditions more favorable eastward, the desert scrub gives way to the grass land of the prairie-plains formation. In its early development this grass land is of a very open bunch-grass type, with much of the ground being either destitute of vegetation or carpeted with interstitial plants only in early spring. As conditions become less xerophytic at higher altitudes the ground becomes rather completely occupied by grasses, some of which are sod-formers, and by non-grassy herbaceous vegetation which shows a great increase both in the number of species and in the number of individuals per unit area. The best developed prairies reveal a potential shrub community which, while held in check usually by competition with prairie plants, develops in the eastern edge of the grass lands and especially upon the non-basaltic soils into thickets of chaparral. Under cover of the chaparral, the yellow pine, a pioneer community in the development of the Pacific Coast forests, often becomes established. The pine may be replaced by Douglas fir and tamarack, and these in turn by mixed communities dominated by tamarack and white fir, or by white fir and cedar. Finally, in the most mesophytic areas the cedar community reveals the climax stage in the development of the Pacific Coast forest formation.

It has been shown that the desert scrub formation is characterized by soils with lower water content and higher temperature, and with higher evaporating power of the air than any of the other plant communities. Likewise, there has also been found to exist in the several plant communities of the xerosere, from the bunch-grass community of the prairies to the climax cedar community of the forest, a direct relation between the water content 
of the soil, the temperature of the soil and the evaporating power of the air, and progressive stages in succession. The water content of the soil has been found to vary directly with the stages of the sere from a minimum in the bunch-grass stage to a maximum in the cedar community. Conversely, the soil temperature and the evaporating power of the air have been shown to decrease directly in proportion to the advancement of the stage of development of the sere.

In the forest communities the light values decrease progressively as the climax community is approached.

In addition to the xerosere, beginning with lichens and mosses on the bare rocks of basalt, granite, or quartzite and ending ultimately in the climax forest community, we have also traced the stages of the subsere in the reëstablishment of cut-over or burnedover forested areas. We have seen how these more or less denuded areas may finally come to support the same type of vegetation that characterized them before the disturbance of their normal development.

Lastly, we have considered the hydrosere. The communities of this sere, although occupying a relatively small area geographically, show distinct stages from the submerged, floating and swamp communities to that of the wet meadow. The latter is usually replaced by a xerophytic grass land community, or infrequently by a deciduous flood-plain forest.

In concluding this report on the study of the vegetation of southeastern Washington and adjacent Idaho, the writer wishes to state that perhaps no one feels more keenly than he the necessarily preliminary nature of the work accomplished.

The Snake River Canyon alone, with its peculiarly dry, mild climate stands in marked contrast to the colder, more humid area above, and forms a rich field for detailed ecological investigation. Not infrequently has the writer spent days in late February or early March among the abundant prevernal flora of the canyon, while weeks later most of the same species came into blossom on the plateau above, while yet another period elapsed before the

awakening of the same species on butte and mountain prairies.
During the progress of this study a number of plant species 
not reported for the region were encountered. Among these the occurrence of the devil's club, Echinopanax horridum, along certain streams in Thatuna Hills, is especially interesting. Many of the species new to the region are ruderals. Other plants like Crataegus columbiana piperi, heretofore known to occur only in Washington, were also repeatedly found in Idaho.

It is hoped that the results of the present research may form a basis for further investigation of the ecological problems of this and adjoining regions.

\section{LITERATURE CITED}

1. Calkins, F. C.-Geology and Water Resources of a Portion of Eastcentral Washington. Water-supply paper U. S. Geological Survey No. $118,1905$.

2. Clements, F. E. Plant Succession. Carnegic Inst. Wash. Publ., 242, 1916.

3. Frye. Theodore C, and Rigg. George B. Northwest Flora, 1912.

4. Fuller, George Damon. Evaporation and Plant Succession. Bot. Gaz., 52: 193-208, 1911.

5. Fuller, George Damon. Evaporation and Soil Moisture in Relation to Succession of Plant Associations. Bot. Gaz., 58: 19.3-234. 1914.

6. Humphrey, Harry B., and Weaver, John Ernst. Natural Reforestation in the Mountains of Northern Idaho. Plant World, 18: $3 \mathrm{t}-48$, 1915.

7. Hoffman, Julius V. Natural Reproduction of Coniferous Forests. Univ. Minn. Studies Biol. Sci., I.

8. Landes, Henry. Underground Waters of Washington. Water-supply and Irrigation Paper, No, 111, 1905.

9. Piper, Charles V. Flora of the State of Washington. Contributions from the U. S. National Herharium, 11: 1006.

ro. Piper, Charles V., and Beattic, R. Kent. Flora of the Palouse Region, roor.

1I. Piper. Charles V., and Beattic, R. Kent. Flora of Southeastern Washington and Adjacent Idaho, 1914 .

12. Russell, I. C. Principal Features of the Geology of Southeastern Washington. Mining, 3: 163-165, 1897.

13. Russell, I. C. Reconnaissance in Southeastern Washington. U. S. Geol. Sury. Water-supply and Irrigation Paper No. 4, 1897.

14. Russell, I. C. Geology and Water Resources of the Snake River Plains of Idaho. Bull. U. S. Geol. Surv., No. 199. 1902.

15. Turesson, G. Slope Exposure as a Factor in the Distribution of 
Pseudotsuga taxifolia in Eastern Washington. Bull. Torr. Bot. Club, 4I : 337-345, 1914.

16. Weaver, John Ernst. Evaporation and Plant Succession in Southeastern Washington and Adjacent Idaho. Plant World, 17: 273294, I9I4.

17. Weaver, John Ernst. A Study of the Root-systems of Prairie Plants of Southeastern Washington. Plant World, 18: 227-248 and 273292, 1915 .

18. Whitford, H. N. The Forests of the Flathead Valley, Montana. Bot. Gaz., 39: 99-122, 194-218, 276-296, 1905. 


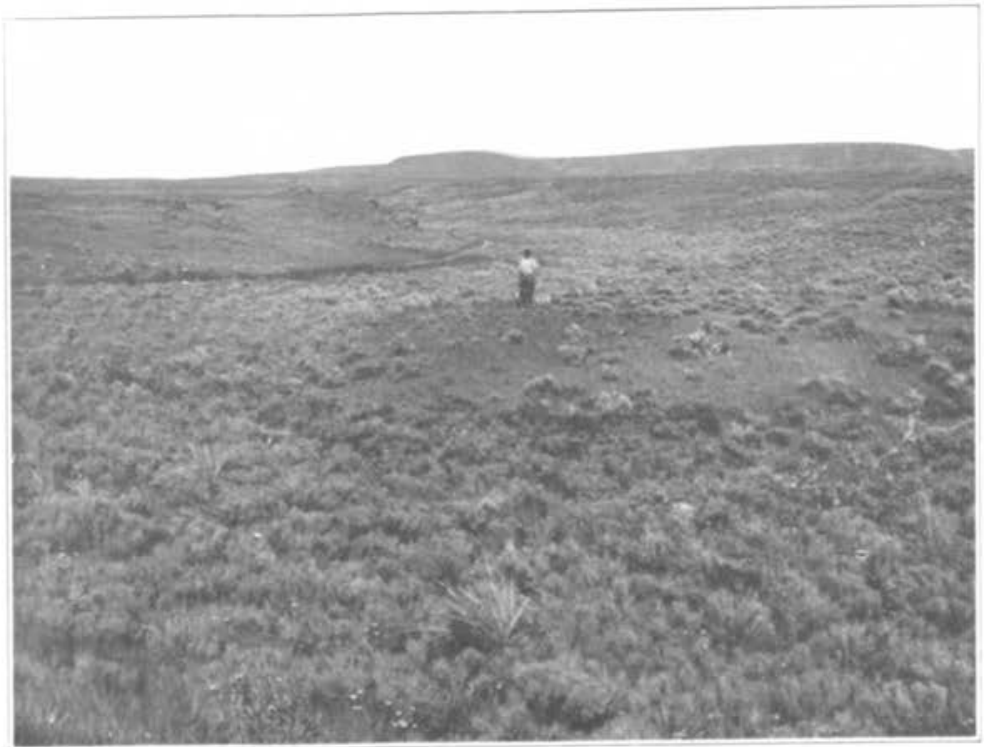

Fic. 16. Typical view in the sagebrush community. The chief plant is the scab-land sage. Artemisia rigida. The hills in the background are covered with bunch-grass.

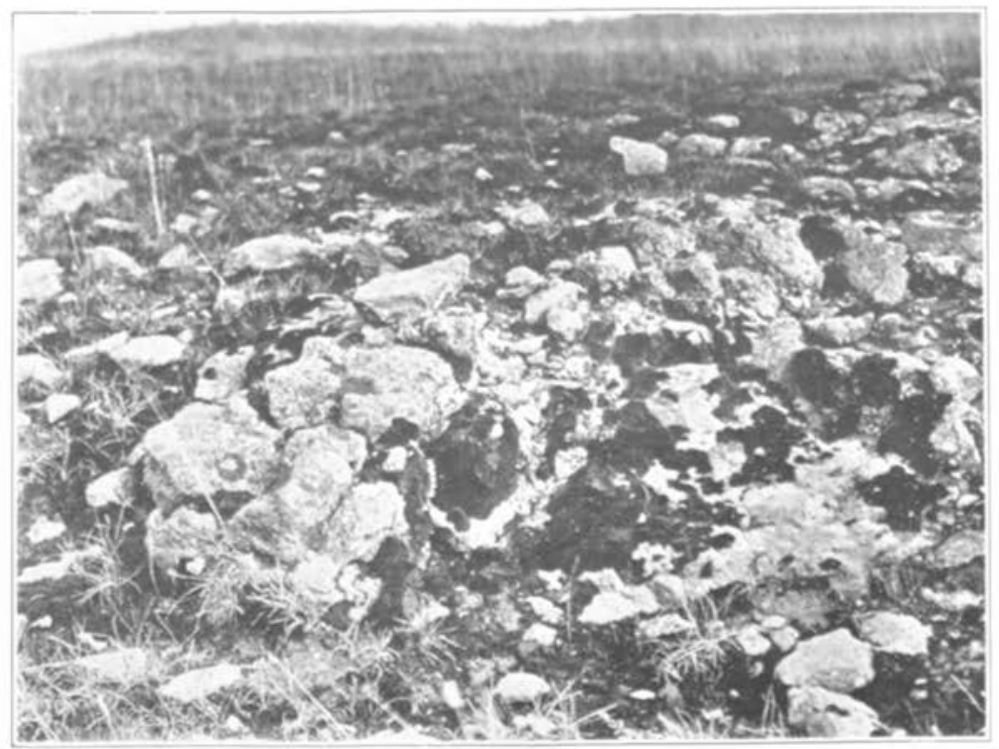

FIG. 17. A glimpse of the lichen-moss community. The black mats are Grimmia montana. Surrounding the base of the rocks and extending along the deeper crevices are patches of Tortula into which the June grass is invading. 


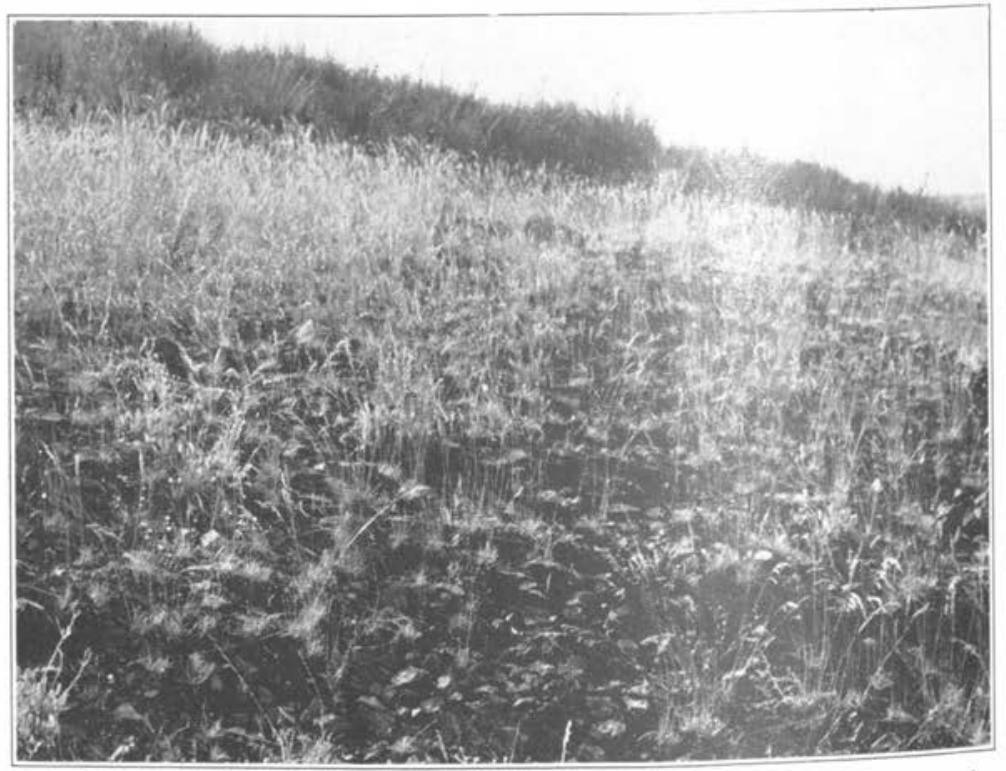

FiG, 18. June grass and knotgrass on thin rocky soil. Note the bunchgrass occupying the deeper soil in the background.

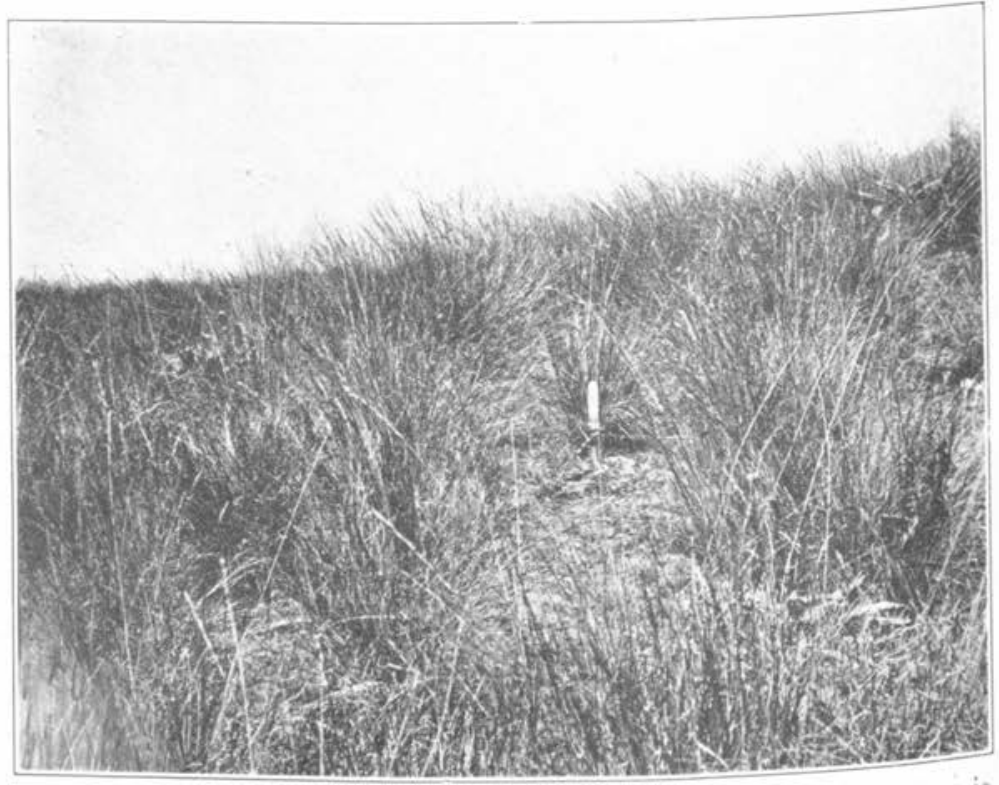

FIG, 19. A typical bunch-grass community. Much of the soil surface is unoccupied. 


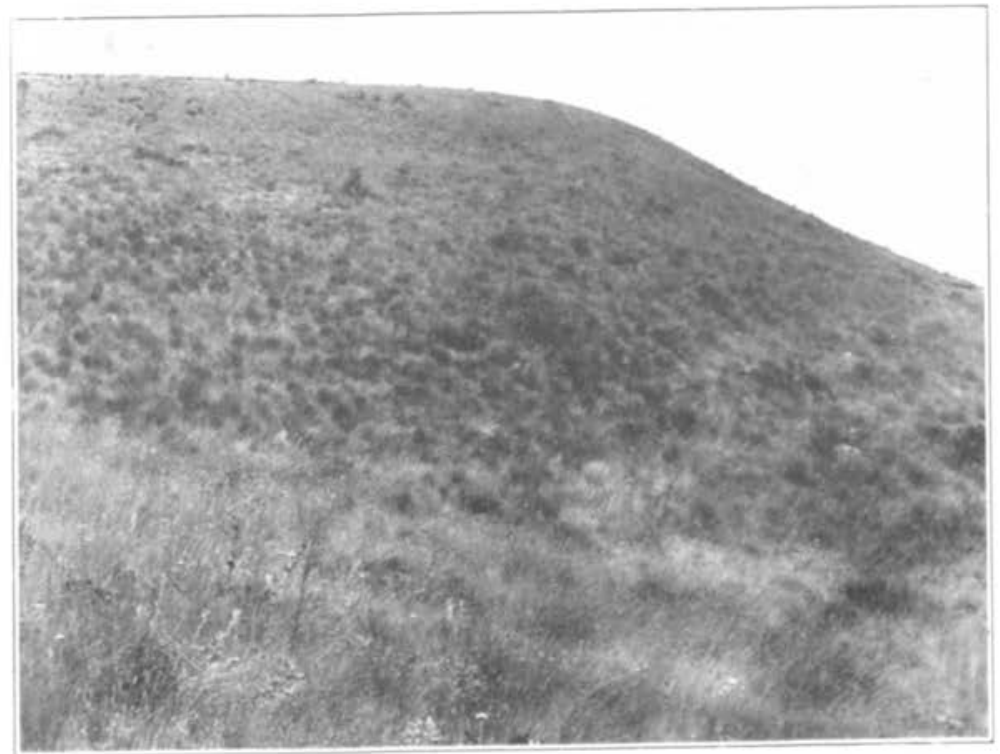

FIG. 20. A hillside in Garfield County clothed with plants of the Agropyron consociation. Typical representation of the drier type of prairie.

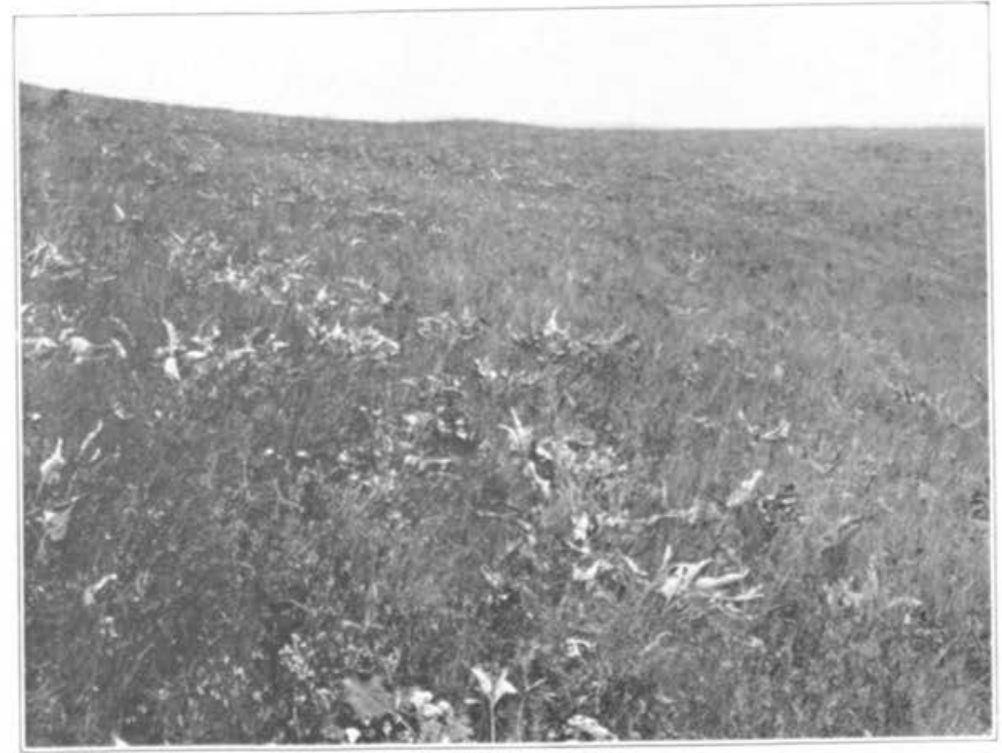

Fig. 21. Festuca consociation in eastern Whitman County; representative of the less xerophytic type of prairie. 


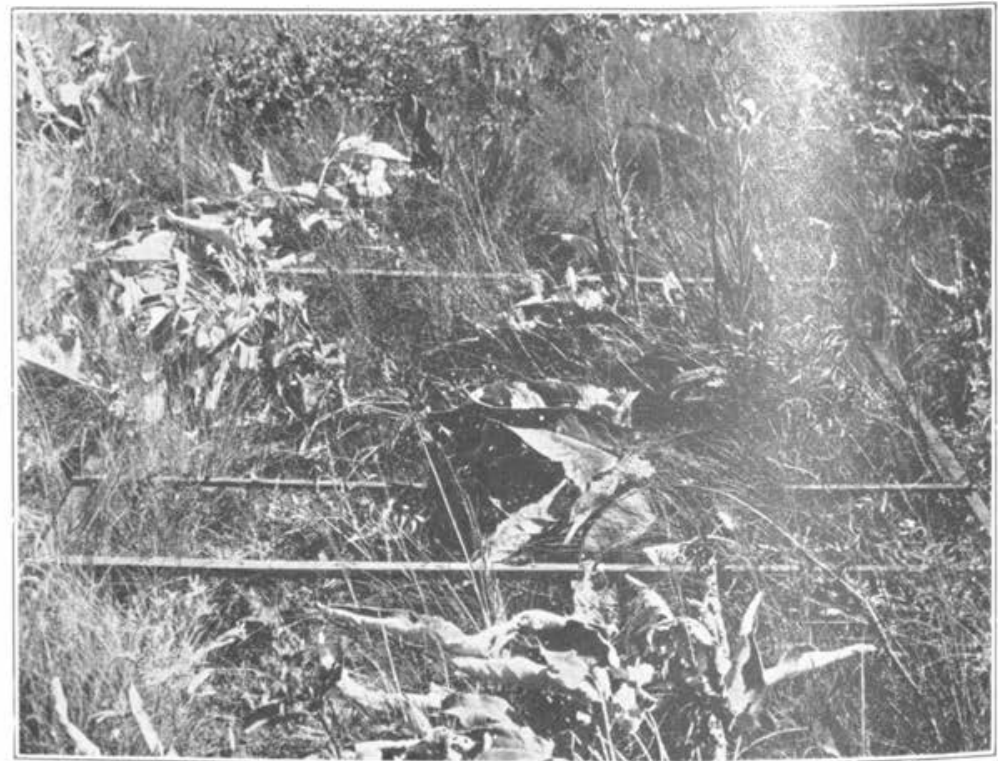

FIG. 22. Minor quadrat in the Festuca consociation. The conspicuous plants are Balsamorhiza sagittata, Hieracium scouleri, and Festuca ovina ingrata.

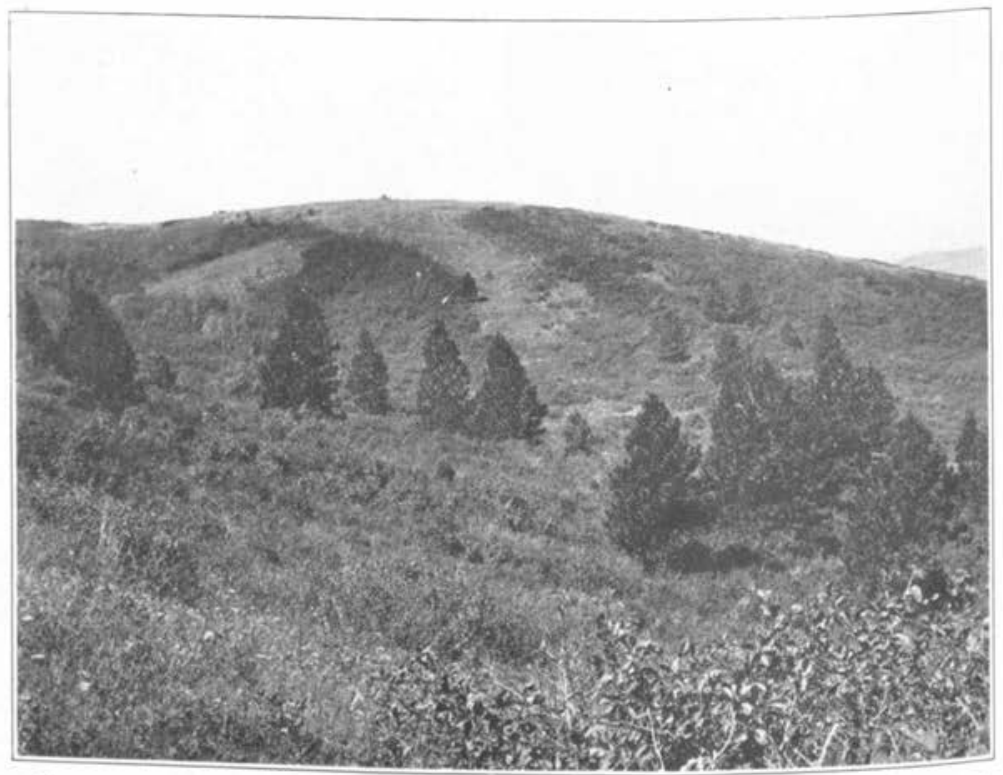

Fig, 23. Yellow pines invading a protected north slope under cover of the ninebark, Opulaster pauciflorus. The exposed south slope is covered with prairie, tongues of which extend down the dry ridges shown in the picture. 


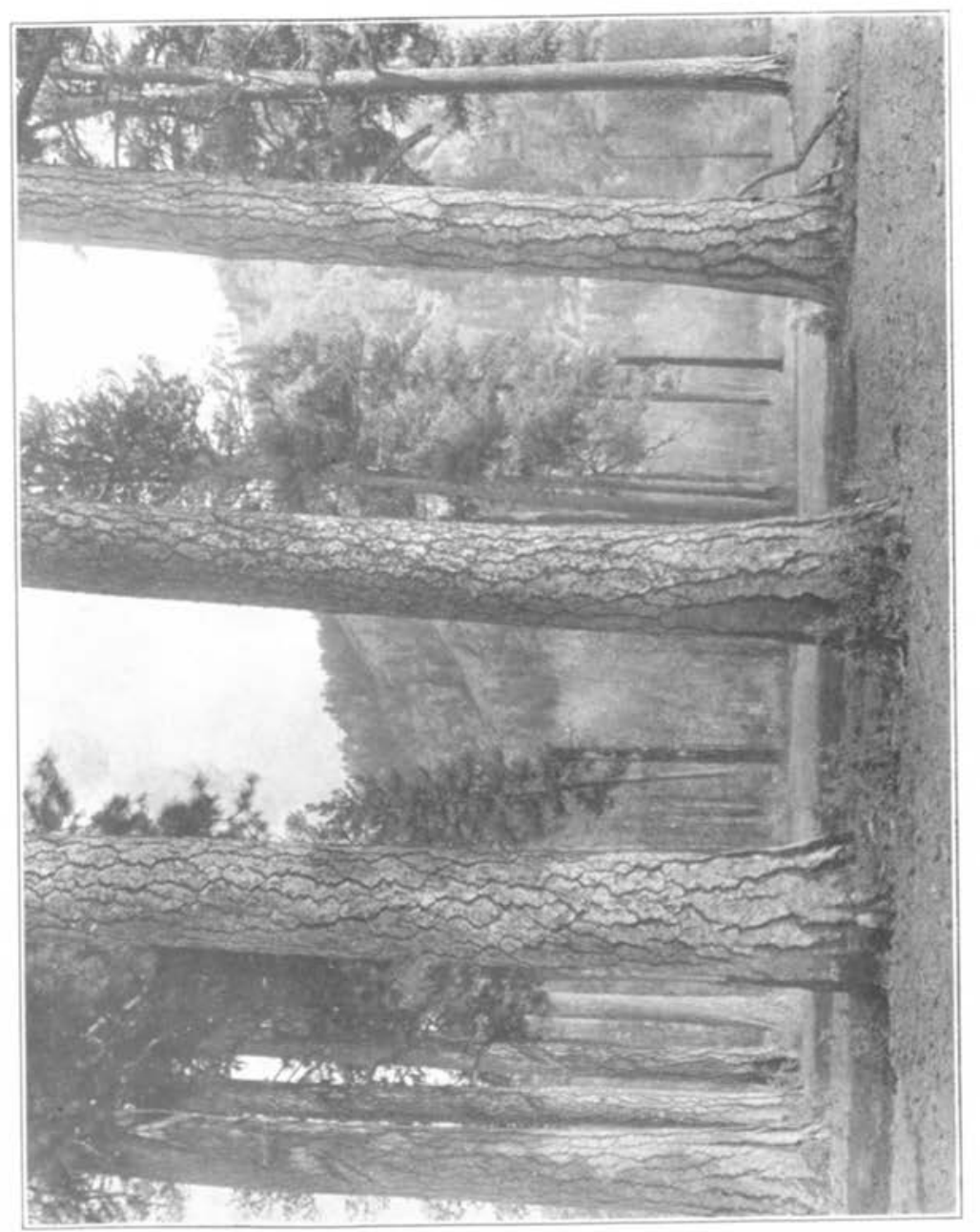




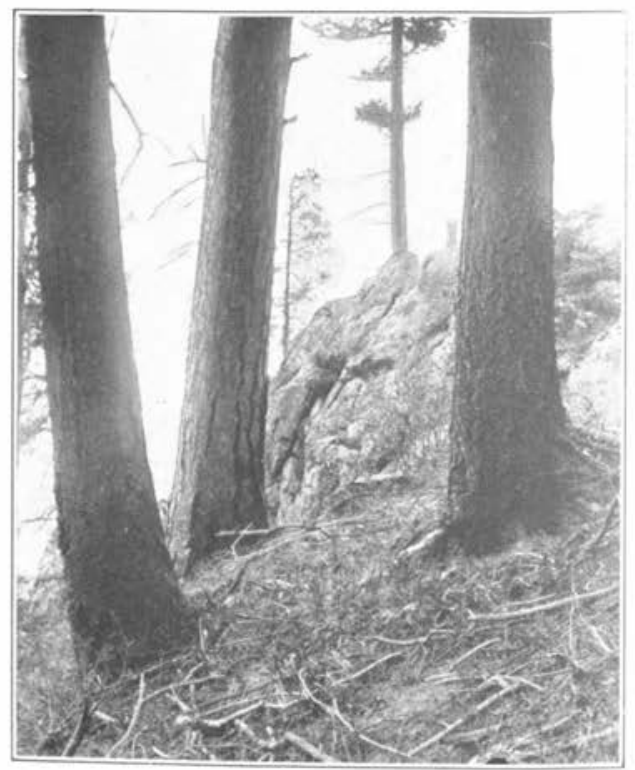

FiG, 25. Douglas fir and yellow pine on an exposed rocky slope in the mountains.

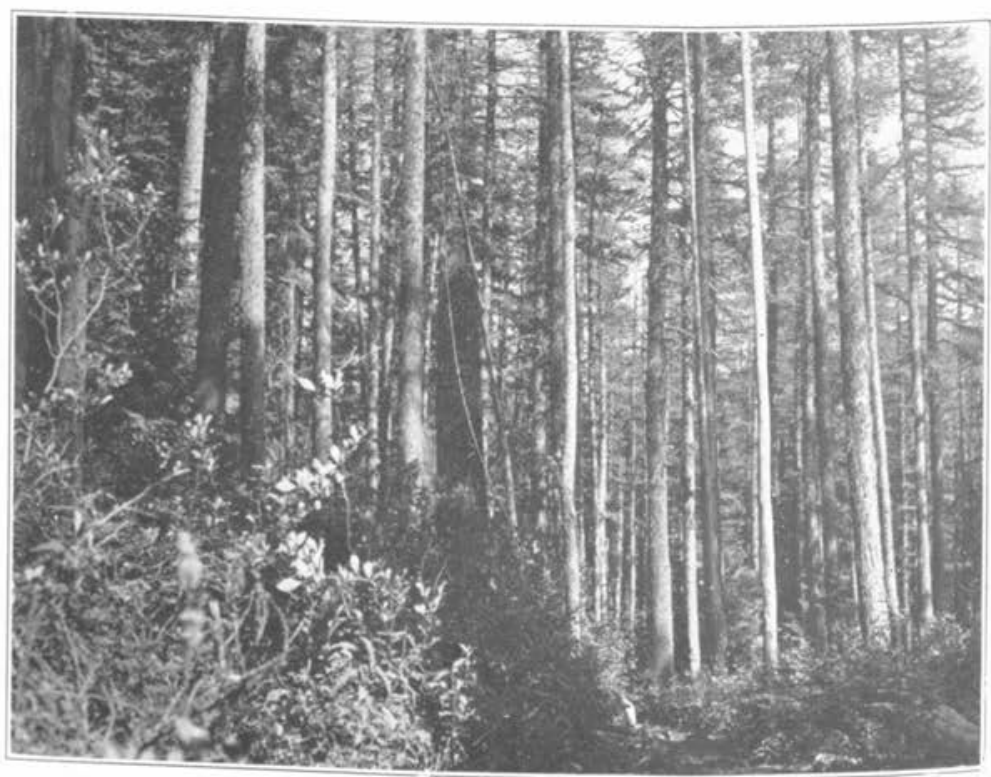

FIG. 26. A mixed forest of Douglas fir, tamarack, and white fir. 


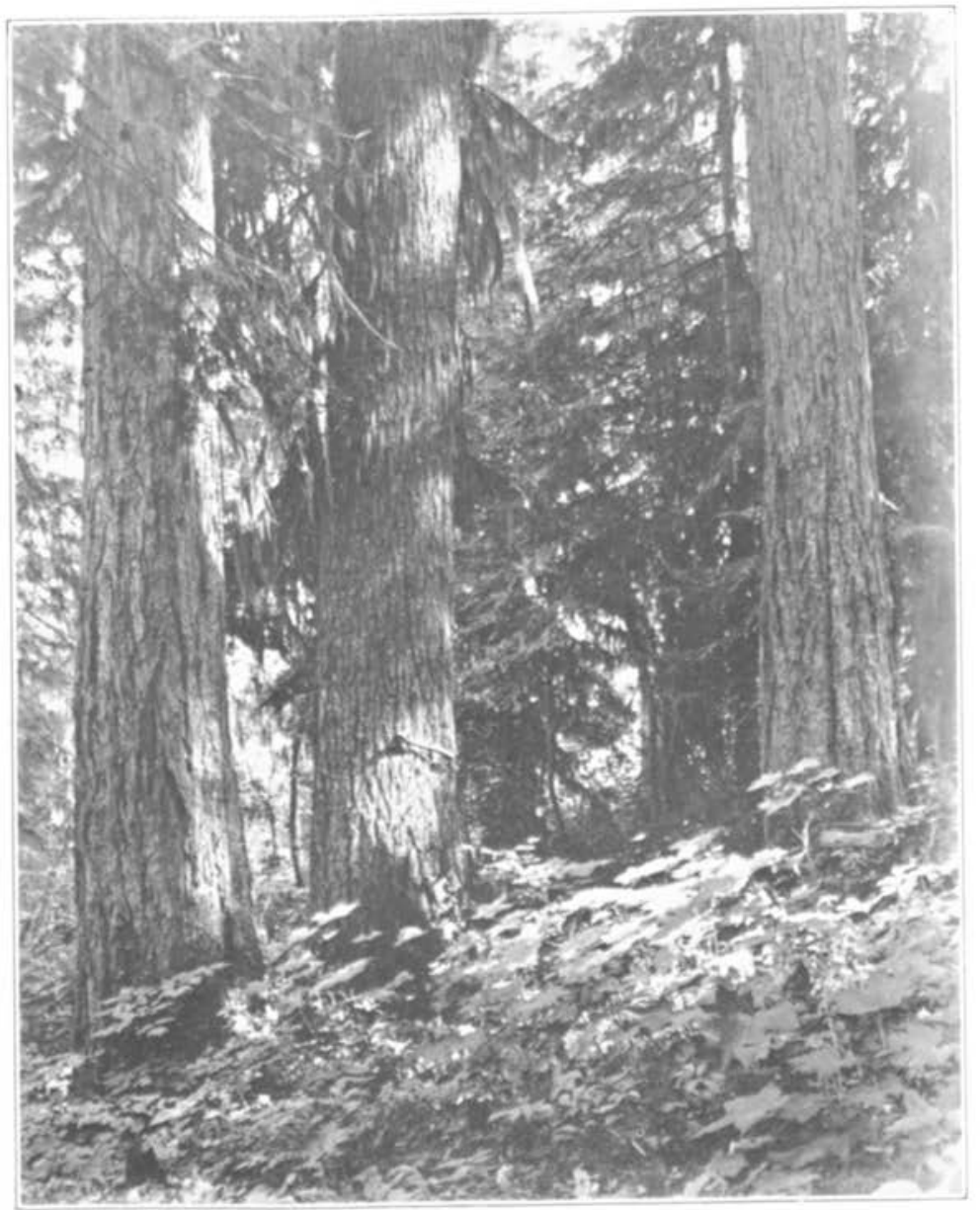

Fig, 27. A glimpse into a primeval forest of Lari, Abics, and Thuja. 


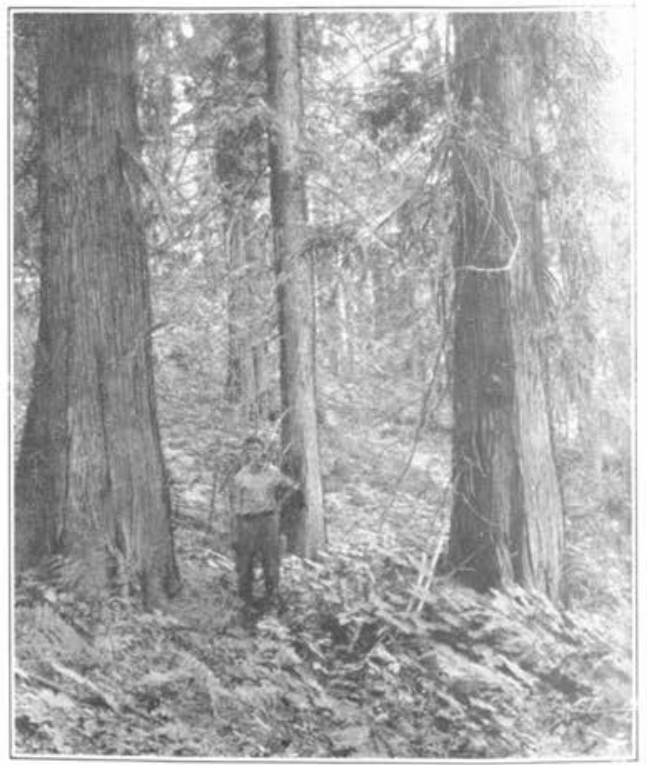

FIG. 28. Climax Thuja consociation. In such situations the light is too low to permit the growth of tree seedlings other than the cedar.

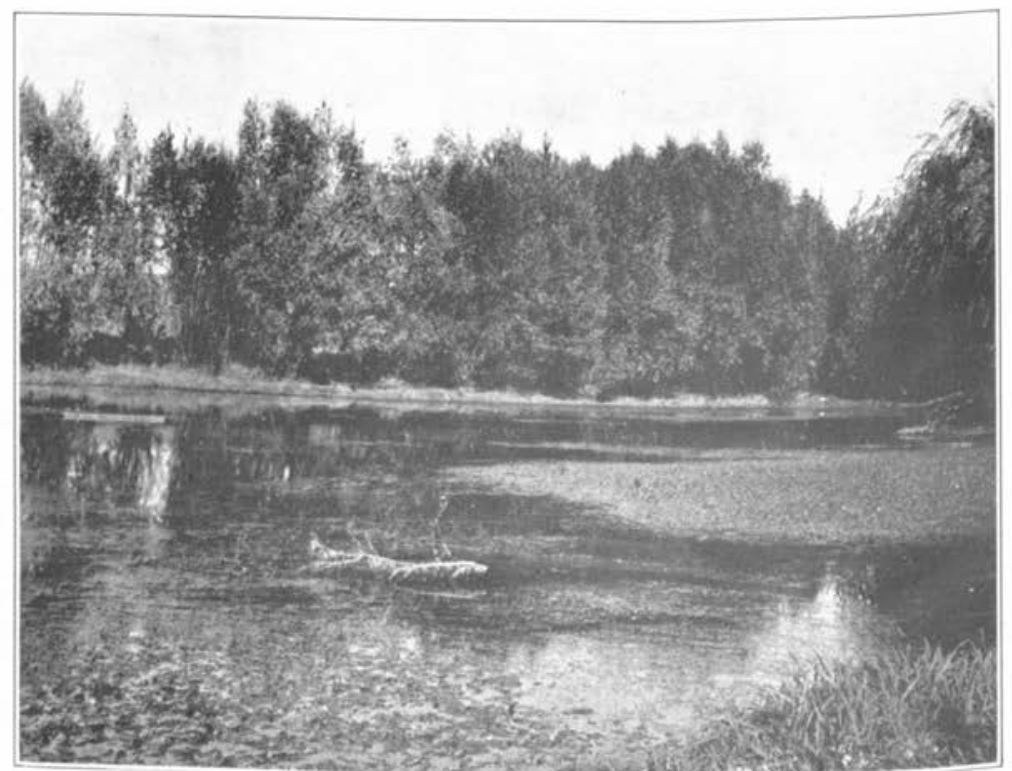

FIG. 29. Potamogeton consocies in Silver Lake. The chief species is Potamogeton americanus. Willows fringe the margin of the lake. 


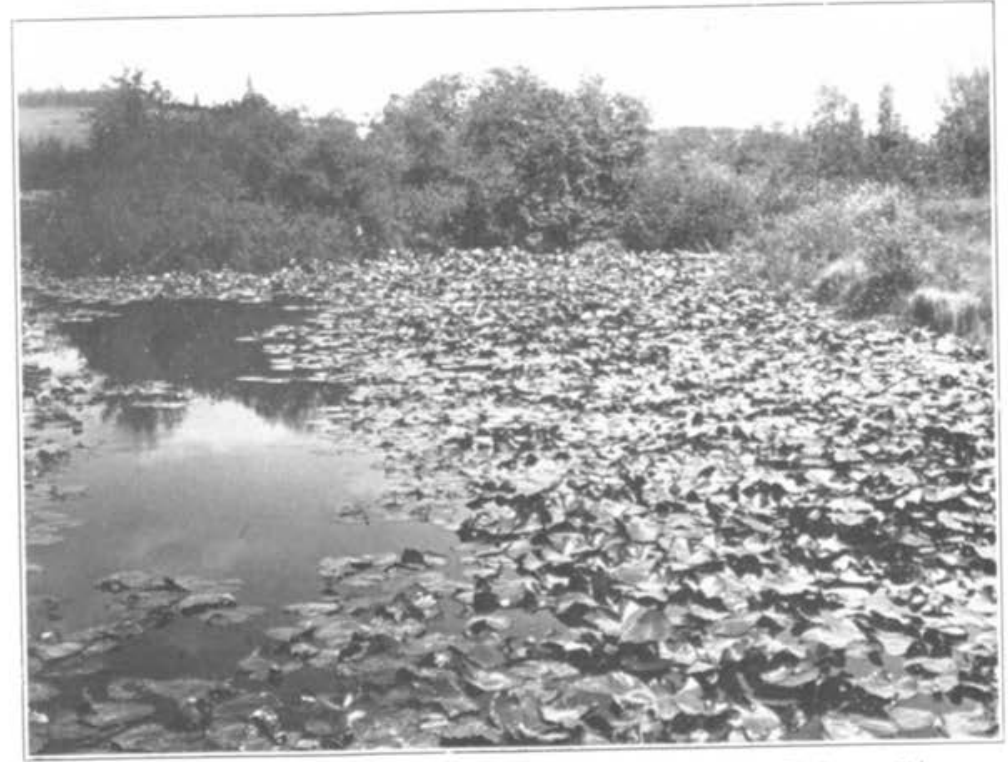

FIG. 30. A consocies of Nymphaca in a lagoon of the Palouse River.

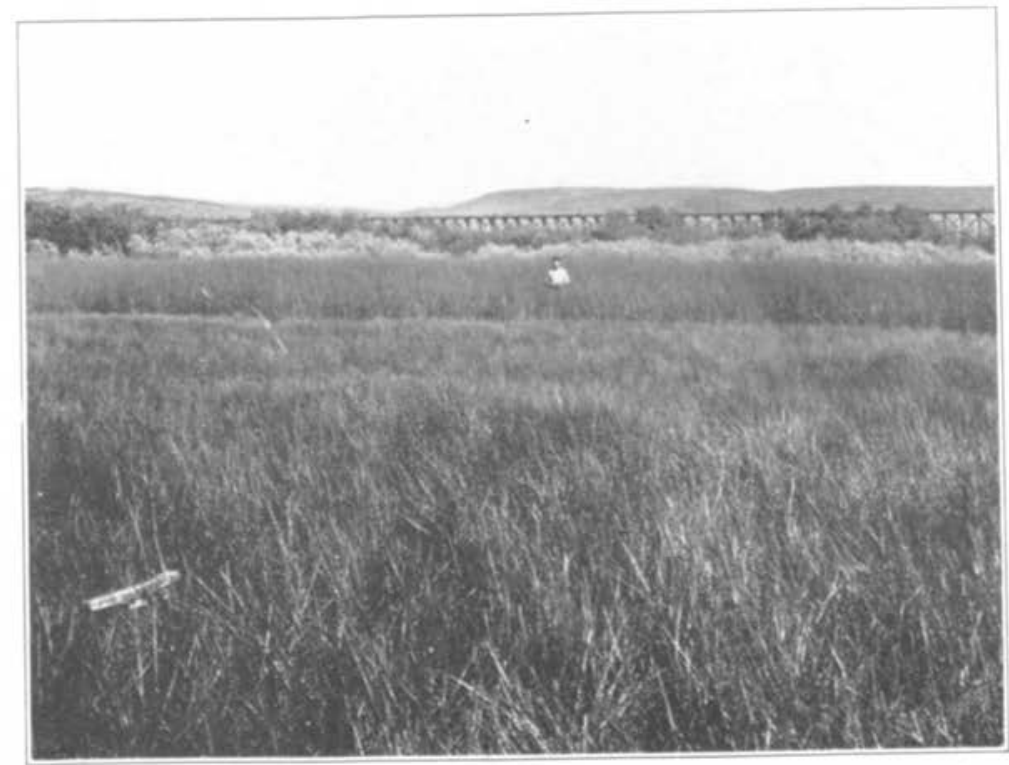

Fig. 31. View near Rock Lake showing zonation of Eleocharis palustris (foreground) and Scirpus microcarpus. In the background are floodplain trees of willow, hawthorne, and Amelanchicr. 


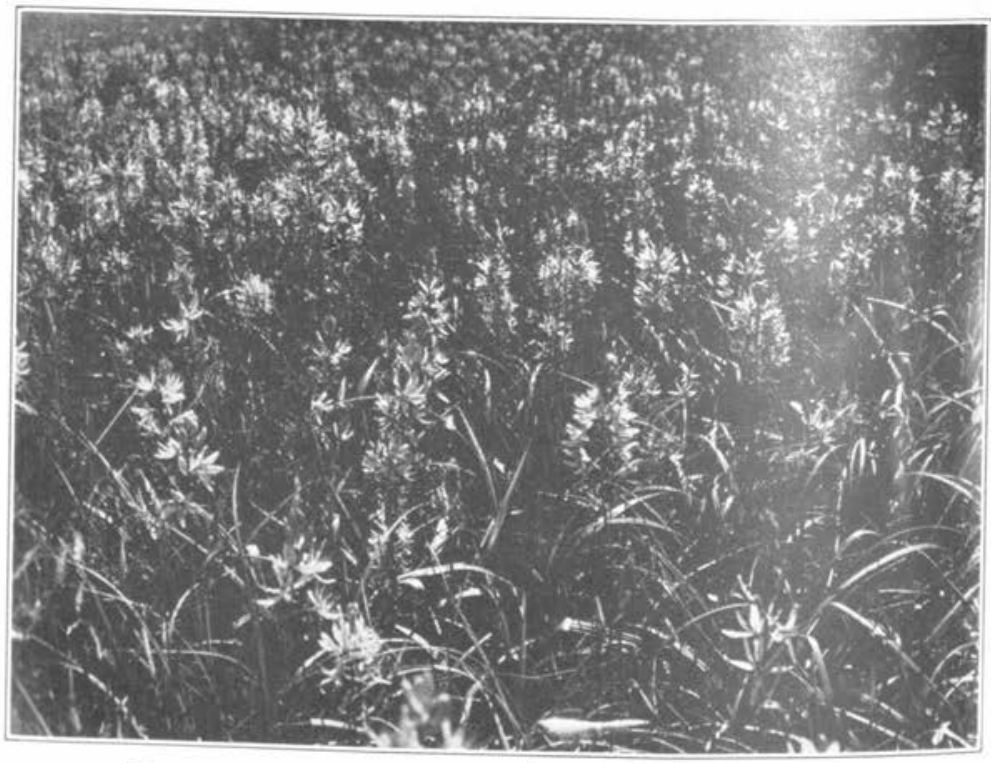

FIG. 32. A wet meadow socies of Quamasia quamash.

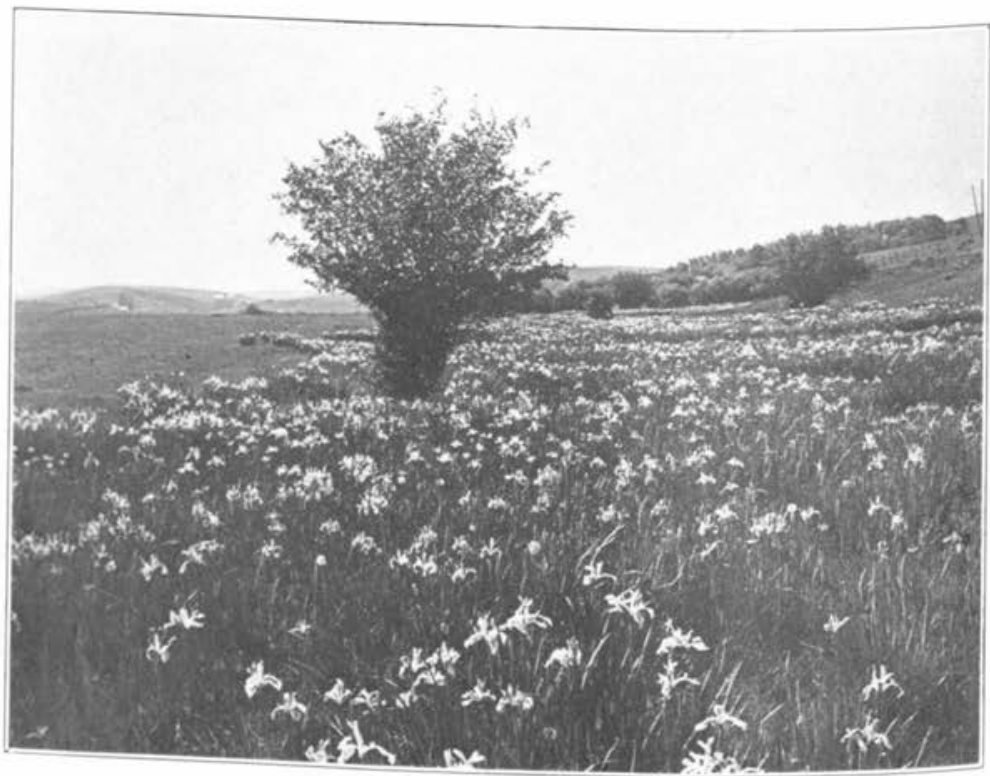

FIG. 33. A socies of Iris missouriensis. 


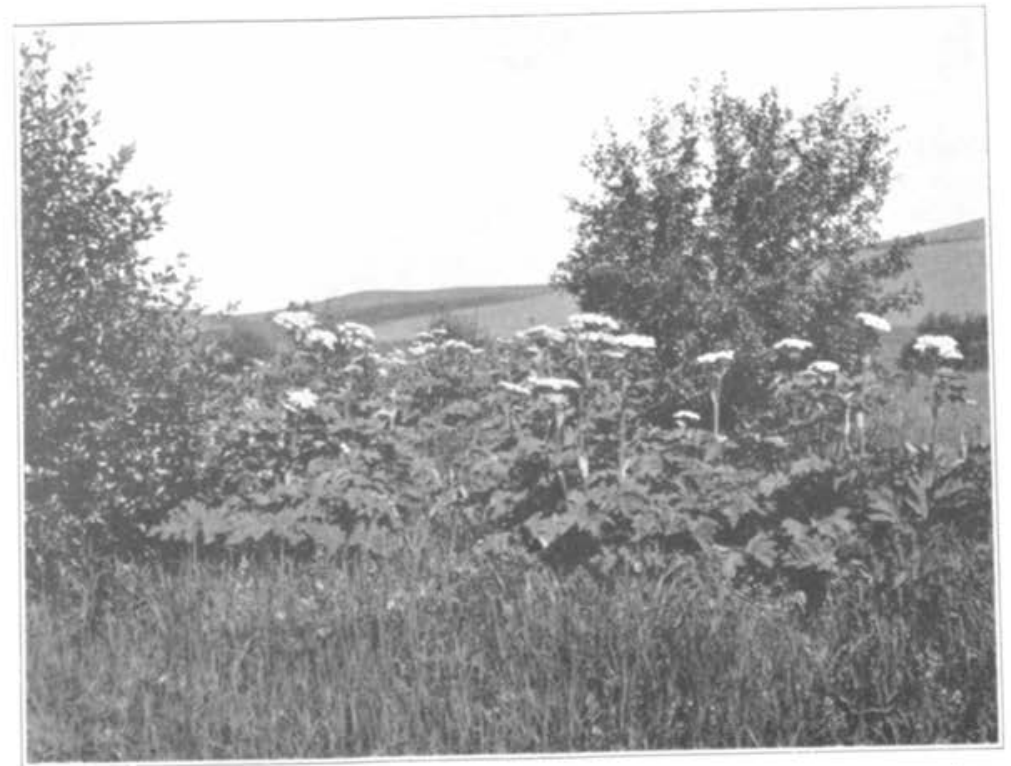

FIc. 34. Heracleum lanatum and Cratacgus brevispina in a wet meadow.

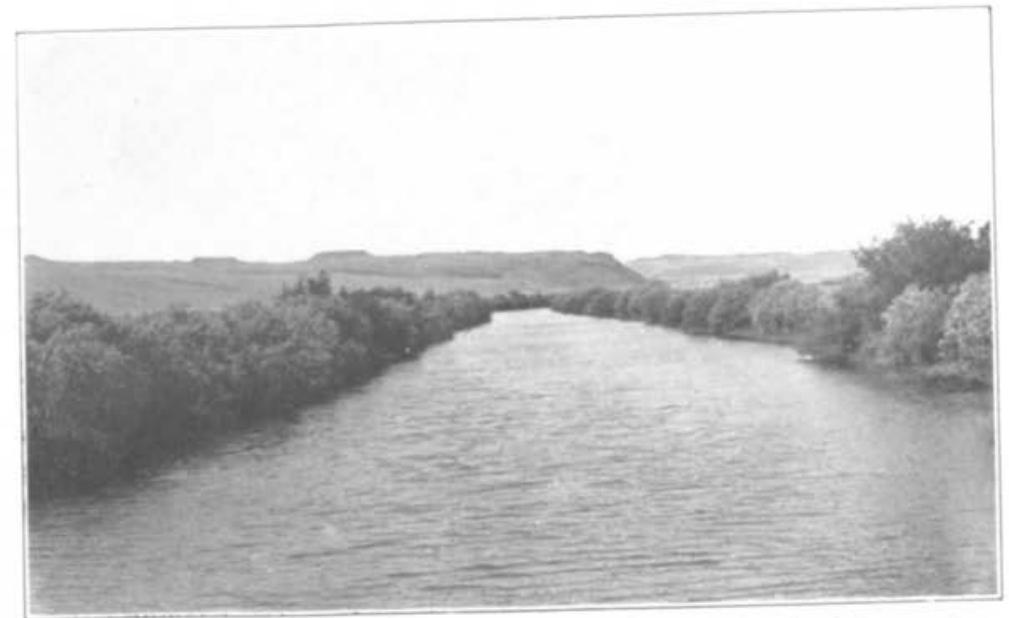

FIG. 35. A view of the flood-plain trees along Rock Creck in western Whitman County. The chief trees are Bctula microphylla, Crataegus brevispina, and species of Salix. 


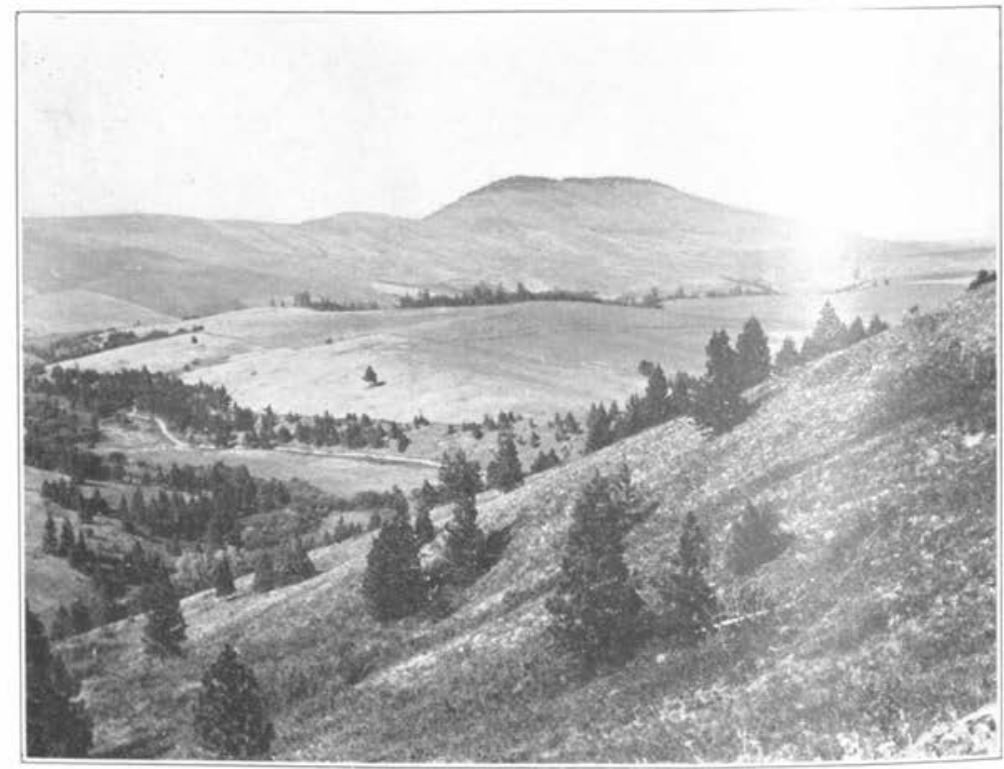

Fig. 36. A view of Kamiak Mountain looking northward from Smoot Hill. Note the fringe of pines near the summit of the exposed south slope.

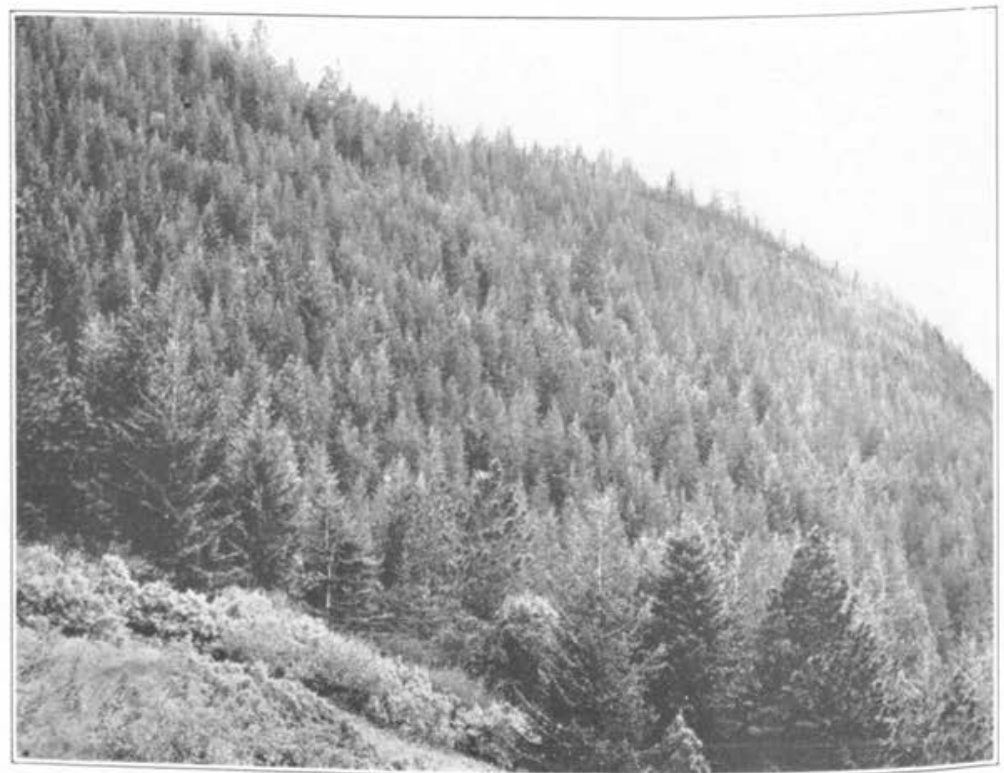

FIG. 37. The north slope of Kamiak Mountain. It is covered with a second-growth forest of Douglas fir and tamarack. 


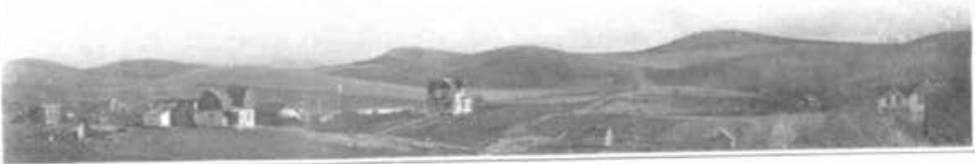

FIG. 38. A bit of skyline at Pullman. Washington, showing the rounded, flowing outlines of the dune-like topography.

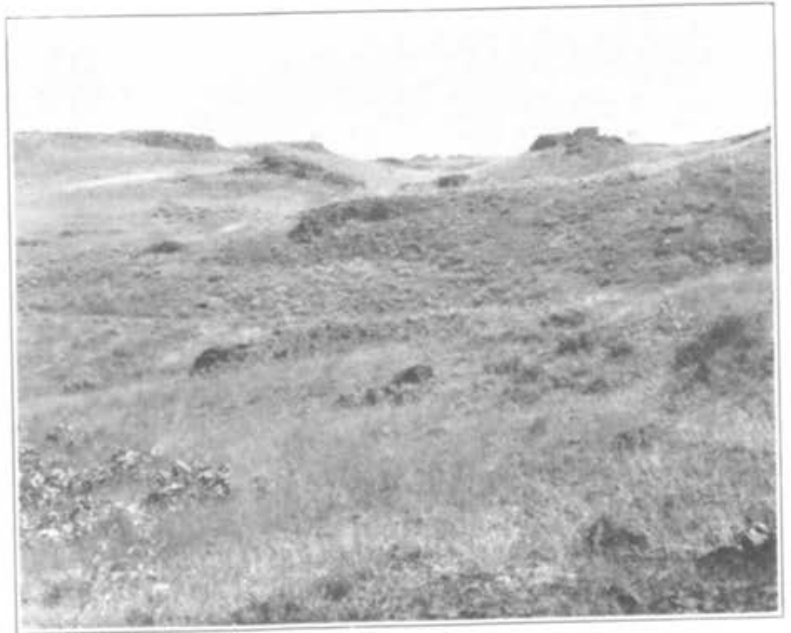

Fig. 39. A view in the scab-lands in eastern Adams County. A distance of a few feet may show a change of vegetation from the lichens and mosses on the rocks to the June grass-knot-grass or sagebrush communities. Likewise, the bunch-grass and balsam-root of the drier soil gives way to more mesophytic species in the depressions.

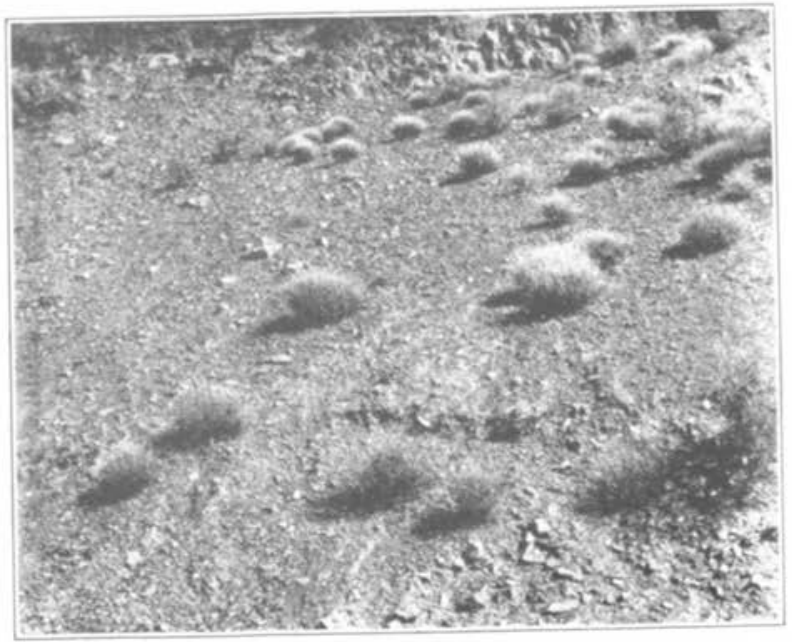

FIG. 40. A family of knot-grass invading a newly formed talus slope. 


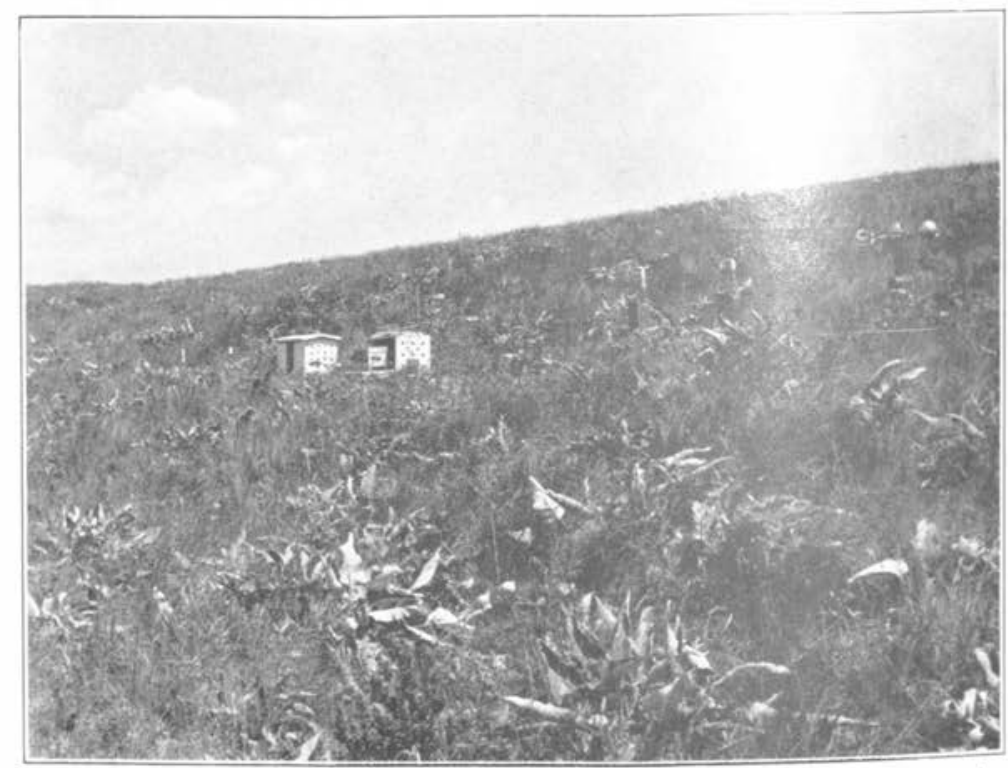

Fig, 4t. Base station in the Festuca consociation near Pullman, Wash.

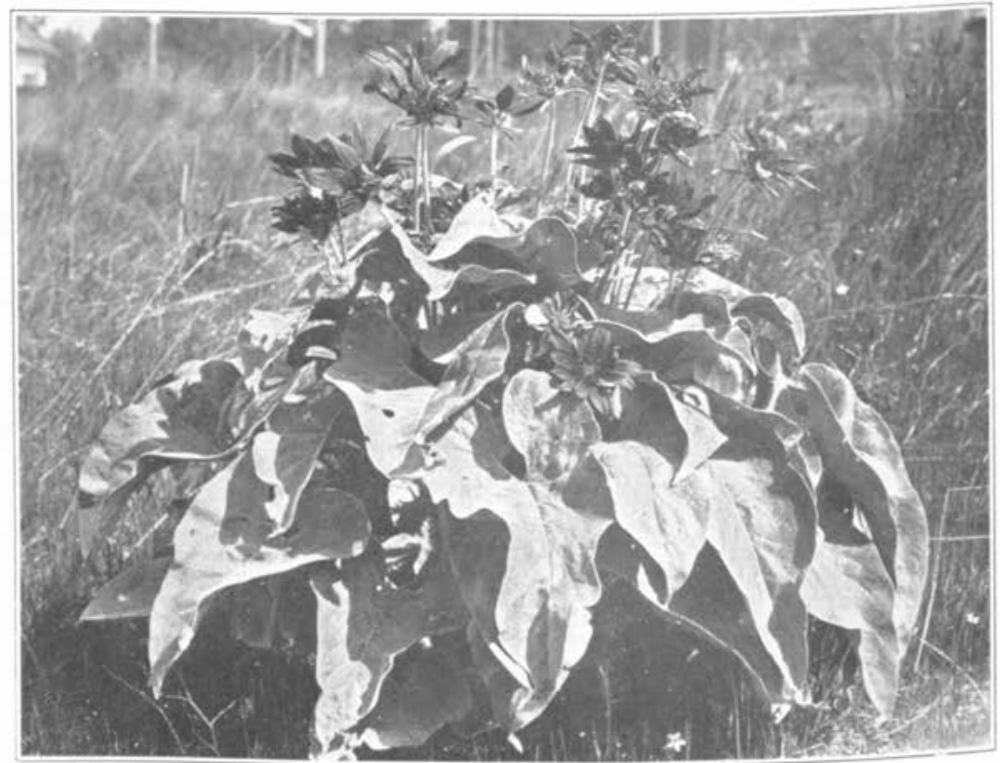

FIG. 42. A single plant of Balsamorhisa sagittata. 


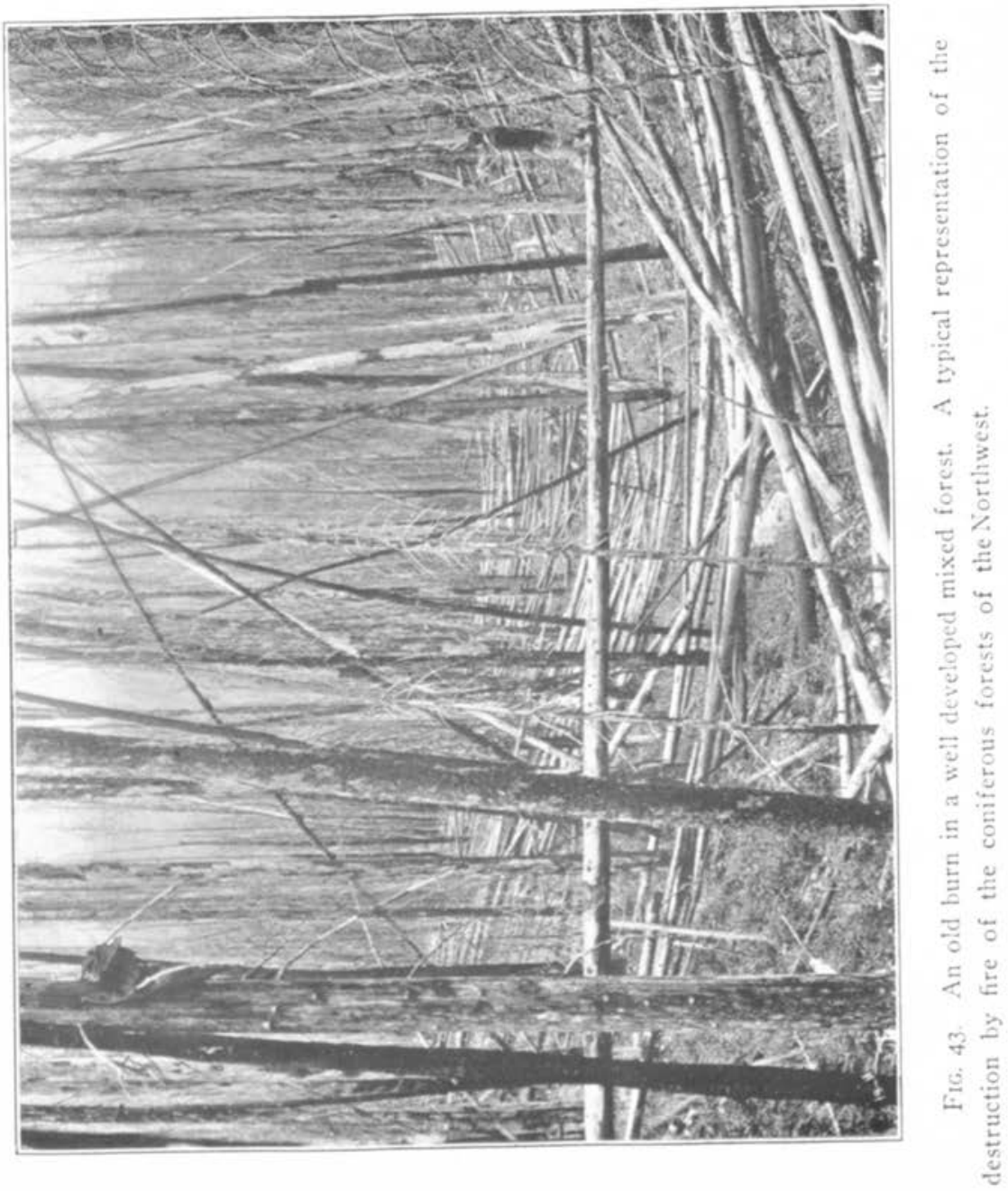




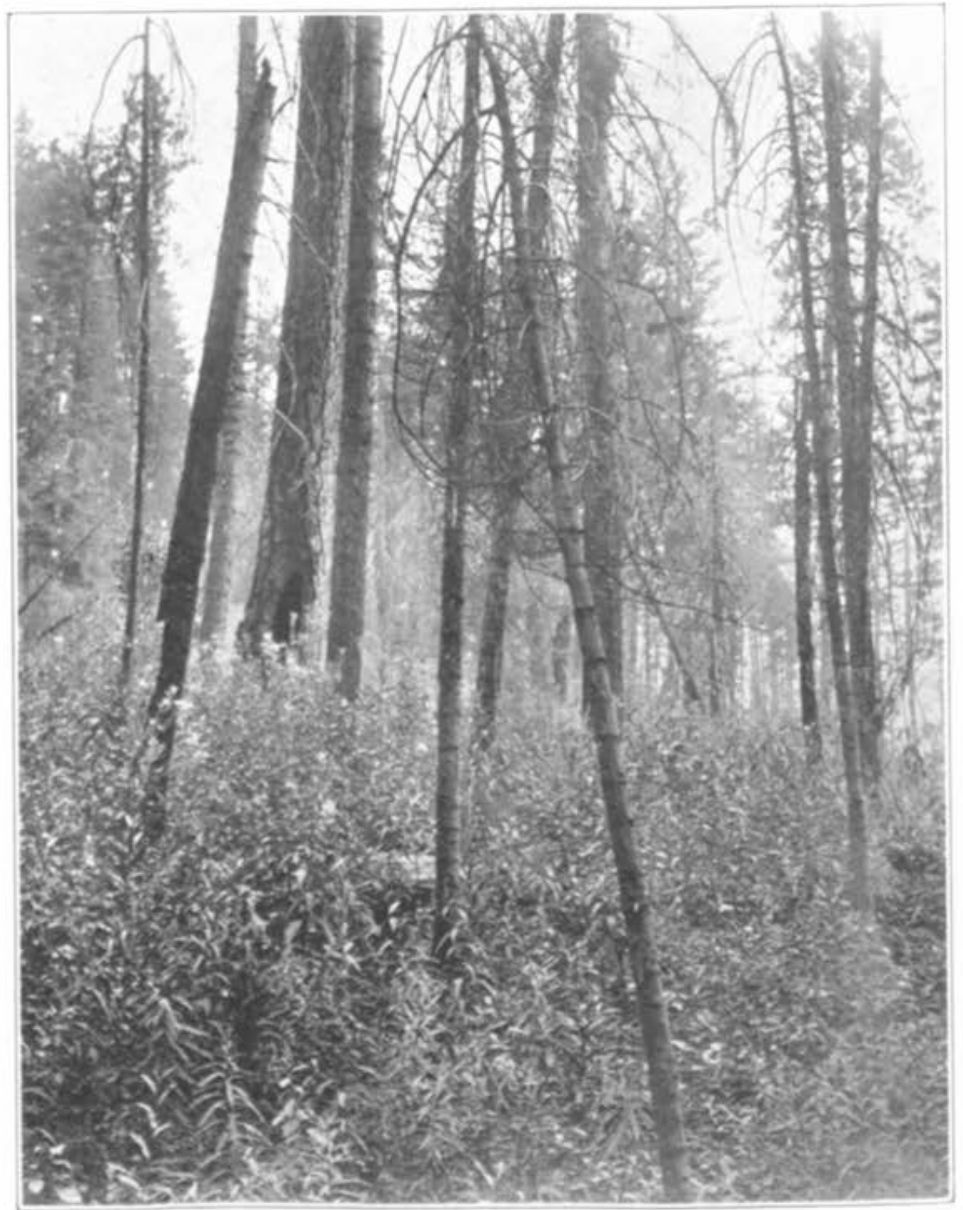

FIG. 44. A five-year-old burn on a dry slope in Thatuna Hills. Under the cover of the fireweed numerous seedlings of yellow pine, Douglas fir, and tamarack are to be found. 


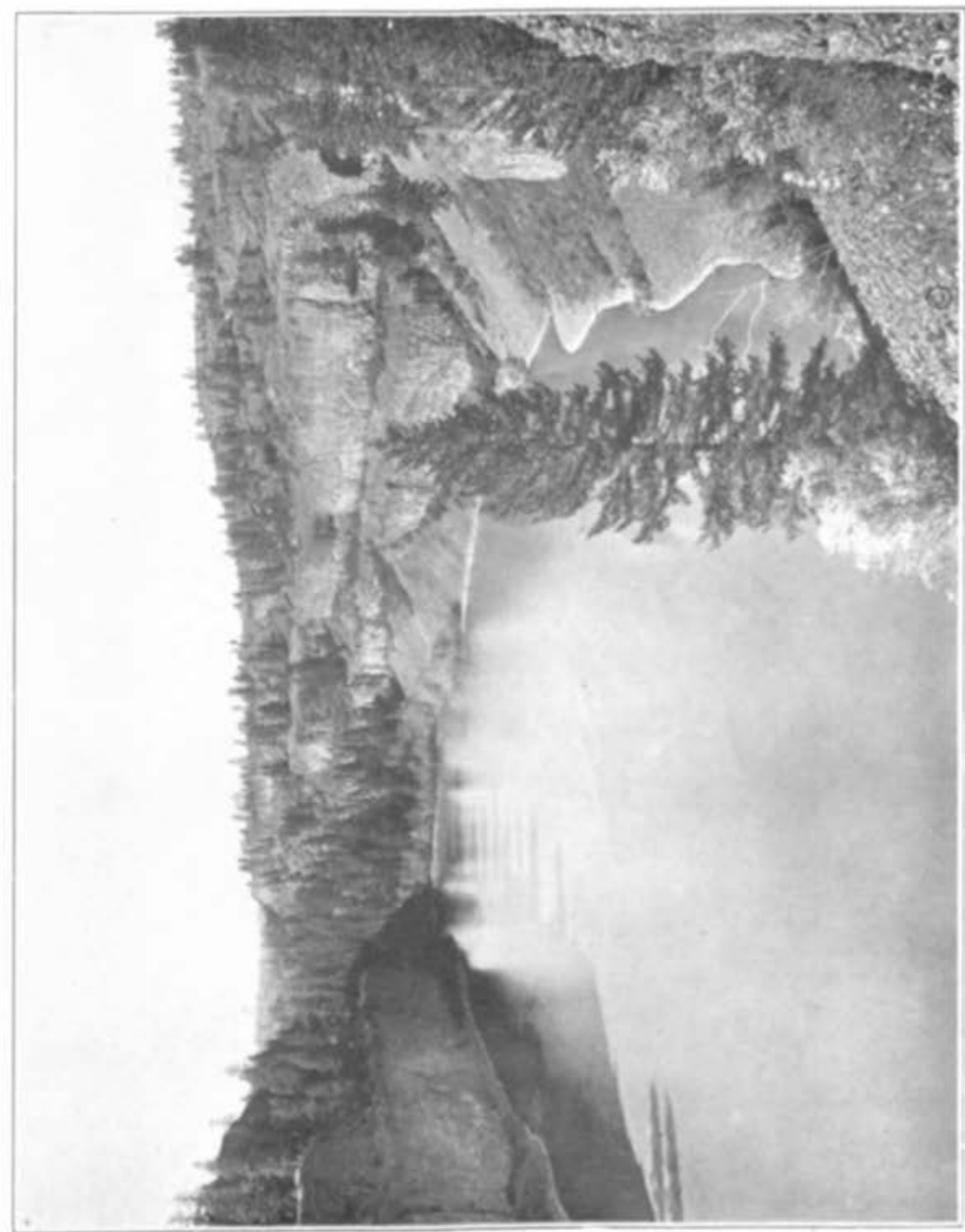




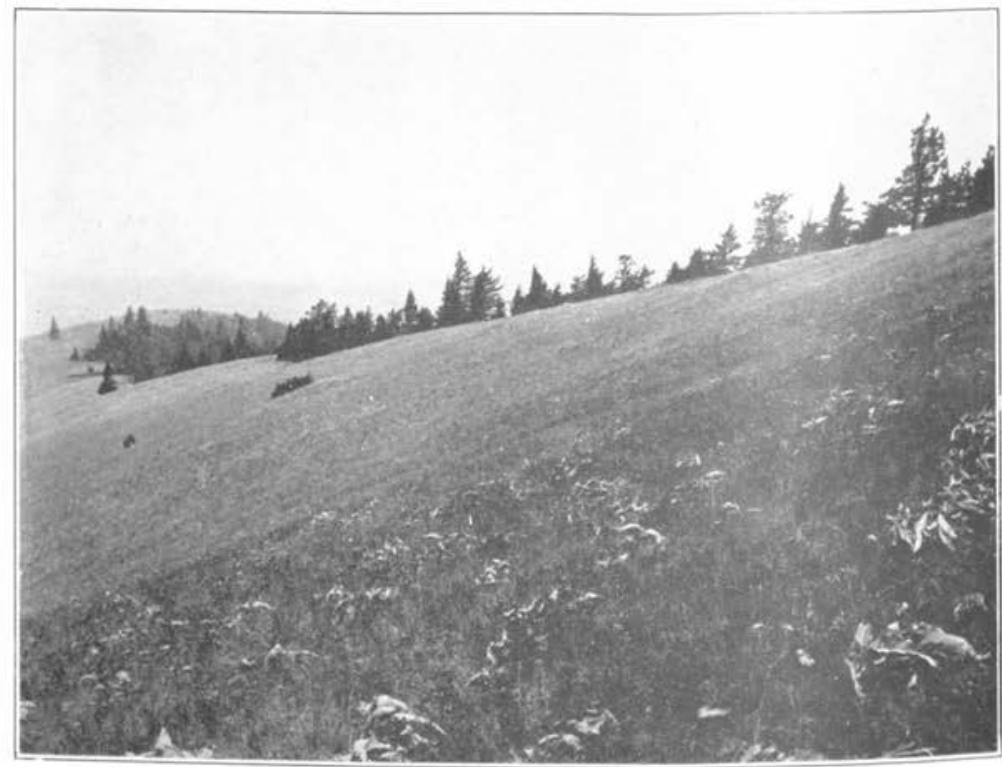

FIG. 46. A sharp ecotone between prairie and forest on a wind-swept slope in Tekoa Mountains.
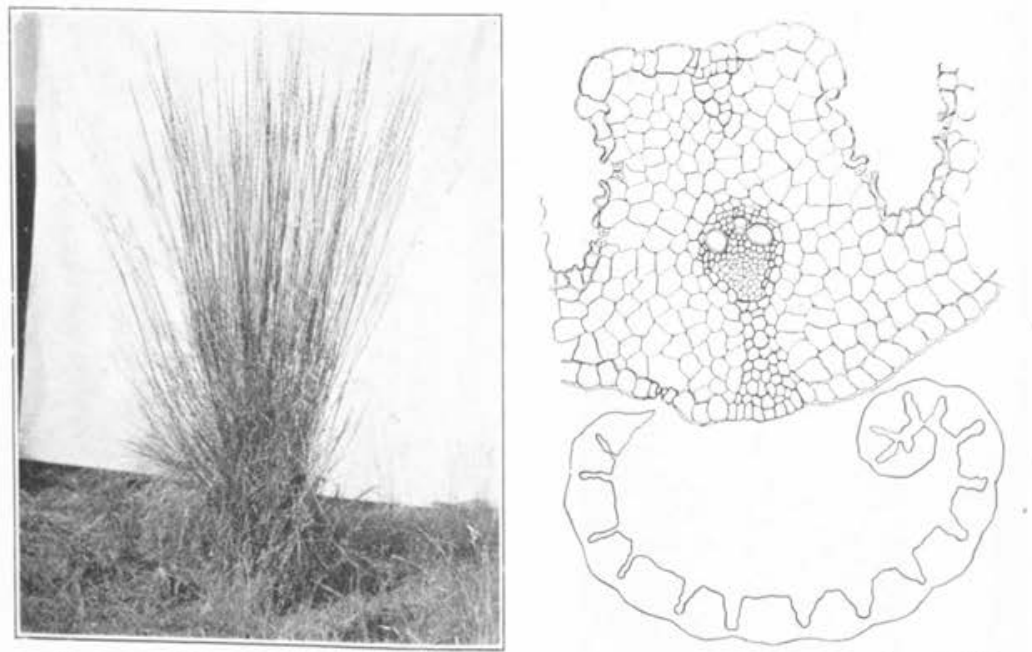

FIG, 47. The bunch-grass, Agropyron spicatum. Diagrammatic crosssection and detailed segment of a leaf showing its xerophytic anatomical structures. 

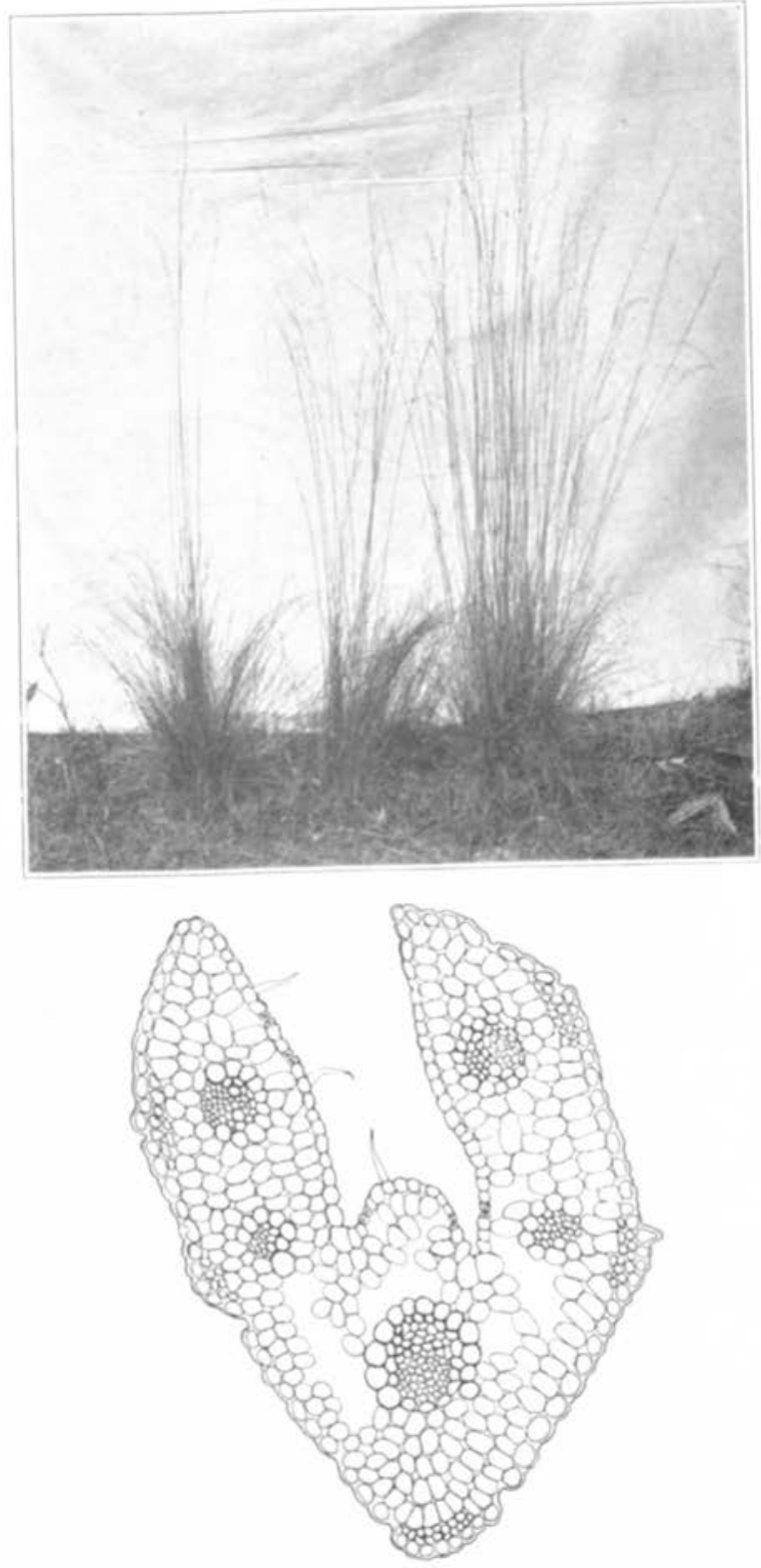

F1G. 48. Bunches of Festuca ovina ingrata. The cross-section of one of the setaceous leaves shows that it is well adapted to endure drought 